\title{
\#USGS
}

\section{Reconnaissance Geologic Map of the Kuskokwim Bay Region, Southwest Alaska}

Including the Bethel, Goodnews Bay, Nushagak Bay, Hagemeister Island, Baird Inlet, Cape Mendenhall, Kuskokwim Bay, Nunivak Island, Saint Matthew, and Pribilof Islands 1:250,000-scale quadrangles

Compiled by Frederic H. Wilson, Chad P. Hults, Solmaz Mohadjer, and Warren L. Coonrad

Pamphlet to accompany

Scientific Investigations Map 3100

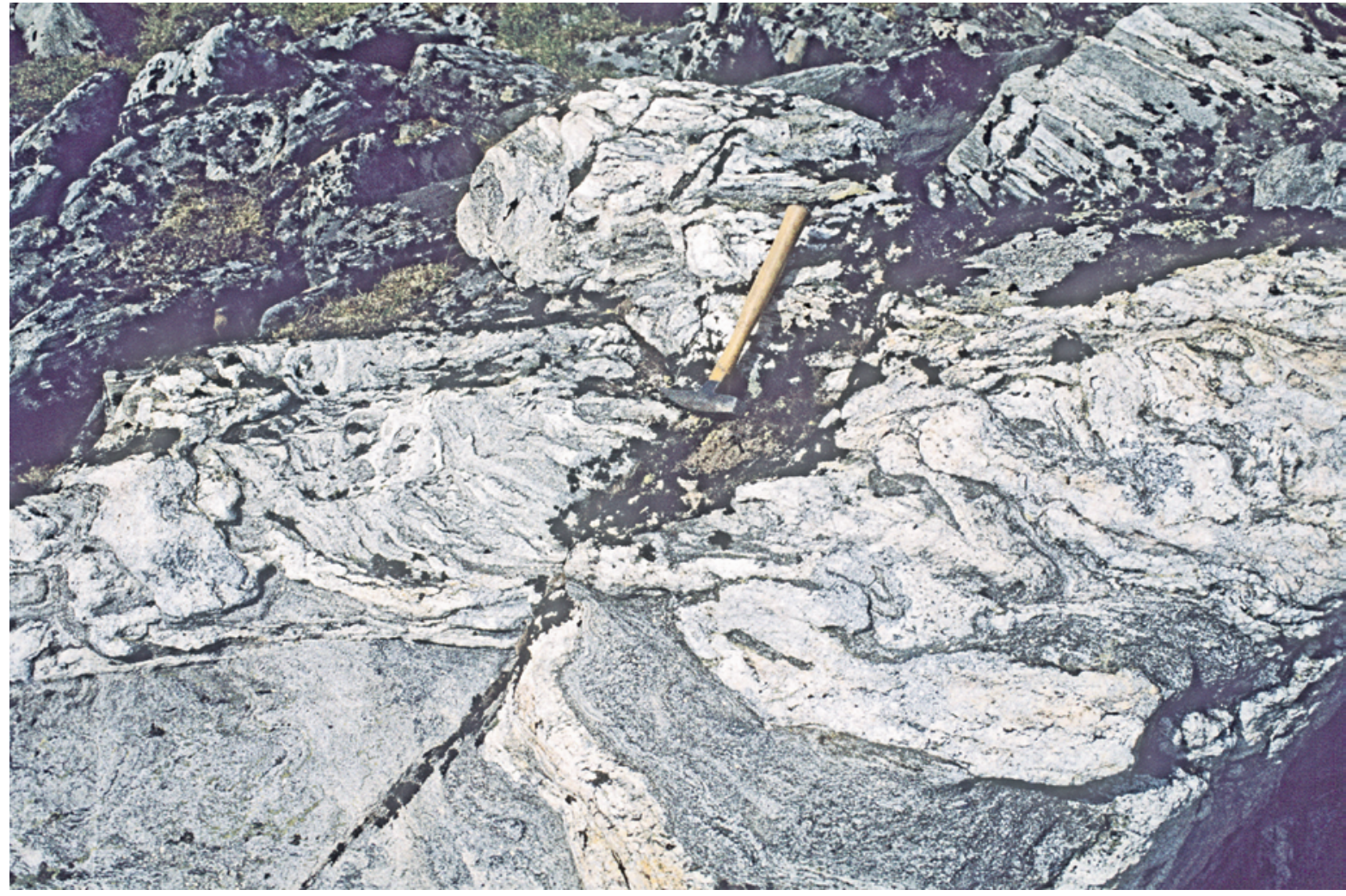

Migmatite north of Thumb Mountain, Goodnews Bay quadrangle. Border phase of plutons in the Kanetktok metamorphic complex. (Photograph by F.H. Wilson, 1975.)

2013

U.S. Department of the Interior

U.S. Geological Survey 



\section{Contents}

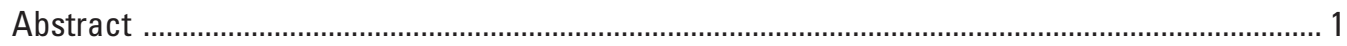

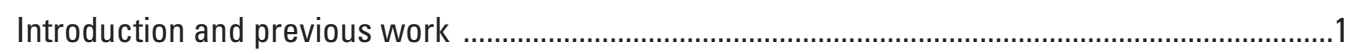

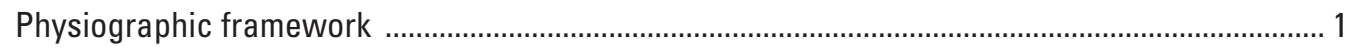

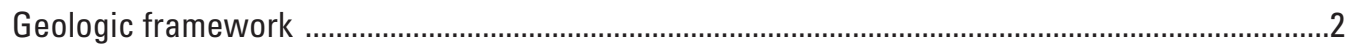

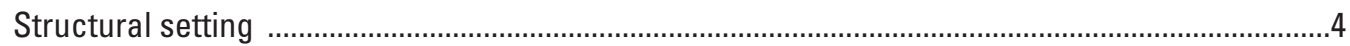

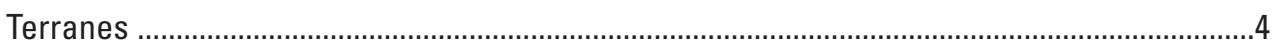

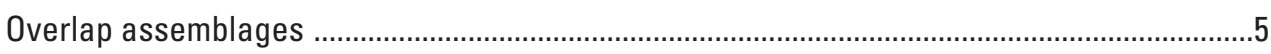

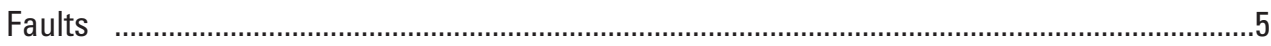

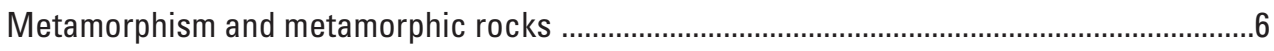

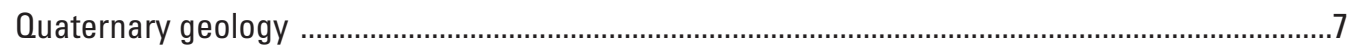

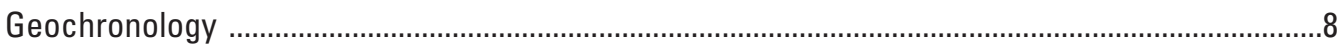

Kanektok metamorphic complex —enigma in southwest Alaska ...................................................

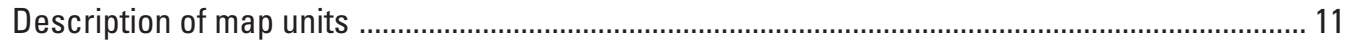

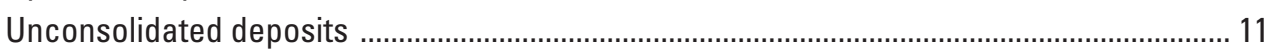

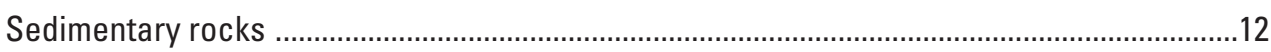

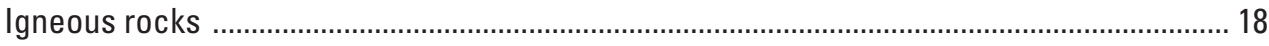

Togiak-Tikchik Complex ..................................................................................................24

Metamorphic rocks of the Togiak-Tikchik Complex ……..............................................27

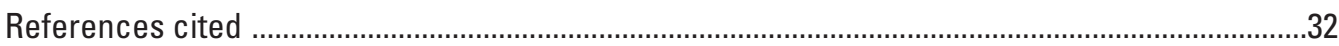

\section{Figures}

Figure 1. Index map showing 1:250,000-scale quadrangle coverage and prominent physiographic features of the map area. ...................................................................................................

Figure 2. Tectonostratigraphic terrane map of southwestern Alaska. .............................................

Figure 3. Gneiss of the Kanektok metamorphic complex (Ek) north of Thumb Mountain. .............10

\section{Tables}

Table 1. Radiometric Ages. 



\section{Abstract}

The rocks of the map area range from Proterozoic age metamorphic rocks of the Kanektok metamorphic complex (Kilbuck terrane) to Quaternary age mafic volcanic rocks of Nunivak Island. The map area encompasses much of the type area of the Togiak-Tikchik Complex. The geologic maps used to construct this compilation were, for the most part, reconnaissance studies done in the time period from the 1950s to 1990s. Pioneering work in the map area by J.M. Hoare and W.L. Coonrad forms the basis for much of this map, either directly or as the stepping off point for later studies compiled here.

Physiographically, the map area ranges from glaciated mountains, as much as 1,500 m high, in the Ahklun Mountains to the coastal lowlands of northern Bristol Bay and the Kuskokwim River delta. The mountains and the finger lakes (drowned fiords) on the east have been strongly affected by Pleistocene and Holocene glaciation.

Within the map area are a number of major faults. The Togiak-Tikchik Fault and its extension to the northeast, the Holitna Fault, are considered extensions of the Denali fault system of central Alaska. Other sub-parallel faults include the Golden Gate, Sawpit, Goodnews, and East Kulukak Faults. Northwest-trending strike-slip faults crosscut and offset northeast-trending fault systems.

Rocks of the area are assigned to a number of distinctive lithologic packages. Most distinctive among these packages are the high-grade metamorphic rocks of the Kanektok metamorphic complex or Kilbuck terrane, composed of a high-grade metamorphic orthogneiss core surrounded by greenschist and amphibolite facies schist, gneiss, and rare marble and quartzite. These rocks have yielded radiometric ages strongly suggestive of a $2.05 \mathrm{Ga}$ emplacement age. Poorly known Paleozoic rocks, including Ordovician to Devonian and Permian limestone, are found east of the Kanektok metamorphic complex. A Triassic(?) ophiolite complex is on the southeast side of Kuskokwim Bay; otherwise only minor Triassic rock units are known. The most widespread rocks of the area are Jurassic and Early Cretaceous(?) volcanic and volcaniclastic rocks. The Kuskokwim Group flysch is restricted largely to the northeast part of the map area. It consists primarily of shelf and minor nearshore facies rocks. Primarily exposed in the lowlands west of the Ahklun Mountains, extensive latest Tertiary and Quaternary alkalic basalt flows and lesser pyroclastic rocks form much of the bedrock of the remaining area. On Saint Matthew Island, Cretaceous volcanic and pyroclastic rocks occur that are not found elsewhere within the map area. The Kuskokwim Group and older rocks, including on Saint Matthew Island, but not the Kanektok metamorphic complex, are intruded by widely dispersed Late Cretaceous and (or) Early Tertiary granitic rocks. Much of the lowland area is mantled by unconsolidated deposits that include glacial, alluvial and fluvial, marine, estuarine, and eolian deposits. These formed during several episodes of Quaternary glaciation.

\section{Introduction and Previous Work}

The map comprises the southwestern-most part of mainland Alaska (fig. 1), exclusive of the Alaska Peninsula, extending from Nushagak Bay on the east to the Saint Matthew and the Pribilof Islands on the west. In general, it is a relatively poorly known region but includes the oldest rocks known in Alaska as well as rocks that are geologically very young. The rocks of the map area range from the Proterozoic metamorphic rocks of the Kanektok metamorphic complex (Kilbuck terrane) to the Quaternary mafic volcanic rocks of Nunivak Island. The map area encompasses much of the type area of the TogiakTikchik Complex.

The geologic maps used to construct this compilation were, for the most part, reconnaissance studies done in the time period from the 1950s to 1990s. A few detailed studies, such as the work of Murphy (1987) or topical studies by Box and others (1990) and Moll-Stalcup and others (1996), provide better control on some aspects of the geology. Pioneering work in the map area by J.M. Hoare and W.L. Coonrad forms the basis for much of this map, either directly or as the stepping off point for later studies. A wide range of sources were used to construct this map, including the published mapping of Barth (1956) in the Pribilof Islands, Coonrad (1957) in the Baird Inlet, Cape Mendenhall, Kuskokwim Bay, and Nunivak Island 1:250,000scale quadrangles, Patton and others (1975) on Saint Matthew Island, Hoare and Coonrad (1959a) and Box and others (1993) in the Bethel 1:250,000-scale quadrangle, and Hoare and Coon$\operatorname{rad}(1961 \mathrm{a}, \mathrm{b} ; 1978)$ in the Goodnews Bay, Nushagak Bay, and Hagemeister Island 1:250,000-scale quadrangles. In addition, we relied on Box (1985a) for revisions to Hoare and Coonrad (1978) in the Hagemeister Island and southern Goodnews Bay 1:250,000-scale quadrangles.

The authors gratefully acknowledge discussions with Steve Box and Sue Karl during map preparation. F. Wilson especially acknowledges the introduction to the area by Warren Coonrad and Joe Hoare during the 1975 field season and Coonrad's continued encouragement and support. Technical review of this map compilation was by Arthur Schultz and Jeanine Schmidt. Map editing was by Theresa Iki.

\section{Physiographic Framework}

The map area encompasses the glaciated Ahklun and Kilbuck Mountains, the coastal lowlands of the southern Kuskokwim River delta and northern Bristol Bay, and a number of large islands in the southern Bering Sea. The Ahklun Mountains range up to $1,500 \mathrm{~m}$ in elevation and form the Ahklun Mountains province of Wahrhaftig (1965). The Ahklun Mountains supported a local ice cap during Pleistocene time that was the source for alpine and large valley glaciers that extended out to sea in Bristol Bay (Kaufman and Manley, 2004; Kaufman and others, 2001a,b; Manley and others, 2001) as well as to the east. The finger lakes of the east side of the map area in WoodTikchik State Park and southward were affected by Pleistocene and Holocene glaciation and are well-developed landlocked 


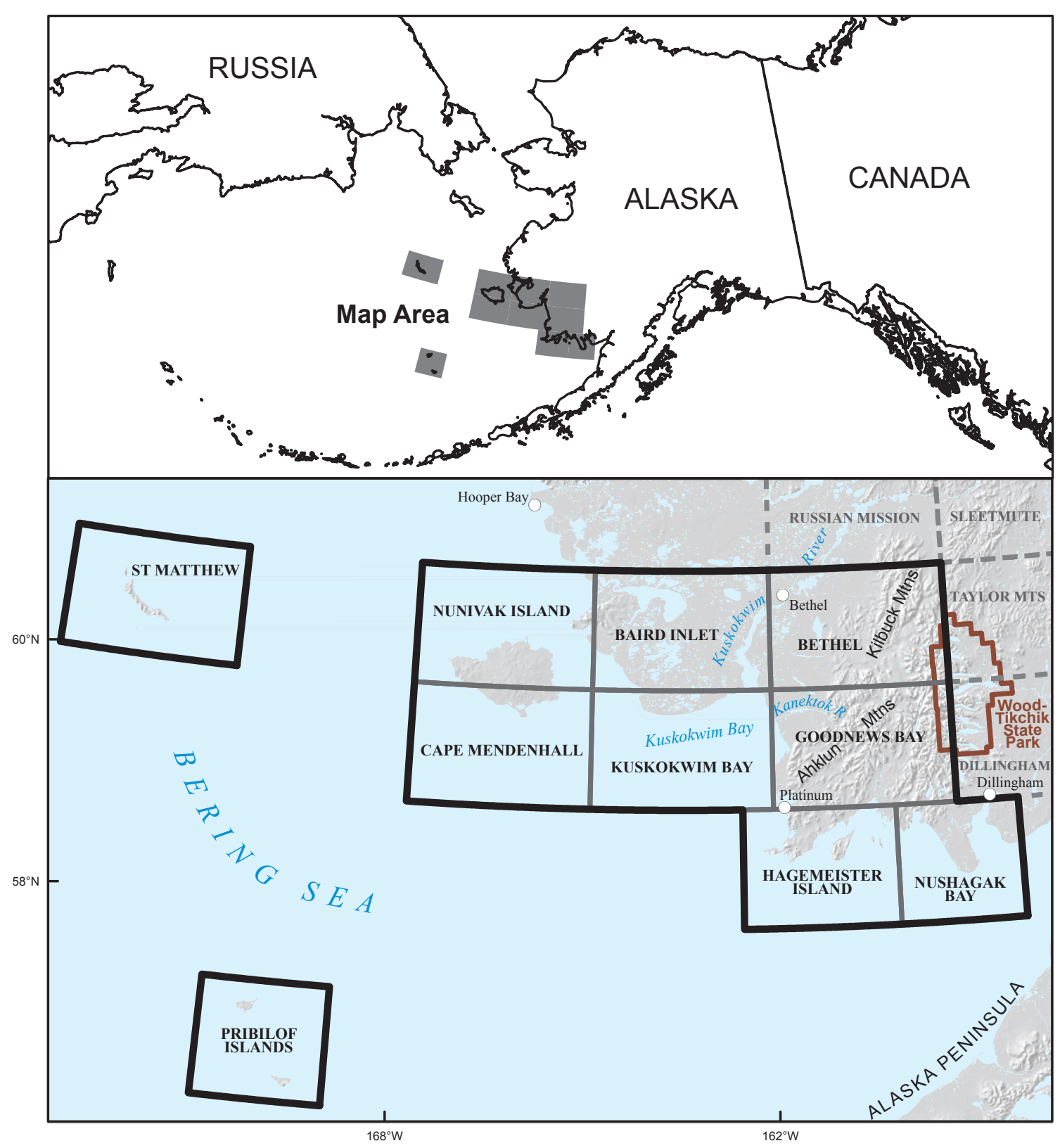

Figure 1. Index map showing 1:250,000-scale quadrangle coverage and prominent physiographic features of the map area.

fiords. West of the Ahklun Mountains, the southern part of the Kilbuck Mountains range up to 1,150 m high and lie in Wahrhaftig's Kuskokwim Mountains section of the Western Alaska province (Wahrhaftig, 1965). Although remnant cirque glaciers occur locally in the Ahklun Mountains, only weathered cirques indicate past glaciation in the Kilbuck Mountains. Farther west are the marshy, lake-covered lowlands of northern Bristol Bay and the Kuskokwim River delta in Wahrhaftig's Yukon-Kuskokwim Coastal Lowland section of the Bering Shelf province (Wahrhaftig, 1965). Glacial deposits are an important component of the unconsolidated deposits of this part of the map area; however, the dominant topographic features are the geologically young basaltic cinder cones and flows of the lowland and the volcanic islands rising from Wahrhaftig's (1965) Bering Platform section of the Bering Shelf province. Nelson Island and Saint Matthew Island expose older rocks in the only other topographic high points of the western part of the map area. Permafrost is sporadic to discontinuous throughout the map area (Wahrhaftig, 1965) and both permafrost and the cirque glaciers are melting as a result of current climate conditions.

\section{Geologic Framework}

The map area contains a number of distinctive lithologic packages. We did not assign units to terranes because the area remains a region of reconnaissance-scale mapping and poor age control. However, in a section below we provide a summary of descriptions of the terrane assignments others have made. 
A significant geologic feature of the region is the Proterozoic, possibly Paleoproterozoic, Kanektok metamorphic complex of Hoare and Coonrad (1979), also known as the Kilbuck terrane of Jones and others (1981). Exposed at the western edge of the mountains north of Goodnews Bay, this high-grade metamorphic complex is composed of an orthogneiss core metamorphosed to granulite facies surrounded by greenschist and amphibolite facies schist, gneiss, and rare marble and quartzite (Turner and others, 2009) and may include some of the oldest rocks in Alaska. A more complete discussion of the Kanektok metamorphic complex is provided in a section below.

A variety of poorly known Paleozoic rocks, including Ordovician to Devonian and Permian limestone, crop out east of the Kanektok metamorphic complex. These rocks are included in a complex structural assemblage of Paleozoic and Mesozoic volcanic and sedimentary rocks and mélange traditionally assigned to the Gemuk Group (Hoare and Coonrad, 1959a; 1961a,b). The Gemuk Group was originally loosely defined in the 1950s in the northwestern Taylor Mountains quadrangle and southward (Cady and others, 1955); subsequently its areal extent was expanded by Hoare and Coonrad (1959a,b; 1961a,b) and through unpublished mapping of J.N. Platt in the Taylor Mountains and J.N. Platt and E.H. Muller in the Dillingham 1:250,000-scale quadrangles in the late 1950s era. The Gemuk Group came to include many rocks ranging in age from Paleozoic to Cretaceous in southwest Alaska. Wilson and Coonrad (2005) discussed the history of usage of the term Gemuk Group and formally abandoned the Gemuk Group as a stratigraphic unit and term. Many of the rocks that were traditionally included in this unit are now assigned to the Togiak-Tikchik Complex. Within the map area, rocks that range in age from early Paleozoic to Cretaceous are included in the Togiak-Tikchik Complex structural assemblage. Box and others (1993) subdivided these rocks into a series of lithologic units in the Bethel quadrangle and Wilson and others (2006b) created similar subdivisions in the Taylor Mountains and Dillingham quadrangles to the east. However, other than the few subdivisions made of the MzPz unit by Hoare and Coonrad (1978), similar subdivisions have not been made here for the rocks in the Goodnews Bay quadrangle. However, reexamination of available data, especially the field notes of J.M. Hoare, W.L. Coonrad, W.H. Condon, and others, may allow some subdivision in the future. Among the rocks assigned to the Togiak-Tikchik Complex in the Bethel quadrangle are metamorphic rocks of unknown protolith age that locally yield Jurassic metamorphic ages. Jones and Silberling (1979), Jones and others (1981), Box (1985a), and Decker and others (1994) assigned the rocks of the Gemuk Group (now Togiak-Tikchik Complex) largely to the Goodnews terrane; some were also assigned to the Togiak terrane. Box and others (1993) interpreted these Mesozoic and Paleozoic rocks as an accretionary complex that progressively underthrust the volcanic arc rocks to the east.

At Cape Newenham, between Kuskokwim and Togiak Bays, a Triassic(?) ophiolite complex is associated with mafic and ultramafic intrusive rocks of possible Jurassic age in a complex structural relation, otherwise only minor Triassic rock units are known in the map area. The Jurassic ultramafic rocks were the source for the platinum group metals of the only commercial platinum deposit in Alaska (Hudson, 2001).

The eastern part of the map area consists largely of Triassic(?), Jurassic, and Early Cretaceous(?) volcaniclastic sedimentary rocks assigned to the Togiak terrane by Box (1985a), Box and others (1993), and Decker and others (1994). Wilson and others (2006b) suggested that these rocks may correlate in part with the lithologically similar Koksetna River sequence of Wallace and others (1989), exposed west of the Alaska-Aleutian Range. The two packages of rocks may represent the east and west sides of a Jurassic basin. The Kilbuck Mountains in the north-central Bethel quadrangle also consist largely of Jurassic and Early(?) Cretaceous volcaniclastic sedimentary rocks, but also include Middle Jurassic andesite and basalt flows and aquagene tuff (Box and others, 1993). These rocks in the Bethel quadrangle have been assigned to the Nyac terrane (Box and others, 1993; Decker and others, 1994) and are considered in part distinctive because they are intruded by mid-Cretaceous plutons, such as the Nyac pluton, which are not known to intrude rocks assigned to any other terrane in southwest Alaska. However, these Nyac terrane rocks are poorly known. Some Jurassic fossils have been collected. A number of igneous intrusive complexes that intrude the Nyac terrane are undated; Box and others (1993) assigned these complexes an early Tertiary to Jurassic age range.

Four distinctive sequences of Lower Cretaceous sedimentary rocks overlie the older rocks of the Ahklun Mountains. All of Valanginian age, each sequence has a slightly different mix of lithologies and character. The graywacke of Buchia Ridge (Hoare and Coonrad, 1983) is a fining upward clastic sequence rich in Buchia in its lower part and present in a largely undeformed state in a thrust sheet. West of Buchia Ridge, the limy grit and limestone of the Ungalikthluk belt of Hoare and Coonrad (1983) contains lithic clasts of low-grade metamorphic rocks. Farther west, volcanic and sedimentary rocks of the Mount Oratia belt of Hoare and Coonrad (1983) is a multi-hued package of widely varying lithology that includes chert, graywacke, andesitic crystal-lithic tuff and a few flows. Rocks of the Mount Oratia belt rocks overlie the Togiak-Tikchik Complex. The calcareous graywacke and siltstone of the Eek Mountains belt of Hoare and Coonrad (1983) is the westernmost of the four sequences. The sequence consists of strongly folded and commonly overturned calcareous turbidities of presumed Valanginian age and contains lithic clasts that include metamorphic rocks presumed to be of the Kanektok metamorphic complex (Hoare and Coonrad, 1983).

The Kuskokwim Group, an Early (Albian(?)) and Late Cretaceous flysch is restricted largely to the northeast part of the map area, although it is widely distributed throughout southwest Alaska. The Kuskokwim Group consists largely of interbedded graywacke and shale and, locally, has interbeds of argillite and conglomerate (Cady and others, 1955). In the map area, it consists largely of shelf facies rocks, although nearshore facies conglomeratic rocks are found in the vicinity of the Kanektok metamorphic complex rocks. Box and others (1993) considered the conglomeratic rocks, which include clasts probably derived from the Kanektok metamorphic complex, to be a basal facies of the Kuskokwim Group. 
Widely dispersed latest Cretaceous and (or) early Tertiary granitic rocks intrude the Kuskokwim Group and most of the older rocks, but do not intrude the Kanektok metamorphic complex (Patton and others, 1975; Wilson, 1977; Hoare and Coonrad, 1978; Box and others, 1993). The plutons yield ages between approximately 60 and $70 \mathrm{Ma}$ and show a crude compositional zoning. The more mafic plutons tend to occur in the western part of the map area, whereas more potassium-rich plutons tend to occur in the eastern part of the map area and farther eastward in the Dillingham quadrangle (Wilson, 1977; Wilson and others, 2006b). The plutons are conspicuously absent in the Kanektok metamorphic complex. Northwest of the Kanektok metamorphic complex, a number of plutons of unknown age intrude the Jurassic volcanic and volcaniclastic rocks of the Nyac terrane of Jones and others (1981) and Box and others (1993). Some of the plutons associated with the Nyac terrane may include latest Cretaceous to early Tertiary plutons, but they may also include plutonic rocks as old as Jurassic. Within the region, the rocks of the Nyac terrane are the only rocks intruded by plutons of mid-Cretaceous ( 110 to $\sim 120 \mathrm{Ma})$ age.

Extensive latest Tertiary and Quaternary alkalic basalt flows and lesser pyroclastic rocks form much of the bedrock of the western part of the map area. Primarily exposed in the lowlands west of the Ahklun Mountains, these volcanic rocks are also well known from Nunivak Island and the Pribilof Islands as well as north of Togiak Bay in the eastern part of the map area. The volcanic rocks are part of a belt of alkalic basalt that is widely distributed in western Alaska as far north as the Seward Peninsula. The rocks of Nunivak Island and the Pribilof Islands were extensively sampled for paleomagnetic analysis and radiometric age determination (Cox and Dalrymple, 1967; Cox and others, 1966) and these analyses were used to help establish the geomagnetic time scale of Cox and others (1968). In addition, xenoliths from the basalt of Nunivak Island have been the subject of a number of studies (see for example, Hoare and Condon, 1973; Francis, 1976; Roden and others, 1980).

Cretaceous volcanic and pyroclastic rocks that are exposed on Saint Matthew Island are not separately mapped elsewhere within the map area. However, rocks of this age may be present within other map units of the mainland. In the westernmost part of the map area, the largely volcanic and intrusive rocks of Saint Matthew Island (Patton and others, 1975) and Saint Lawrence Island to the north (Patton and Csejtey, 1979) provide the only exposures of the older rocks of the Bering Sea shelf.

Glacially derived materials are a major component of the unconsolidated deposits in the eastern part of the map area and are readily apparent glacial landforms. At maximum Pleistocene glaciation, glaciers flowing east from the Ahklun Mountains merged with glaciers flowing from the Alaska-Aleutian Range to the east. West of the Ahklun and Kilbuck Mountains, much of the map area consists of Quaternary surficial deposits of the Kuskokwim River delta. Largely not subdivided, these surficial deposits are thought to include glacial deposits of late Wisconsin and older age (W.L. Coonrad, oral commun., 2001) and uplifted marine deposits. W.L. Coonrad (oral commun., 2001) reported glacial deposits in stream and river cutbanks well away from the mountains in the Kuskokwim River delta lowlands. Small alpine glaciers remain in the higher mountains of the region.

\section{Structural Setting}

\section{Terranes}

The rocks in the Ahklun and Kilbuck Mountains area were mapped as a series of overlapping terranes and subterranes in the 1980s and 1990s by Jones and others (1981) and subsequently by S.E. Box and coworkers (Box, 1985a,b; Box and others, 1993; Decker and others, 1994). Decker and others (1994) summarized the application of terrane terminology to the region, dividing the map area into the Nyack ${ }^{1}$, Togiak, Goodnews, and Kilbuck terranes (fig. 2). However, it must be recognized that development of terrane terminology for this region preceded detailed geologic mapping; as a result, some of the map units shown on the geologic map may occur in more than one terrane.

Many of these terranes reflect various components of an accretionary arc system. However, the most distinct of the terranes is the Kilbuck terrane, which is synonymous with the Kanektok metamorphic complex. This is the sole terrane of the region not thought to reflect an accretionary arc. It can be described as multiply deformed, upper amphibolite to granulite facies metamorphic rocks and is thought to represent a fragment of continental crust of unknown affinity. It is also the only terrane not intruded by younger (late Mesozoic or Cenozoic) plutons. The Togiak terrane, the largest single terrane fragment in the map area, includes many of the rocks of the eastern part of the Goodnews Bay and Bethel quadrangles, much of the Hagemeister Island quadrangle, and all of the Jurassic-age stratified bedrock of the Nushagak Bay quadrangle. The East Kulukak Fault divides the Togiak terrane into two subterranes. According to Decker and others (1994, p. 293), the subterranes "differ in sedimentary facies and structural style, but are linked by common provenance and stratigraphic history." The larger Hagemeister subterrane is thought to be an Upper Triassic to Lower Cretaceous volcanic island arc built upon an Upper Triassic ophiolitic basement. The Kulukak subterrane consists primarily of Jurassic volcaniclastic turbidites; although Box (1985a) suggested a provenance link with the Hagemeister subterrane, according to Decker and others (1994), no direct depositional relation has been observed.

"The Goodnews terrane is a collage of variably metamorphosed blocks of laminated tuff, chert, basalt, graywacke, limestone, gabbro, and ultramafic rocks, in roughly that order of abundance" (Decker and others, 1994, p. 295). The Goodnews terrane includes, generally in fault-bounded blocks, Devonian to Ordovician, Permian, and Triassic limestone and early Paleozoic, Triassic, and Jurassic chert. Jones and Silberling (1979) defined the Tikchik terrane, which became one of three subterranes included in the Goodnews terrane by Box (1985a) and one of four subterranes of the Goodnews terrane by Decker and others (1994). The Tikchik terrane consists of a mélange of Paleozoic and Mesozoic chert, Permian limestone and clastic rocks, Permian or Triassic(?) pillow basalt, and Late Triassic rocks (Decker and others, 1994). The Cape Pierce subterrane is described

\footnotetext{
${ }^{1}$ The generally accepted spelling for the community that this terrane is named after is Nyac (Orth, 1967).
} 
as "foliated metamorphic rocks $* * *$ probably derived from protoliths of probable Permian and Triassic ages" (Box, 1985a). Unfortunately, the description in Decker and others (1994) is not clear, but it seems that the Cape Pierce subterrane may include the Triassic ophiolitic rocks upon which the volcanic arc of the Togiak terrane was built. The Platinum subterrane is variably described as Lower and Middle Jurassic nonfoliated mafic flows, tuff, and volcaniclastic rocks, apparently containing interbedded calcareous tuff having Permian fossils or as the nonfoliated and less deformed equivalent of the lowest schistose nappe of the Permian to Triassic Cape Pierce terrane (Decker and others, 1994). Clearly, there is an internal conflict in the definition of the subterrane; what is known for both of these subterranes is that they are intruded by zoned ultramafic bodies of presumed Jurassic age. The Platinum subterrane includes two of the Permian map units (Pv, Pvs) which we assign to the Togiak-Tikchik Complex. The Nukluk and Tikchik subterranes are similar in that both are structurally disrupted units or mélanges that contain blocks ranging in age from early Paleozoic to Jurassic or Early Cretaceous. The blocks include chert and limestone (units Kvs, Pls), clastic sedimentary rocks (unit Pcs), and Permian and Triassic volcanic rocks (units Pv, Kv). However, the Tikchik subterrane is spatially separated from the other parts of the Goodnews terrane; the Togiak terrane lies between the Tikchik subterrane and the rest of the Goodnews terrane.

The Nyac terrane is found in the Bethel quadrangle along the northwest part of the bedrock outcrop belt. Poorly defined, the Nyac (Nyack) terrane is thought to consist of an arc-related Jurassic volcanic and volcaniclastic rock assemblage (Decker and others, 1994). The Golden Gate Fault separates the Nyac and Kilbuck terranes where exposed. The Nyac terrane is distinctive in that it is the only terrane of the region intruded by mid-Cretaceous-age plutons.

The terrane nomenclature for this region is in need of revision as shown by the data and information used to create the present compilation. More detailed mapping and studies of the rock units will help to better define the appropriate packages and will better define the appropriate bounding structures. Paleontological and detrital zircon studies will help to better understand the affinities of the mapped rock units.

\section{Overlap Assemblages}

A number of Cretaceous sedimentary packages occur as overlap assemblages on the terranes. The oldest of these assemblages are of Valanginian age and occur in four belts of common age but distinctive lithology. The graywacke of Buchia Ridge (Kgbr) and the Ungalikthluk (Klg) belt of Hoare and Coonrad (1983) overlap the Togiak terrane, whereas the Mount Oratia (Kvm) and Eek Mountains (Kcgc) belts of Hoare and Coonrad (1983) overlap the Goodnews terrane. Rocks of the Eek Mountains belt include high-grade metamorphic clasts apparently derived from the Kanektok metamorphic complex.

A younger overlap assemblage, the Kuskokwim Group (Kk), a largely Late Cretaceous sedimentary unit, is widespread in southwest Alaska. In the map area, the Kuskokwim Group overlaps both the Goodnews and Kilbuck (Kanektok metamor- phic complex) terranes. It locally underlies the Kilbuck terrane as well; Kuskokwim Group rocks crop out along the Kanektok River where the river cuts through the metamorphic complex that forms the ridges above.

The Summit Island Formation in the southern part of the map area is the youngest of the overlap assemblages. Apparently deposited in two adjacent(?) basins, the Summit Island Formation overlaps the Togiak terrane.

Latest Cretaceous or earliest Tertiary plutonic rocks intrude all terranes east of the Kilbuck terrane; plutonic rocks of this age are conspicuously absent west of the terrane boundary. As mentioned earlier, within the map area mid-Cretaceous plutonic rocks have been found only in the Nyac terrane.

\section{Faults}

Faults are mapped throughout the map area. One of the major faults, the Holitna Fault, enters the map area from the northeast and is considered part of the Denali-Farewell Fault System of southern Alaska. The Holitna Fault has a trace that cuts surficial deposits indicating it is presently active (Cady and others, 1955; F.H. Wilson, unpub. data). Field maps from the 1969 and 1970 seasons of J.M. Hoare and W.H. Condon (unpub. data) indicate northwest side up and right-lateral offset. Cady and others (1955) indicated that the Holitna Fault had a highangle reverse sense of motion. The Holitna Fault is generally linked with the Togiak-Tikchik and Hagemeister Faults (Hoare and Coonrad, 1978), which strike offshore into Bristol Bay.

Other sub-parallel faults, such as the Golden Gate (Hoare and Coonrad, 1959a), Goodnews, and East Kulukak Faults (Hoare and Coonrad, 1978) provide strong evidence for a northeast-trending structural grain and are in some cases considered terrane-bounding faults (see Box and others, 1993; Decker and others, 1994). The Golden Gate Fault generally trends parallel to the Denali-Farewell Fault System and passes through the western Bethel quadrangle. The Golden Gate Fault is a highangle reverse fault dipping steeply to the southeast. A number of northwest-trending faults crosscut and offset rock units and the northeast-trending faults. Key among these northeast-trending faults are the Mount Oratia and Fork (or Lake) Creek high-angle reverse faults that are cut by the Trail Creek strike-slip fault of Hoare and Coonrad (1978); each of these northwest-trending faults follows topographic lineaments along which the rocks on either side generally indicate left-lateral offset. For example, the northwest-trending Trail Creek Fault appears to have 10 to 15 $\mathrm{km}$ of left-lateral strike-slip movement.

Thrust and high-angle reverse faults are an important structural feature in the map area; however, as will be discussed more fully in the discussion of the Kanektok metamorphic complex rocks, agreement between the available map sources is limited at best. Box (1985a) mapped a complex system of thrust faults and folded thrust faults cutting Mesozoic rock units between Kuskokwim and Togiak Bays. While these faults are shown here as "thrusts", the rock units separated by these faults have many common characteristics and the faults commonly emplace younger over older rocks. 


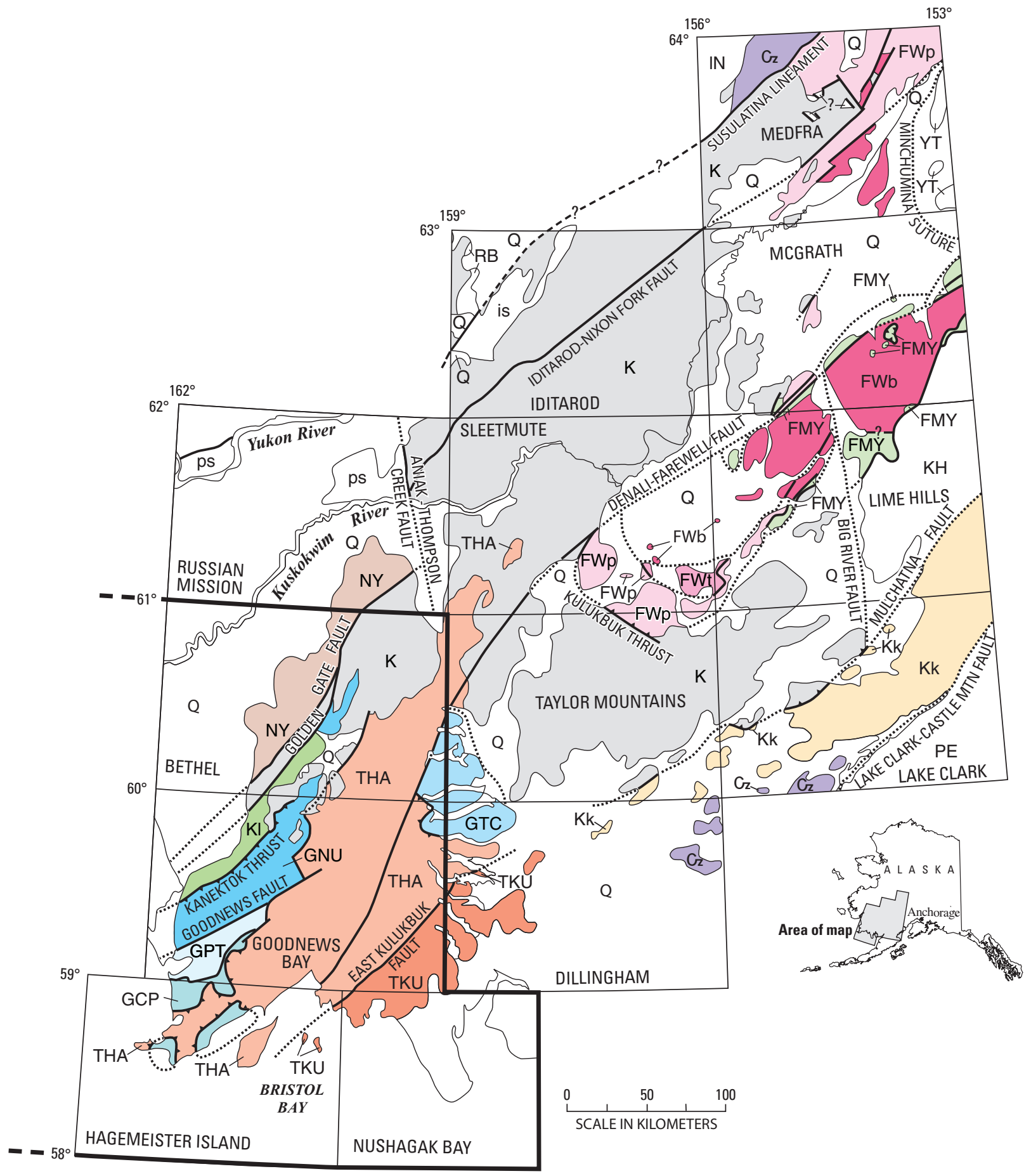

Figure 2. Tectonostratigraphic terrane map of southwestern Alaska, (from Decker and others, 1994). The included part of the Kuskokwim Bay region map area is shown outlined in black. See map explanation on facing page.

\section{Metamorphism and Metamorphic Rocks}

Description of the metamorphic character of the rocks of the region, such as facies and grade, is incomplete at best. Although poorly known, the most thorough descriptions have been made for the Kanektok metamorphic complex, described later. Available descriptions indicate that many of the rocks of the Bethel quadrangle have undergone low-grade metamorphism, whereas the rocks of the Kisaralik Anticlinorium of
Box and others (1993) in the north-central Bethel quadrangle are metamorphosed to greenschist and transitional greenschistblueschist facies. Similarly, metamorphic rocks in the vicinity of Goodnews Bay (see "Metamorphic Rocks of the TogiakTikchik Complex" section in the Description of Map Units) also are metamorphosed to greenschist and transitional greenschistblueschist facies. Deformation of rock units is even less well described; where data is available, it is included in the applicable unit description. 


\begin{tabular}{|c|c|}
\hline & $\begin{array}{l}\text { EXPLANATION } \\
\text { VERLAP ASSEMBLAGES }\end{array}$ \\
\hline Q & Quaternary Surficial Deposits \\
\hline K & Kuskokwim Group \\
\hline $\mathrm{Gz}$ & Cenozoic Deposits \\
\hline TERRA & VES OF SOUTHWEST ALASKA \\
\hline Alaska $\mathrm{R}$ & ange and Kuskokwim Mountains \\
\hline Fare & well Terrane \\
\hline FMY & Mystic Sequence \\
\hline Whi & e Mountain Sequence \\
\hline $\mathrm{FWb}$ & Basinal Facies \\
\hline FWt & Transitional Facies \\
\hline FWp & Platform Facies \\
\hline Bristol B & ay Region \\
\hline NY & Nyack Terrane \\
\hline Togi & k Terrane \\
\hline THA & Hagemeister Subterrane \\
\hline TKU & Kulukak Subterrane \\
\hline Goo & news Terrane \\
\hline GNU & Nukluk Subterrane \\
\hline GTC & Tikchik Subterrane \\
\hline GPT & Platinum Subterrane \\
\hline GCP & Cape Pierce Subterrane \\
\hline $\mathrm{KI}$ & Kilbuck Terrane \\
\hline & ADJACENT TERRANES \\
\hline $\mathrm{KH}$ & Northern Kahiltna Terrane \\
\hline Kk & Southern Kahiltna Terrane \\
\hline $\mathrm{PE}$ & Peninsular Terrane \\
\hline IN & Innoko Terrane \\
\hline RB & Ruby Terrane \\
\hline YT & Yukon-Tanana Terrane \\
\hline UNITS OF & JNCERTAIN TERRANE AFFINITY \\
\hline is & Idono Sequence \\
\hline ps & Portage Sequence \\
\hline 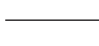 & Contact \\
\hline$-?--$ & $\begin{array}{l}\text { Fault_-Dashed where approxin } \\
\text { where concealed; queried }\end{array}$ \\
\hline & $\begin{array}{l}\text { Thrust fault-Dotted where c } \\
\text { Sawteeth on upper plate }\end{array}$ \\
\hline
\end{tabular}

A distinctive sequence of lithologic units is exposed on a ridge in the Kilbuck Mountains just east of Greenstone Ridge in the Bethel quadrangle. These rocks were originally mapped by Hoare and Coonrad (1959a) as part of the Gemuk Group surrounded by rocks of the Kuskokwim Group. Box and others (1993) recognized the rocks as an antiformally folded structural sequence of variably metamorphosed rocks that they informally referred to as the Kisaralik anticlinorium. The anticlinorium is cored by a structurally imbricate package of Mesozoic to Paleozoic deep-marine sedimentary and mafic volcanic rocks (Box and others, 1993). The folding that created the anticlinorium also folded the rocks of the Kuskokwim Group nearshore facies (Kkn) that unconformably overlie the Mesozoic to Paleozoic core (Box and others, 1993). Deformation and metamorphic grade decrease structurally downward through the structural package. In structural order from top to bottom, map units $\mathrm{M}_{2} \mathrm{P}_{2} p, \mathrm{MDm}$, and $\mathrm{MzP}_{2} \mathrm{~m}$ are strongly foliated and are metamorphosed to greenschist and transitional greenschist-blueschist facies, whereas lower units in the anticlinorium, MzPs, $\mathrm{MzPz}, \mathrm{MzP}_{z}$, have a slaty cleavage and are metamorphosed to prehnite-pumpellyite facies (Box and others, 1993). Units are separated by antiformally folded low-angle faults (Box and others, 1993). Units making up the Kisaralik anticlinorium were included in the Goodnews terrane by Box and others (1993). Box and others (1993) used the basal conglomerate of the Kuskokwim Group, which they reported as Late Cretaceous (Cenomanian(?)) in age, to constrain the younger age limit of these map units. However, fossils of Albian (late Early Cretaceous) age are reported by Murphy (1987) for this map unit (Kkn).

\section{Quaternary Geology}

The Kuskokwim Bay region has a rich Quaternary geologic history of mafic volcanism, glacial advances, eolian deposition, varying sea level, and the development of periglacial features. Detailed mapping of surficial geology has not been undertaken, except for the mafic volcanic rocks on Nunivak Island and the Pribilof Islands (Cox and others, 1966; 1968; Hoare and others, 1968); in much of the map area surficial deposits are not subdivided. A number of topical studies by Kaufman and co-workers (Kaufman and Manley, 2004; Kaufman and others, 2001a, 2003; Manley and others, 2001; Levy and others, 2004) and Lea and co-workers (Lea, 1989; Lea and Waythomas, 1990; Lea and others, 1991) have begun establishment of a framework for the Quaternary history and stratigraphy of the map area. In particular, Lea (1989) defined a number of formal and informal stratigraphic units and type sections in the southeast part of the map area. However, to date, maps showing the distribution of these units have not been produced.

Within the map area, glacial deposits range from Holocene to an indeterminate Pleistocene age. The oldest of the deposits form the informally defined Nichols Hills drift of Lea (1989) on the Nushagak Peninsula. These deposits are undated and designated oldest because they stratigraphically underlie better defined deposits of the Nushagak Formation and lie outboard of glacial deposits that still retain some of their original morphology. The Nichols Hills drift, according to Lea $(1989$, p. 88) may overlie a still older diamicton exposed at Cape Constantine reported by W.L. Coonrad (oral commun. to P.D. Lea, 1982). 
Overlying the Nichols Hills drift are the deposits of the Nushagak Formation. This unit, originally called the Nushagak beds by Spurr (1900) and formalized as the Nushagak Formation by Mertie (1938), was originally designated as Pliocene or Miocene age and thought to represent nearshore marine deposits. However, re-examination of the type area by Lea (1989) indicates that the deposits are proglacial intertidal and fluvial sediments. According to Louie Marincovich, Jr., (USGS, oral commun., 1988 ) to Lea (1989, p. 91), the originally reported molluscan fossil assemblage for the formation is now considered to be of Quaternary age. The Nushagak Formation includes morainal deposits designated as the Ekuk moraines, which Lea (1989) tentatively correlated with the Halfmoon Bay drift of Muller (1952). Locally, younger morainal deposits, informally named the Manokotak and Okstukuk moraines, which may record early? Wisconsin and late Wisconsin maxima, are mapped north of Nushagak Bay (Kaufman and others, 2001a,b).

Prior to this map compilation, virtually no maps of surficial deposits west of the Ahklun Mountains existed. W.L. Coonrad (USGS, oral commun., 2002?) reported the presence of glacial deposits in river cuts in the Yukon Kuskokwim Coastal Lowland section of the Bering Shelf province of Wahrhaftig (1965). Hoare and Coonrad (1959a, 1961b) showed a reconnaissance-level subdivision of surficial deposits in the Bethel and Goodnews Bay quadrangles and, where possible, that map data is shown here. We show a reconnaissance-level subdivision of surficial deposits in the Baird Inlet and Kuskokwim Bay quadrangles on the basis of topography and surface character. In the Nushagak Bay quadrangle, unpublished mapping of W.L. Coonrad in the northern part of the quadrangle was extended southward based on W.L. Coonrad's field sheets and our topographic interpretation.

\section{Geochronology}

There is a long history of geochronologic studies in the map area, yet coverage of geologic units remains scant and data interpretation, particularly on the older rock units (table 1) is open to some controversy.

More than $60 \mathrm{~K}$-Ar age determinations on young mafic volcanic rocks on Nunivak Island and the Pribilof Islands were used to provide precise age control for the paleomagnetic time scale developed by Cox, Dalrymple, and Hoare (Cox and Dalrymple, 1967; Hoare and others, 1968; Mankinen and Dalrymple, 1979). During mineral assessment studies of the mid-1970s, $\mathrm{K}-\mathrm{Ar}$ dating plutonic rocks was an emphasis, particularly in the Goodnews Bay and Hagemeister Island quadrangles (Hoare and Coonrad, 1978; Kilburn and others, 1993). Wilson and Smith (1976) provided dates on many of the plutonic rocks of these quadrangles. Box and others (1993) reported K-Ar, ${ }^{40} \mathrm{Ar} /{ }^{39} \mathrm{Ar}$, and $\mathrm{U} / \mathrm{Pb}$ dates on igneous and metamorphic rocks in the Bethel quadrangle including a suite of Early Cretaceous plutons in the northernmost part of the map area. Box and others (1993) also reported fission-track cooling ages on a variety of rocks. Turner and others (1983) reported studies on the Kilbuck terrane rocks in the Goodnews Bay quadrangle; the extensive analytical data for these studies is presented in Turner and others (2009). Other studies (Globerman, 1985; Box, 1985a; Wittbrodt and others, 1989) have added a number of individual dates in parts of the map area, all contributing to understanding of the history of the region.

Dates on most plutonic rocks in the map area yield ages that straddle the Tertiary and Cretaceous boundary (60 to 70 $\mathrm{Ma}$ ). Plutons of this age are widespread throughout much of southwest Alaska. A reverse discordance, in which hornblende consistently yields younger ages than co-existing biotite, is common among the plutonic rocks in the eastern part of the Goodnews Bay quadrangle (Wilson and Smith, 1976). The same reverse discordance is shown by one of the Early Cretaceous plutons in the Bethel quadrangle (Box and others, 1993). This discordance suggests an as yet unexplained problem with the age determinations. In normal conditions, where argon is locked in a mineral as it passes through the blocking temperature, hornblende should yield an older age because it has a higher blocking temperature. The age difference between minerals then would be dependent on the cooling rate.

The main focus of geochronologic studies in the mainland portion of the map area has been on the Kanektok metamorphic complex (fig. 3) or Kilbuck terrane. D.L. Turner and others (2009) measured $77 \mathrm{~K}$-Ar ages on 58 samples of the Kanektok metamorphic complex, as well as dating zircon and sphene by the $\mathrm{U} / \mathrm{Pb}$ method. They also attempted $\mathrm{Rb} / \mathrm{Sr}$ geochronology with limited success. Extensive dating of the Kanektok metamorphic complex yielded widely varying results with respect to the age of rocks. If the $\mathrm{K}$-Ar results, including ${ }^{40} \mathrm{Ar} /{ }^{39} \mathrm{Ar}$, are considered simply as cooling ages, the results suggest that an Early Cretaceous thermal event affected the much older metamorphic complex and was of sufficient intensity to reset amphibole (about $500^{\circ} \mathrm{C}$ ). Many of the $\mathrm{K}$-Ar ages determined, both on metamorphic and plutonic rocks, were Mesozoic and commonly discordant when multiple minerals from the same sample could be dated. These highly discordant ages may suggest a long slow cooling. A few samples show the same reverse discordance as the plutonic rocks mentioned earlier in which hornblende yields younger ages than co-existing biotite or muscovite, or in which muscovite yields younger ages than coexisting biotite. However, for most samples, hornblende ages are 100 m.y. or more older than coexisting biotite.

A number of the K-Ar and ${ }^{40} \mathrm{Ar} /{ }^{39} \mathrm{Ar}$ ages for the Kanektok metamorphic complex fall between 120 and $150 \mathrm{Ma}$; however, many more samples yield discordant ages significantly older than $150 \mathrm{Ma}$. One sample, DT72-82, yields concordant biotite and hornblende ages of about $212 \mathrm{Ma}$ (table 1), suggesting a discrete event. Few other samples yielded concordant old ages; however, one was as old as about 480 Ma (Sample DT75-70, table 1). The minimum mica and amphibole ages are concordant at about $128 \mathrm{Ma}$.

Three pyroxene granulite samples yielded significantly older K-Ar ages than any other rocks in Alaska. Multiple analyses of biotite splits from these granulite samples yielded average ages between 2,255 \pm 71.2 and 2,474 $\pm 75 \mathrm{Ma}$ (table 1). $\mathrm{A}{ }^{40} \mathrm{Ar} /{ }^{39} \mathrm{Ar}$ age of the oldest of these samples yielded a plateau age of 2,520 $\mathrm{Ma}$ and showed no indication of excess argon. $\mathrm{U} / \mathrm{Pb}$ ages of zircon from granite gneiss and tonalite gneisses from throughout 
the complex, including locations not distant from these granulite samples, cluster around 2,050 Ma (Turner and others, 2009; Box and others, 1990; Moll-Stalcup and others, 1996; table 1, herein). Turner and others (2009) made a case that the 2.5 Ga biotite samples contain excess argon by analogy with similar rocks from elsewhere and by the suggestion that the incremental heating plateau was an experimental artifact. Multiple studies, as reported in Faure and Mensing (2005), indicate that the ${ }^{40} \mathrm{Ar} /{ }^{39} \mathrm{Ar}$ method may not be able to distinguish excess argon; therefore, the $\mathrm{U} / \mathrm{Pb}$ age of $2.05 \mathrm{Ga}$ most likely represents the best estimate of the original emplacement age of the complex.

One sphene $\mathrm{U} / \mathrm{Pb}$ age of $1,770 \mathrm{Ma}$ was measured by Turner and others (2009) and Moll-Stalcup and others (1996) and was interpreted by Turner and others (2009) to represent the age of amphibolite-facies metamorphism of the terrane. This interpretation is supported by analysis of a suite of 13 samples collected for $\mathrm{Rb} / \mathrm{Sr}$ analysis and by a single $\mathrm{K}$-Ar hornblende age. Six of the $\mathrm{Rb} / \mathrm{Sr}$ samples of Turner and others (2009) lie along a 1,780 Ma isochron. Moll-Stalcup and others (1996) similarly collected samples for $\mathrm{Rb} / \mathrm{Sr}$ analysis, which they divided into two suites: granitic-gneiss and tonalite-gneiss. The graniticgneiss suite samples scatter about a reference line at 1,800 Ma, whereas the tonalite-gneiss suite samples scatter about a 2,070 Ma reference isochron. Moll-Stalcup and others (1996) suggested either the results may indicate that the granitic gneisses are younger than the tonalite-gneiss suite or that the graniticgneiss suite $\mathrm{Rb} / \mathrm{Sr}$ systematics have been disturbed. However, in common with Turner and others (2009), Moll-Stalcup and others (1996) did not consider the fit of the data adequate to yield reliable isochron ages. Both groups of workers collected amphibolite samples and in neither case did the data from these rocks define a statistically valid line on an $\mathrm{Rb} / \mathrm{Sr}$ isotope plot. Moll-Stalcup and others (1996) indicated that the amphibolites are chemically distinct from the gneisses and form at least three groups based on their chemical affinity. They infer that the amphibolites may represent "dikes or sills that were intruded at different times." Amphibolite samples for the complex yielded widely varying conventional $\mathrm{K}-\mathrm{Ar}$ and ${ }^{40} \mathrm{Ar} /{ }^{39} \mathrm{Ar}$ ages, ranging from 130.6 to $1,778 \mathrm{Ma}$, suggesting significant thermal effects. Where multiple phases were dated, the discordance is great; for example, see sample DT76-70 in table 1.

Most samples from the tonalite-gneiss and granitic-gneiss suites yield Nd-Sm depleted-mantle model ages that range near $2.1 \mathrm{Ga}$, concordant with the $\mathrm{U} / \mathrm{Pb}$ zircon ages determined on these rocks, which suggests separation from a mantle reservoir at that time and that the $\mathrm{Sm} / \mathrm{Nd}$ ratio has been unmodified since that time (Moll-Stalcup and others, 1996). One granitic-gneiss sample yielded a $\mathrm{Sm} / \mathrm{Nd}$ model age of about $2.7 \mathrm{Ga}$ (Box and others, 1990; Moll-Stalcup and others, 1996), which suggests incorporation of an Archean component. Miller and others (1991) reported a similar result of a $2.05 \mathrm{Ga} \mathrm{U} / \mathrm{Pb}$ age and 2.5 $\mathrm{Ga} \mathrm{Sm} / \mathrm{Nd}$ model age from the Idono complex in the Iditarod quadrangle, northeast of the map area. This result also suggests incorporation of Archean crust. The Idono complex and the Kanektok metamorphic complex are the only rocks in Alaska known to have a similar early history.

\section{Kanektok Metamorphic Complex- Enigma in Southwest Alaska}

The Kanektok metamorphic complex was originally assigned a Precambrian age because the complex was more metamorphosed than nearby Paleozoic rocks (Hoare and Coonrad, 1959a, 1961b). Subsequently, a number of studies (Hoare and Coonrad, 1979; Box, 1982; Box and others, 1990; MollStalcup and others, 1996) of the Kanektok metamorphic complex and the Idono complex of Miller and others (1991) have shown that the complexes are thin slivers of Paleoproterozoic crust distinct from any in Alaska. To date, no cratonic source has been identified for these high-grade metamorphic rocks. The subsequent history of these rocks is also unclear, as geochronologic studies (Turner and others, 2009; Moll-Stalcup and others, 1996) have yet been unsuccessful at deciphering their Paleozoic and Mesozoic history.

Beyond agreement that the Kanektok metamorphic complex is a thin sliver of early Proterozoic crust, Hoare and Coonrad $(1978,1979)$ and Box, Moll-Stalcup, and coworkers (Box, 1982; Box and others, 1990; Moll-Stalcup and others, 1996) had diametrically opposed interpretations of the character of the contact with surrounding rocks and, therefore, the tectonic setting of the sliver of crust. The southeast bounding fault of the metamorphic complex was mapped and described by Hoare and Coonrad $(1978,1979)$ as a northwest-dipping low-angle thrust fault. Hoare and Coonrad (1979) reported that Cretaceous shale of the Kuskokwim Group (unit Kk) crops out in a number of places where the Kanektok River cuts through the complex. Because Kuskokwim Group rocks also crop out east of the complex, Hoare and Coonrad $(1978,1979)$ inferred that the contact was a thrust, placing the Kanektok metamorphic complex over the Cretaceous shale of the Kuskokwim Group. Conversely, Box and others (1990) and Moll-Stalcup and others (1996) interpreted the rocks of the metamorphic complex as being underthrust southeastward below Lower Cretaceous and older rocks. Box (1982; see also Box and others, 1990) inferred the metamorphic complex (Kilbuck terrane) collided with and partially underthrust the adjacent rocks that they assigned to the Goodnews and Togiak terranes, an oceanic-arc-subduction complex. However, we have difficulty reconciling Box's interpretation with the mapping of Hoare and Coonrad (1978). Additionally, Box's interpretation is difficult to reconcile with the available geochronologic data. For the most part, no contacts of the metamorphic complex with rocks on the west side of the contact are exposed; the Golden Gate Fault System is inferred to form the western boundary of the complex. The only portion of the complex in contact with a bedrock unit to the west is a very small exposure in the Bethel quadrangle. Hoare and Coonrad (1959a) showed this contact as a depositional contact with the Kuskokwim Group, whereas Box and others (1993) showed it as a fault contact, thrusting the metamorphic rocks over the Kuskokwim Group along a strand of the Golden Gate Fault. As this faulting must postdate the apparent thermal event that affected the west side of the terrane, the nature and cause of this thermal event remains to be determined. The nature of the contact and what rocks lie on the west side of the complex 


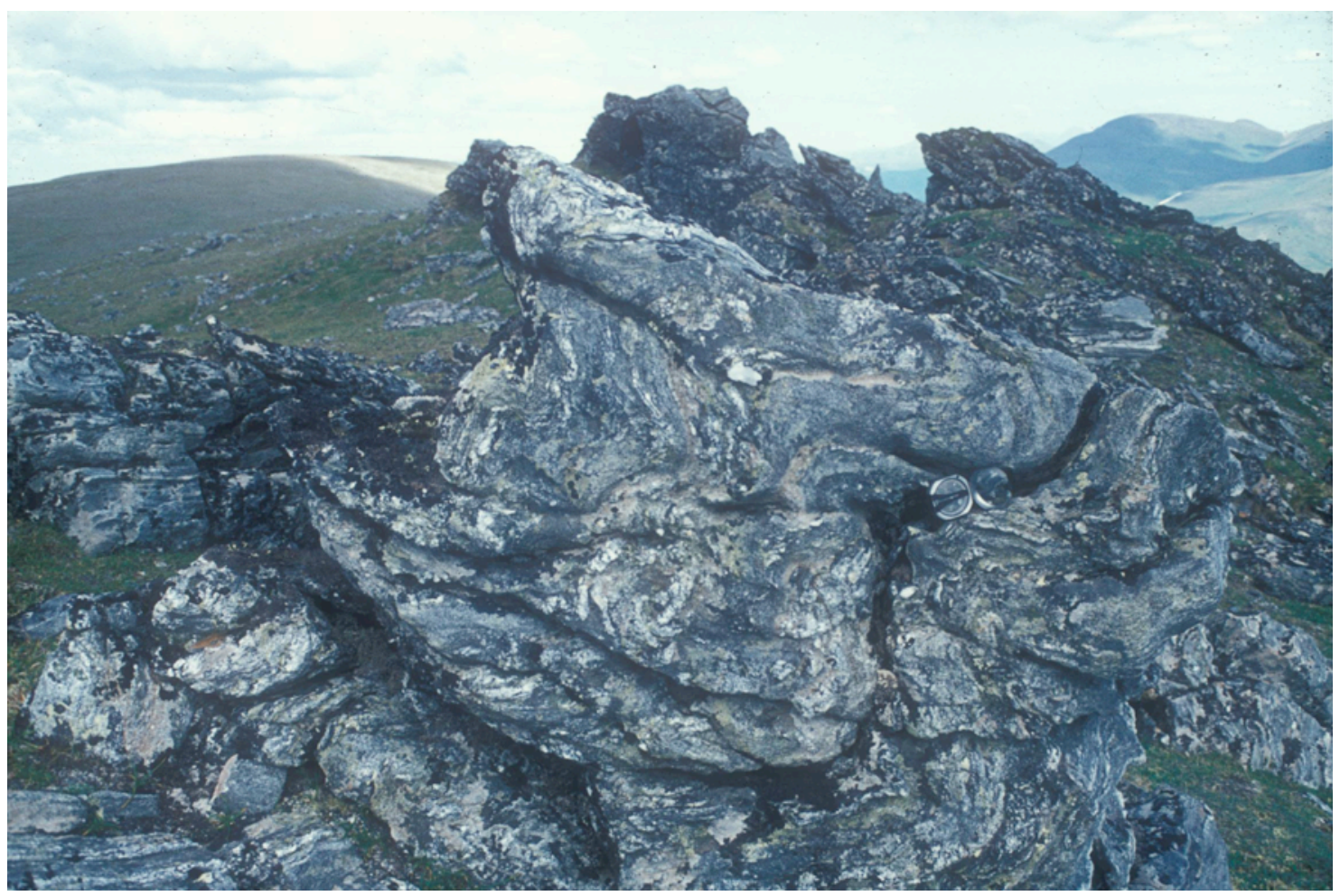

Figure 3. Gneiss of the Kanektok metamorphic complex (Ek) north of Thumb Mountain.

is unknown, especially in the vicinity of the Kanektok River and southward. R.W. Saltus (written commun., 2006) analyzed available aeromagnetic and gravity data, including a gravity traverse along the Kanektok River that crosses the metamorphic complex. In his interpretation, the metamorphic complex is a northwestward-dipping crustal block. This interpretation generally supports the mapping of Hoare and Coonrad (1978, 1979) and does not support the interpretation that the rocks of the metamorphic complex underthrust rocks to the east.

Spatial analysis of the K-Ar ages within the Kanektok metamorphic complex indicates a general pattern of decreasing age with distance from the southeast-bounding fault of the complex. Such a pattern has a number of possible interpretations. One possibility is that the easternmost parts of the complex were less affected, if at all, by the inferred Cretaceous (120-130 Ma) thermal event and may have been unroofed long before, as suggested by biotite ages of $190 \mathrm{Ma}$ and older. Inclusion of metamorphic minerals and metamorphic rock clasts in the Valanginian age sedimentary rocks of the Eek Mountains belt (unit Kcgc), deposited at approximately the same time of the inferred thermal event in the western part of the complex, as well as in the younger basal conglomerate (unit Kkn) of the Kuskokwim Group of Albian age, indicates markedly different histories for the east and west sides of the exposed complex. A different interpretation by Turner and others (2009) suggested a cluster of K-Ar ages around 120-150 Ma, with biotite and hornblende ages extending back in time to more than $1.7 \mathrm{Ga}$, which suggests variable argon loss from an Early Cretaceous to Late Jurassic thermal event. They suggested this might have been related to widespread small intrusions of an alaskite granite that is undated and not shown on available maps. However, given the spatial distribution of the ages, we consider this unlikely. An analysis of K-Ar data for the metamorphic rocks of the Yukon Crystalline Terrane of central Alaska (Wilson and others, 1985) indicated little evidence for widespread resetting of metamorphic rock due to intrusion of plutons. 


\section{DESCRIPTION OF MAP UNITS}

[Some unit exposures on the map are too small to distinguish the color for unit identification. These units are labeled where possible, and all units are identified by attributes in the digital database. Some unit labels listed in unit descriptions below refer to units not exposed within this map area]

\section{UNCONSOLIDATED DEPOSITS}

Qs Surficial deposits, undivided (Quaternary) - Unconsolidated, poorly sorted to well-sorted, poorly stratified to moderately well stratified deposits; consist predominantly of alluvial, colluvial, glacial, marine, lacustrine, eolian, and swamp deposits (Hoare and Coonrad, 1959a, 1961a,b; Box and others, 1993; Coonrad, 1957). Locally includes reworked volcanic debris including block and ash flows. Locally subdivided into the following:

Qtf Tidal flat and active estuarine deposits (Holocene) — Fine-grained silt and mud in tidal flats and active estuaries as shown on topographic maps. Also includes older, topographically higher deposits on land. The abrupt ending of the tidal flat deposits at approximately long $163^{\circ} 20^{\prime} \mathrm{W}$. in the Kuskokwim Bay quadrangle is an artifact of the topographic maps; the tidal flats likely continue along the coast to the west

Qa Alluvial deposits - Flood-plain alluvium of sand, gravel, and boulders. Locally may include sand and small pebbles from beach deposits, clay-rich silt from estuarine deposits, finegrained eolian sand, and small areas of undivided surficial deposits (Hoare and Coonrad, 1959a, 1961a; Box and others, 1993)

Qrs Reworked silt - Chiefly reworked silt, sandy silt, and bog deposits underlying a plain transitional with or slightly above areas of floodplain alluvium of Holocene age and separated from higher plains and residual islands of older silt deposits by an erosional scarp 3 to $15 \mathrm{~m}$ high (Hoare and Coonrad, 1959a)

Qb Beach deposits - Primarily fine sand to coarse gravel along modern and raised ancient beaches. Locally includes windblown dune sand. In the Kuskokwim Bay, Baird Inlet, and eastern Nunivak Island quadrangles, beach deposits extend $3 \mathrm{~km}$ inland as a series of raised beach ridges and may underlie the marine terraces farther inland. Along the Nushagak Peninsula, windblown sand derived from the adjacent tidal flats forms ridges interspersed with reworked glacially derived gravels

Qes Estuarine deposits - Generally fine silt to sand, but may include significant proportion of mud. Primarily found in the vicinity of Nushagak Bay; deposits extend well inland along the Nushagak and Igushik Rivers

Qmt Marine terraces-Raised terraces composed of many types of surficial deposits, which are primarily estuarine, tidal flat, and alluvial deposits, but may include glacial debris and outwash. Surfaces may be separated from younger active deposits by a bluff or may be gradational. Elevation ranges from less than $8 \mathrm{~m}$ in the western map area to as much as $12 \mathrm{~m}$ in the eastern map area

Qed Eolian deposits - In the Pribilof Islands, mostly composed of sand derived from alluvial sediments. Elsewhere, deposits primarily derived from glacial deposits or nearby tidal flats. In most places, the sand is loose and moves with the wind. Along the north shore of Saint Paul Island, impressive dunes occur (Barth, 1956). Deposits also widely distributed on the Nushagak Peninsula, where they overlie glacial, estuarine, and beach deposits. Lea (1989) described widespread eolian sand sheets in the Nushagak Lowland northeast of the map area and sand sheets have also been described locally (but not shown here) on the Nushagak Peninsula (W.L. Coonrad, unpub. data, 2007)

Qsd Silt deposits - Chiefly light- to dark-gray silt and sandy silt containing abundant permafrost. Deposits become sandier with depth and locally contain pebbles and wood fragments.

Deposits are probably of nonmarine fluvial origin but may include eolian and marine members in some areas. Organic muck containing mammoth remains and nonmarine gastropods is found locally near top of deposits (Hoare and Coonrad, 1959a, 1961b) 
Qg Glacial deposits, undivided - Glacial drift deposited during the last three glacial advances. Consists of sand, gravel, and boulders. Includes end and lateral moraine deposits, as well as colluvium, talus, landslide debris, alluvium, and local silt (Hoare and Coonrad, 1959a, 1961a,b; Box and others, 1993). Locally subdivided into the following:

Qgm Glacial moraine-Morainal ridges of generally late Wisconsin age, but may include deposits of other ages. Largely mapped from air-photo and topographic map interpretation. In the Nushagak Bay quadrangle, mapping is largely derived from the unpublished field data of W.L. Coonrad. Likely composed of poorly sorted silt to cobble and boulder-sized material

Qgo Outwash deposits - Poorly sorted to well-sorted sand and gravel with some silt and a few boulders, constituting terraces and outwash-fan plains (Hoare and Coonrad, 1959a, 1961a,b)

Qvs

Volcaniclastic sediment (Quaternary)_Fossiliferous sediments consisting of sand and yellow tuff containing rounded basalt pebbles. On Saint Paul Island, sediments are polymictic, but composed primarily of basaltic boulders and clasts and locally crossbedded. On Saint George Island, sediments overlie a glaciated surface of peridotite upon which Pleistocene fossil shells have been cemented. The sediments are quite varied; however, a basal conglomerate has peridotite boulders but primarily consists of basalt boulders. A sand layer containing casts of fossil shells overlies the basal conglomerate; however, no $\mathrm{CaCO}_{3}$ is left in the casts and the casts disintegrate on contact (Barth, 1956). Locally crossbedded

QTs Semiconsolidated marine beach deposits (Pleistocene or Pliocene) - Semiconsolidated marine beach deposits consisting of poorly bedded, soft, pebbly siltstone that caps sea cliffs of volcanic rock (unit Kv) on Hagemeister Island. Contains Pliocene or Pleistocene age shallowwater marine fossils

\section{SEDIMENTARY ROCKS}

Ks Summit Island Formation (Upper Cretaceous, Maastrichtian?) — Consists of lenses and intertonguing beds of nonmarine conglomerate, sandstone, carbonaceous siltstone, mudstone, and shale containing abundant plant detritus and a few coal seams (Hoare and others, 1983). In the type section, the unit "consists of about $200 \mathrm{~m}$ of massive and thick-bedded pebble [to] cobble conglomerate overlain by about $650 \mathrm{~m}$ of interbedded sandstone, siltstone, and mudstone and a few conglomerate beds" (Hoare and others, 1983). At the reference section of the unit, its character changes to consist of "about 75 percent carbonaceous mudstone, siltstone, and shale and 25 percent interbedded sandstone and pebble grit" (Hoare and others, 1983). Bedding is discontinuous and best developed in lower part of formation where thick conglomerate beds grade into pebble sandstone and sandstone beds (Hoare and others, 1983). Conglomerate clasts are well rounded, generally not larger than $10 \mathrm{~cm}$, and primarily derived from flows, tuffs, and sedimentary rocks of Jurassic and Early Cretaceous age (Hoare and others, 1983). Hoare and others (1983) also reported white quartz clasts and sparse schist and plutonic clasts; they suggest the schist clasts are derived from tectonically metamorphosed rocks that occur locally along major faults in region. Sandstone and siltstone consist of 60 to 70 percent lithic fragments and 10 to 15 percent each of quartz and feldspar (Hoare and others, 1983). Lithic component of the sandstone and siltstone is very fine-grained cherty tuff and other volcanic rock fragments, as well as argillite, quartzite, and chert (Hoare and others, 1983). Hoare and others (1983) indicated the hardness of the rocks varies with their structure and, by implication, location. At the west end of Summit Island and the west side of the unnamed adjacent headland on the mainland, the rocks dip $45^{\circ}$ to $80^{\circ}$ and are hard and well indurated. On the east end of the island and elsewhere on the mainland, dips are shallow and the rocks are less well indurated. Box (1985a) divided the unit into two subbasins along the trace of the Togiak-Tikchik Fault, based on contrasting sandstone compositions. Sandstone of his Summit subbasin (southeast of Togiak-Tikchik Fault) is composed mostly of slaty sedimentary lithic fragments, similar to underlying Jurassic sedimentary rocks. Rocks in the Summit subbasin are more than $1 \mathrm{~km}$ thick and consist of a lower conglomeratic member $(200 \mathrm{~m})$ of probable alluvial fan to braided stream origin and an upper carbonaceous shale member of probable meandering stream-flood plain origin, having channelized sandstone bodies that become finer grained and thinner upward. Paleocurrent indicators in the upper member generally indicate transport to the northeast. Sandstone of Box's Hagemeister subbasin (northwest of Togiak-Tikchik Fault) is composed of nonfoliated volcanic detritus similar to underlying Jurassic rocks. The Hagemeister subbasin 
section is also more than $1 \mathrm{~km}$ thick, consisting of a lower channelized sandstone member $(600 \mathrm{~m})$ of probable meandering stream origin, and an upper sandy member $(400 \mathrm{~m})$ having coarsening and thickening upward cycles beginning with laminated siltstone-coal intervals, which are possibly lacustrine delta deposits. Paleocurrent indicators in the Hagemeister subbasin generally indicate transport to the northwest (Box, 1985a). Plant fossils from the base of the reference section indicate a latest Cretaceous or early Tertiary age (Jack Wolfe, USGS, oral commun. 1974, cited in Hoare and others, 1983). A dike that cuts the formation yielded an age of $64.6 \pm 2 \mathrm{Ma}(74 \mathrm{ACd} 14 \mathrm{~d}$, table 1), which suggested to Hoare and others (1983) that a Late Cretaceous age for the Summit Island Formation was more probable. Subsequent dating of a dike (Box, 1985a) cutting the formation yielded an older age of 76.6 $\pm 4.5 \mathrm{Ma}$ (B78-1125G, table 1), further supporting the Late Cretaceous age assignment. Pollen, identified by R.H. Tschudy (USGS, written commun., 1975, cited in Hoare and others, 1983), formed a unique assemblage. Several of the taxa had been reported from Arctic Canada and western Siberia, but the complete assemblage was unique and therefore Tschudy was reluctant to assign the unit a definite Late Cretaceous age. However, on the basis of the fossil evidence and radiometric data, Hoare and others (1983) assigned a Late Cretaceous, possibly Maastrichtian age grained, gray, commonly micaceous and locally silty; in places is crossbedded, or contains siltstone partings. Contains rare argillite pebbles. Originally described by Cady and others (1955), the Kuskokwim Group is widespread in southwestern Alaska and, although largely a flysch deposit, unit represents a range of local depositional environments. In the Bethel quadrangle, Box and others (1993) subdivided the upper part of unit on the basis of provenance and depositional environment; however, data is insufficient to carry those distinctions throughout map area. They described three provenances (chert-clast, mixed, and volcanic) and three depositional environments (outer-fan turbidite, inner-fan turbidite, and deltaic). We have placed the deltaic environment, which is restricted to the chert-clast provenance, in the nearshore facies subdivision (Kkn) of this map. The other chert-clast provenance rocks are described as outer-fan facies and consist of thin-bedded, fine-grained, quartzose sandstone and shale with lesser thin- and thick-bedded medium-grained sandstone (Box and others, 1993). The mixed provenance rocks represent two depositional environments: an outer-fan turbidite facies consisting of a shale-rich sequence with lesser thin- to thickbedded, medium-grained sandstone sections and an inner-fan channel facies consisting of mixed shale-rich and sandstone-rich sections, with coarse sandstone and pebbly sandstone in thick-bedded, amalgamated sequences with minor interbedded shale (Box and others, 1993). Volcanic provenance rocks consist of interbedded shale, siltstone, sandstone, and conglomerate composed of rounded clasts of volcanic, volcaniclastic, and plutonic rocks deposited in slope and inner-fan environments (Box and others, 1993). Box and others (1993) divided the lower part of the Kuskokwim Group into two units: an upper shale and siltstone unit consisting of dark-gray to black, finely laminated shale, siltstone, and a thin-bedded, very finegrained sandstone and a basal conglomerate unit of pebble to boulder conglomerate, coarse sandstone, and minor interbedded medium-grained sandstone, siltstone, and shale. Box and others (1993) suggested the shale and siltstone represent sand-poor slope, interchannel, and distal basin-plain environments. Basal conglomerate is assigned to map unit Kkn herein, described below. The age of the Kuskokwim Group is not well constrained; multiple provenances and potentially multiple depositional systems are included within the map unit. Cady and others (1955) assigned an early Late Cretaceous age in part, but acknowledged collections outside their map area that might indicate an age older than Late Cretaceous and as young as Tertiary. Elder and Box (1992) and Box and others (1993) assigned an early Turonian to late Cenomanian age based on inoceramid fossils in the Bethel quadrangle, whereas Hoare and Coonrad (1959a) reported Albian and Cenomanian to Coniacian fossils from the same area, and Murphy (1989) reported Albian fossils. Other age assignments are as young as Santonian (Decker and others, 1994) or Campanian(?) (Miller and Bundtzen, 1994). Locally subdivided into the following:

Kkn Nearshore facies (Cretaceous, Turonian to Albian) - Thick-bedded quartzose sandstone, pebbly sandstone, and subordinate siltstone and shale of the deltaic facies chert-clast provenance of Box and others (1993). Also includes pebble to boulder conglomerate, coarse 
sandstone, and minor interbedded medium-grained sandstone, siltstone, and shale of the basal conglomerate of Box and others (1993). This informal subdivision of the Kuskokwim Group was originally defined by Platt and Muller (USGS unpub. data, 1957, cited in Wilson and others, 2006b) in the northeastern Taylor Mountains quadrangle; subsequent mapping in the Iditarod quadrangle to the north (Miller and Bundtzen, 1994) also described a nearshore facies. As described by Hoare and Coonrad (1959a), unit chiefly consists of conglomerate facies of interbedded graywacke and siltstone, with lesser amounts of pebble grit conglomerate and a small amount of coal. Unit is well-indurated, commonly light to dark gray, and weathers brown. Varies from volcanic wacke to quartz-chert-feldspar-rich sandstone. Fossils collected from basal conglomerate of Box and others (1993) are considered Late Cretaceous (Cenomanian) age and fossils from the deltaic facies of Box and others (1993) are considered Late Cretaceous (Turonian). Murphy (1989) reported an Albian ammonite, Paragastroplites, from this unit in the Bethel quadrangle

Kys Sandstone, shale, and conglomerate deltaic deposits (Upper Cretaceous?) —Fluvial and shallow marine deltaic deposits of sandstone, siltstone, shale, and conglomerate. Locally crossbedded and ripple marked. Unit contains abundant plant debris and fresh- and brackishwater mollusks. Unit is widely exposed in a broad belt that extends from northwest of the map area into the northern edge of the Marshall quadrangle (see Patton and others, in press, 2009; Wilson and others, 2005, 2006a,c). Shallow water marine mollusks of middle Cretaceous age found in the Kwiguk quadrangle

Kygv Volcanic graywacke and argillite (Cretaceous?) — Thinly interbedded fine-grained graywacke and siliceous argillite (Patton and others, 1975) on Saint Matthew Island. Graywacke composed of angular to subrounded feldspar, volcanic lithic, and quartz grains in an altered argillaceous matrix (Patton and others, 1975). Argillite is siliceous and dense, breaks with conchoidal fracture, shows small-scale crossbedding and convolute laminations, and is interpreted to be a distal facies of a marine turbidite. No fossils are known in this unit; however, it is thermally altered by granodiorite (unit TKgd) which yielded an age of $62.2 \pm 2.0 \mathrm{Ma}$ (71 AMm 45, table 1). Unit appears to stratigraphically underlie pyroclastic rocks, which yield $\mathrm{K}-\mathrm{Ar}$ ages of $76.0 \pm 2.0$ and $76.3 \pm 2.0 \mathrm{Ma}$ on biotite and hornblende, respectively (71AMm 50, table 1), which, in part, led Patton and others (1975) to assign a Cretaceous(?) age for the unit. Unit may correlate with unit Kygv of Patton and others (in press, 2009; Wilson and others, 2005, 2006a,c)

Kgbr Graywacke of Buchia Ridge (Lower Cretaceous, Valanginian and Hauterivian)-Lithic sandstone, conglomerate, and shale about $5 \mathrm{~km}$ thick (Hoare and Coonrad, 1983). Lower part of unit is about 2,400 m thick, composed mainly of well-bedded fine- to mediumgrained sandstone with siltstone interbeds, and pebble-cobble conglomerate. In lowest part of section, beds range from 0.1 to 3 to $4 \mathrm{~m}$ thick; the upper part of this lower section consists of 1,400 m of increasingly massive conglomerate (Hoare and Coonrad, 1983). Well-rounded clasts, as large as $10 \mathrm{~cm}$, consist of "graywacke and siltstone, cherty tuff, and less abundant porphyritic volcanic rocks" (Hoare and Coonrad, 1983); the graywacke clasts resemble the graywacke of Kulukak Bay (unit Jkw: Jln, Jmm). The conglomerate, near the top of Buchia Ridge, contains coquinas of Buchia crassicollis shells (Hoare and Coonrad, 1983). Box (1985a) interpreted this part of the unit to be of shallow marine origin. Upper part of unit, about 2,500 m thick, is "mostly shale and thin-bedded sandstone" (Hoare and Coonrad, 1983), which is poorly exposed. It is "dominantly fine-grained $* * *$ calcareous black shale, thin-bedded calcareous siltstone, sandstone, calcarenite, and minor gritstone" (Hoare and Coonrad, 1983). Box (1985a) interpreted this upper part of the section to be of probable offshore marine origin. According to Hoare and Coonrad (1983), the graywacke of Buchia Ridge "is the thickest, least deformed section of Lower Cretaceous sedimentary rocks known in southwestern Alaska." Outcrop area covers approximately $350 \mathrm{~km}^{2}$ in a thrust plate separated from its neighbors by reverse faults (Hoare and Coonrad, 1983). Lower part of section contains abundant Valanginian fauna, primarily Buchia; upper part of section yields sparse Inoceramus, Belemnites, and a single Hauterivian ammonite according to Hoare and Coonrad (1983)

KIg Limy grit and limestone of the Ungalikthluk belt of Hoare and Coonrad (1983) (Lower Cretaceous, Valanginian) - Chiefly "limestone, greenish limy grit, and conglomerate overlain by noncalcareous graywacke and grit" (Hoare and Coonrad, 1983) exposed in a small area a few kilometers northwest of Buchia Ridge. Limy grit and conglomerate consists 
of "sub rounded green and maroon lithic fragments and a few well-rounded quartz pebbles" (Hoare and Coonrad, 1983) cemented by gray bioclastic limestone consisting of tiny shell fragments. Lithic clasts are fine-grained tuff and volcanogenic sedimentary rocks metamorphosed to phyllite and low-grade quartz-chlorite-sericite schist (Hoare and Coonrad, 1983). Lithic fragments thought to be derived from "nearby strata that were tectonically metamorphosed by movement on the Ungalikthluk fault" (Hoare and Coonrad, 1983); the matrix does not have a metamorphic fabric suggesting that metamorphism and therefore fault movement were pre-Early Cretaceous (Hoare and Coonrad, 1983). Bioclastic limestone is composed mostly of microscopic shell fragments. Buchia crassicollis is found in some limestone beds and Hoare and Coonrad (1983) suggested that the shell fragments in the bioclastic limestone were derived from Buchia. The presence of Buchia crassicollis indicates these rocks are coeval with the graywacke of Buchia Ridge (Kgbr)

Kvm Volcanic and sedimentary rocks of the Mount Oratia belt of Hoare and Coonrad (1983) (Lower Cretaceous, Valanginian) - Consists of a variety of lithologies including thin-bedded tuffaceous chert, massive graywacke, conglomerate, argillite, a few volcanic flows and impure limestone beds, and massive, coarse-grained crystal-lithic tuff (Hoare and Coonrad, 1983). Rocks range widely in color, mostly green and gray but also red, yellow, brown, or black (Hoare and Coonrad, 1983). Most distinctive rock type in the belt according to Hoare and Coonrad (1983) is the massive andesitic crystal-lithic tuff, which is at least 1,000 m thick. Fine-grained tuff and some graywacke commonly contain laumontite. Buchia crassicollis of Early Cretaceous, Valanginian age is found in calcareous graywacke, conglomerate, and impure limestone. In cherty tuff, Early Cretaceous radiolaria has been found at three localities (Hoare and Coonrad, 1983). As in unit Klg, the presence of Buchia crassicollis indicates unit Kvm is coeval with the graywacke of Buchia Ridge (Kgbr)

Kcgc Calcareous graywacke and siltstone of the Eek Mountains belt of Hoare and Coonrad (1983) (Lower Cretaceous, Valanginian) - Turbidites composed of highly calcareous sandstone interbedded with non-calcareous micaceous siltstone and shale. Hoare and Coonrad (1983) inferred the unit to be coarsening upward to conglomerate. Generally thick-bedded to massive with alternating sandstone and shale intervals 5 to $20 \mathrm{~m}$ thick, locally has thinbedded sections (Hoare and Coonrad, 1983). The base of the unit is not recognized and as such Hoare and Coonrad (1983) suggested that rocks of Jurassic age may be present in the unit. Rocks are strongly folded and commonly overturned (Hoare and Coonrad, 1983). Box and others (1993) reported the presence of lithic clasts likely derived from the Kanektok metamorphic complex, as well as other local units. Buchia crassicollis is found in several areas on the northwest side of the belt. Unit is exposed in the Bethel and Goodnews Bay quadrangles and appears to correspond with similar rocks that extend in a broad belt from the southeast corner of Saint Michael quadrangle and the northwest corner of the Holy Cross quadrangle to the south-central part of the Kwiguk quadrangle (map unit Kygc, Patton and others, in press, 2009; Wilson and others, 2005, 2006a,c). No fossils have been found in this similar unit in the Saint Michael and Holy Cross quadrangles, but in the Yukon-Koyukuk Basin to the north, similar rock assemblages have yielded marine mollusks of probable late Early or early Late Cretaceous age (Patton and others, in press; Wilson and others, 2006c), slightly younger than within this map area

KRvs Volcanic and sedimentary rocks, undivided (Lower Cretaceous to Upper Triassic?) — Thick unit consisting of low-grade metamorphic or contact metamorphosed marine volcanic and sedimentary rocks. According to Hoare and Coonrad (1978), "the volcanic rocks range in composition and type from mafic pillow basalts to more abundant andesitic and trachytic flows, tuffs, and breccias. Interbedded with the volcanic rocks are thick sections of tuffaceous siltstone, tuffaceous cherts, and massive or thin-bedded argillite. Tuffs and tuffaceous sedimentary rocks associated with the intermediate-composition volcanic rocks are commonly laumontized." Radiolarians of Late Jurassic to Early Cretaceous age and fragmentary ammonites of Jurassic age have been collected from this unit in the Goodnews Bay quadrangle (Hoare and Coonrad, 1978). The unit may include some areas of rocks of Triassic and Permian age. Box and others (1993) suggested that this unit may be subdivided into the units KJc, KJb, Ja, and Jvs in the Bethel quadrangle, whereas Box (1985a) divided the unit in the Hagemeister Island and southern Goodnews Bay quadrangles into the subdivisions JIt, Jvt, and Jkcv. On the map, no contact is shown between these subdivisions and this undivided unit due to lack of mapping. Locally subdivided into the following: 
KJc Argillite and tuffaceous chert (Lower Cretaceous and (or) Upper Jurassic)—Thin-bedded, green to brown argillite having local 1- to 4-cm-thick tuffaceous chert, siltstone, and finegrained tuff interbeds (Box and others, 1993). A Late Jurassic and (or) Early Cretaceous age is suggested from poorly preserved radiolarians (Box and others, 1993). Mapped only in the Bethel quadrangle (Box and others, 1993)

KJb Pillow basalt (Lower Cretaceous and (or) Upper Jurassic) - Highly altered pillow basalt sequence exposed along a narrow trend about $1 \mathrm{~km}$ wide and $10 \mathrm{~km}$ long south of Crooked Mountain in the Bethel quadrangle (Box and others, 1993). Interbedded with argillite and thin-bedded chert of unit KJc. Age inferred from enclosing map unit. Mapped only in the Bethel quadrangle (Box and others, 1993)

Jvs Marine volcaniclastic sandstone, conglomerate, and argillite (Jurassic) — "Turbidite-facies volcaniclastic strata, locally as coarse as fine-grained pebble conglomerate" (Box and others, 1993). Clasts are predominantly intermediate volcanic rock fragments and detrital feldspar, quartz, clinopyroxene, and hornblende. Minor plutonic rock fragments, felsic volcanic and hypabyssal sedimentary rock fragments, and low-grade metamorphic rock fragments are a persistent component (Box and others, 1993). According to Box and others (1993), age control is based on stratigraphic position above Early Jurassic and Late Triassic phyllite and chert of map unit JKp and below Early Cretaceous and (or) Late Jurassic argillite and tuffaceous chert of map unit KJc. Mapped only in the Bethel quadrangle (Box and others, 1993)

Marine arkosic sandstone and argillite (Jurassic) _ “Turbidite-facies arkosic sandstone and shale" (Box and others, 1993). Sandstone, apparently derived from weathering of plutonic rocks, consists primarily of detrital plagioclase, quartz, and potassium feldspar, and minor hornblende, biotite, and clinopyroxene, in contrast to sandstone of map unit Jvs, which had a largely volcanic source (Box and others, 1993). Age inferred based on stratigraphic position above Early Jurassic and Late Triassic phyllite and chert (unit Jkp) and on strike position relative to unit Jvs. Mapped only in the Bethel quadrangle (Box and others, 1993)

Jvt Volcaniclastic turbidites of Togiak Bay of Box (1985a) (Middle Jurassic)_Volcaniclastic turbidite sandstone and conglomerate composed entirely of volcanic and hypabyssal igneous clasts; unit is at least $1.7 \mathrm{~km}$ thick (Box, 1985a). Box (1985a) divided a tightly folded section along the seacoast into a buff-colored lower member, $1 \mathrm{~km}$ thick, and a bright green upper member, $0.7 \mathrm{~km}$ thick. Lower unit consists of thin-bedded fine-grained sandstone and siltstone turbidites and channelized medium- to coarse-grained sandstone and minor chaotic interbeds indicating downslope mass movement, which suggests an inner fan to midfan environment (fig. 10, Walker and Mutti, 1973). Upper, more tuffaceous member is mostly thin-bedded fine-grained sandstone and siltstone turbidites, having coarse conglomerate beds in upper part showing poorly defined thinning and fining upward cycles. "Entire sequence interpreted as deposited on proximal channelized portion (i.e., upper to midfan) of turbidite basin fill complex" (Box, 1985a). Similar conglomerate intruded by gabbro at Aeolus Mountain; gabbro yielded $174 \pm 8 \mathrm{Ma} \mathrm{K-Ar}$ age on amphibole (B78-1171G, table 1). "A few tool marks and interbedded slump folds suggest ENE-directed paleocurrents. *** Unit is folded around sub-horizontal, northeast-trending axes and steep axial planes, and lacks a penetrative cleavage" (Box, 1985a). Box (1985a) constrained the age to Middle Jurassic on the basis of Bajocian pelecypods northeast of his map area in Togiak River valley reported by Hoare and Coonrad (1978). These rocks were included in map unit KJvs of Hoare and Coonrad (1978) and are likely to be present in undivided parts of that unit as shown herein in unit K₹vs. Mapped only in the Hagemeister Island and southern Goodnews Bay quadrangles (Box, 1985a)

Jit Laminated tuff and associated rocks of Box (1985a) (Jurassic)—Banded to finely laminated crystal-lithic tuff having interbedded green, white, and black tuffaceous chert (Box, 1985a). Unit contains minor interbedded sections of massive, coarse-grained lithic tuff and (or) pillow basalt (mapped as unit Jpb by Box, 1985a). Highly deformed, commonly having folded slaty or spaced cleavage. Partially altered to prehnite-pumpellyite facies mineral assemblage. Several chert samples have yielded Radiolaria of Jurassic age, one of which is identified as upper Kimmeridgian to upper Tithonian (latest Jurassic) (see Box, 1985a). Mapped only in the Hagemeister Island and southern Goodnews Bay quadrangles (Box, 1985a)

JKcV Coarse volcaniclastic rocks (Lower Jurassic to Upper Triassic) - Dense green tuff, tuff breccia, pillow breccia, minor pillow basalt, and associated sedimentary rocks (Box, 1985a). 
Breccia clasts are mostly angular aphanitic or plagioclase-clinopyroxene porphyritic rocks, which are commonly vesicular. Interbedded aquagene tuff and crystal tuff commonly having devitrified glass shards. Rocks are altered to prehnite-pumpellyite facies mineral assemblages and locally altered to hornblende and biotite hornfels around gabbroic plutons. Unit is exposed on both sides of Togiak-Tikchik and Kulukak Faults; age northwest of Togiak-Tikchik Fault constrained by underlying Upper Triassic basalt and crosscutting plutons of early Middle Jurassic age; southeast of Togiak-Tikchik Fault, constrained only to pre-Valanginian age (Box, 1985a). Mapped only in the Hagemeister Island and southern Goodnews Bay quadrangles (Box, 1985a)

Jvc Volcaniclastic conglomerate, sandstone, and shale (Upper and Middle Jurassic) — Poorly to moderately exposed sequence of tuffaceous marine sandstone, shale, and conglomerate having minor interbedded basalt and andesite lava flows in the northwest part of the Bethel quadrangle (Box and others, 1993). Unit is as much as 1 to $2 \mathrm{~km}$ thick; coarser parts are composed primarily of rounded clasts of basalt and andesite and minor mafic to intermediate-composition plutonic rock fragments (Box and others, 1993). Felsic pyroclastic rocks are found locally in the middle part of the unit within the map area and in the lower part of the unit north of the map area (Box and others, 1993). Marine pelecypods of Bajocian age (Middle Jurassic) are found near the base of the sequence and marine pelecypods of late Kimmeridgian to early Tithonian age (Late Jurassic) were reported from the Russian Mission quadrangle north of map area (Box and others, 1993)

Jkw Graywacke of Kulukak Bay (lower Upper to Middle Jurassic) - A thick marine sedimentary unit consisting of very hard, dark-green or gray, massive graywacke and siltstone containing local conglomerate horizons. Typically consists of sandstone, although coarse pebble conglomerate is locally present. Compositionally, "varies from quartz- and plagioclase-rich wackes to quartz-poor volcanic wackes. Generally contains black argillite or tuff chips" (Hoare and Coonrad, 1978). These rocks are the thick marine sedimentary unit referred to as the "Weary graywacke" by Hoare and others (1975). Unit is widely exposed in the southern Goodnews Bay and the Nushagak Bay quadrangles as well as the adjacent southeastern Dillingham quadrangle (Hoare and Coonrad, 1978). Buchia, Inoceramus, belemnites, and rare ammonite fragments ranging from Middle to early Late Jurassic age have been found in this unit. Locally subdivided by Box (1985a) into the following:

$\mathrm{Jmm}$

Turbidites of Metervik Bay of Box (1985a) (Upper and Middle Jurassic) — Volcaniclastic turbidite-facies sedimentary rocks southeast of Right Hand Fault of Box (1985a), which is roughly equivalent to unnamed fault of Hoare and Coonrad (1978) that parallels the valley of Ualik Lake. Box (1985a) reconstructed a 6-km-thick section, which he divided into four turbidite environment units (using criteria of Walker and Mutti, 1973, cited in Box, 1985a) from bottom to top: (1) conglomeratic inner fan; (2) well-bedded, outer fan lobe; (3) sandy, typically massive, midfan channel; and (4) conglomeratic inner fan unit. According to Box (1985a), "sandstone compositions almost entirely derived from plagioclase-rich volcanic sources. Minor slaty clasts near base of lowest unit, and minor component of slate, dioritic plutonic and chert detritus in upper unit. Interbedded slump folds suggest southeast-facing paleoslope. $* * *$ Tightly folded around gently northeast-plunging axes and sub vertical axial planes." Box (1985a) suggested deformation was probably during latest Jurassic to earliest Cretaceous time, based on occurrence of clasts of similar lithology in the lower unit of the graywacke of Buchia Ridge (unit Kgbr). Unit located southeast of map unit Jln and separated from it by the Right Hand Fault of Box (1985a); unit Kgbr is located northwest of the Kulukak Fault and northwest of map unit Jln; hence units $\mathrm{Jmm}$ and $\mathrm{Kgbr}$ are not in contact

Jin Dismembered volcaniclastic turbidites (Lower Jurassic?) —Predominately argillaceous, tuffaceous sandstone-shale sequence that is pervasively deformed and structurally dismembered (Box, 1985a). Sandstone is composed of volcanic detritus and a very minor chert component. "Sedimentary structures variably preserved and indicate deposition from turbidity currents and other mass flow processes" (Box, 1985a). Partially altered to prehnitepumpellyite mineral assemblages, the unit is divisible into two structural facies types, which occur as alternating, fault-bounded blocks (Box, 1985a). One structural facies is characterized by generally well-bedded sections showing varying degrees of disruption prior to lithification; the second structural facies is distinguished by pervasive cleavage and occurrence of sandstone boudins in an argillaceous matrix (Box, 1985a). Poorly preserved radiolaria from structural facies 1 have been identified as post-Triassic Mesozoic forms (Box, 1985a). 
Clasts of slate similar to structural facies 2 occur stratigraphically below Bajocian fossil occurrences in adjacent Middle Jurassic turbidite facies sedimentary rocks (unit Jmm). Box (1985a) interprets this to indicate that deposition and deformation of these rocks were therefore Early Jurassic in age. This unit and map unit Jmm above are found southeast of the Kulukak Fault; their outcrop area corresponds to the area shown by Hoare and Coonrad (1978) for the graywacke of Kulukak Bay (unit JKw)

\section{IGNEOUS ROCKS}

QTV Volcanic rocks, undivided (Pleistocene or Pliocene)_-Widely distributed basalt flows in the western part of the map area (Coonrad, 1957). Possibly equivalent in part to flows of map unit Qvb. In the Pribilof Islands, widespread olivine hylobasanite (containing normative nepheline) flows and sills range in thickness from $20 \mathrm{~cm}$ to $7 \mathrm{~m}$ or more (Barth, 1956); on Otter Island, hylobasanite flows are at least $100 \mathrm{~m}$ thick. Dated samples in the Pribilof Islands range from less than 0.10 to $2.25 \pm .10 \mathrm{Ma}$ (table 1). These rocks can be vesicular or dense and many eruptive features, such as hornitos (chimneys surrounded by foam and splatters), blowholes, diatremes, and miniature craters are present (Barth, 1956) suggesting very recent eruption. Other flows lack these features and are overgrown with vegetation. No dates are available on rocks of this unit except in the Pribilof Islands. Locally subdivided into the following:

Qpd Pyroclastic rocks (Quaternary) - Pyroclastic rocks in the Pribilof Islands, largely basaltic tuff (Barth, 1956). A K-Ar whole-rock age of 1.63土.06 Ma (sample P21, table 1) was determined on basalt from this unit

Qcs Alkalic basalt of Karon Lake (Quaternary) - Cinder cones, flows, and tephra; normally polarized rocks of Brunhes polarity chron (Hoare and others, 1968). K-Ar ages range from $0.03 \pm .02$ to $0.74 \pm .09 \mathrm{Ma}$ (table 1$)$

QTab Older alkalic basalt of Karon Lake - Cinder cones, flows, and tephra; reversely and normally polarized rocks of Matuyama(?) chron (Hoare and others, 1968) on Nunivak Island. A sample of basalt from this unit yielded an age of $0.88 \pm .07 \mathrm{Ma}$ (sample A50, table 1)

Qvb Basalt flows, undivided (Pleistocene) - Widely distributed fine- and medium-grained, columnar jointed tholeiite and alkali-olivine basalt flows. Columnar-jointed subaerial alkali olivine basalt flows have ropy tops and include minor interflow tuff and breccia. Generally nonporphyritic, dark-gray to black and contain fine microcrysts of labradorite, augite, olivine, and accessory magnetite in a diktytaxitic texture (Hoare and Coonrad, 1980). Includes the Togiak Basalt of Hoare and Coonrad (1980) on the floor of the Togiak River valley as well as flows in the Bethel, Nunivak Island, Cape Mendenhall, Pribilof Islands, and Baird Inlet quadrangles. The Togiak Basalt is divisible into a lower unit of low-lying horizontal flows, less than $100 \mathrm{~m}$ thick, and an upper unit, about $300 \mathrm{~m}$ thick, comprising an isolated volcanic edifice, regarded by Hoare and Coonrad (1978) as a tuya (subglacial volcano). Wholerock K-Ar age on lower unit was 0.758 $\pm 0.2 \mathrm{Ma}$ (Hoare and Coonrad, 1978, 1980; Box, 1985a, sample 74AHr 77, table 1, herein). In the Bethel quadrangle, includes fresh olivine tholeiite basalt flows having diktytaxitic texture and containing olivine, subophitic clinopyroxene, plagioclase, and iron oxides as well as sparse interstitial volcanic glass yielding a whole-rock K-Ar age of $0.418 \pm 0.016 \mathrm{Ma}$ (Box and others, 1993, sample 86ASb 9a, table 1, herein). Unit also includes Tholeiitic Basalt of Mekoryuk on Nunivak Island (Hoare and others, 1968); massive, columnar-jointed flows including both normally polarized rocks of the Brunhes polarity chron and reversely magnetized rocks of the Matuyama polarity chron (shown as unit Qvbm). Samples dated by K-Ar for this unit on Nunivak Island yielded ages as old as 1.69土.09 Ma (table 1). Locally subdivided on Nunivak Island into:

Qvbm Basalt flows of Matuyama Chron-Reversely and normally magnetized flows of the Matuyama polarity chron on Nunivak Island (Hoare and others, 1968); similar rocks may occur on the mainland but cannot be distinguished because no magnetic studies have been undertaken

Ttb Tholeiitic basalt of Binakslit Bluff (Pliocene) — Tholeiitic basalt of Binakslit Bluff on Nunivak Island; massive, columnar-jointed flows; normally polarized flows of Gauss polarity chron as well as normally and reversely polarized flows older than Gauss polarity chron (Hoare and others, 1968). Multiple samples yielded ages between $3.24 \pm 0.10$ and 5.01 $\pm 0.15 \mathrm{Ma}$ (table 1)

Talb Alkalic basalt of Ahzwiryuk Bluff (Pliocene) - Alkalic basalt of Ahzwiryuk Bluff on Nunivak Island; nubbly mottled flows and pyroclastic ejecta; includes both normally and reversely 
polarized rocks older than Gauss polarity chron (Hoare and others, 1968). Two samples yielded K-Ar ages of 5.19 \pm 0.15 and $6.28 \pm 0.18 \mathrm{Ma}$ (samples A15 and A1, respectively, table 1)

Tfi Felsic intrusive rocks (Miocene?) - Light-colored, fine-grained, commonly porphyritic felsic intrusive rocks. Chiefly rhyolitic to dacitic dikes and sills. K-Ar age on biotite of $13.00 \pm 0.50$ Ma (Hoare and Coonrad, 1978, sample 74AHr 26, table 1, herein)

Tad Aplite on Saint George Island (Eocene) - Aplite dike, about $400 \mathrm{~m}$ wide, has chilled margins where it intrudes peridotite on Saint George Island (Barth, 1956). The dike and peridotite surface is overlain by till and fine-grained sedimentary deposits, which are in turn overlain by basalt and basanite flows of map unit Qvb. Radiometric dating (Hopkins and Silberman, 1978; table 1 herein) indicates an age range of about $49.5 \pm 2.0$ to $57.2 \pm 2.3 \mathrm{Ma}$

Tnr Nukluk Volcanic Field, rhyolite (Eocene)-Moderately altered rhyolite flows, domes, and ashflow tuff. Rhyolite of the main volcanic field contains phenocrysts of sanidine, riebeckitic amphibole, and rare quartz. $\mathrm{A}^{40} \mathrm{Ar} /{ }^{39} \mathrm{Ar}$ total-fusion age on riebeckite was $54.7 \pm 1.6 \mathrm{Ma}$ (Box and others, 1993, sample 87ACz 75m, table 1 herein)

Tnba Nukluk Volcanic Field, basalt and andesite (Eocene)_Massive, columnar-jointed basalt and subordinate andesite flows. Minor latite and dacite. Overlies Tnr in Fog River area. Elsewhere, interbedded with rhyolite (Box and others, 1993)

Tvep Rhyolite and dacite tuff (Tertiary) - Chiefly rhyolite and dacite welded tuff and tuff breccia and dark rhyolite vitrophyre on the northern part of Saint Matthew Island (Patton and others, 1975) containing minor intercalated andesite and basalt flows and dikes. On southwestern part of island, chiefly light-colored rhyolite and dacite hypabyssal rocks (Patton and others, 1975). These felsic rocks appear to overlie mafic flows and volcaniclastic rocks mapped herein as unit $\mathrm{Kv}$ and may be extrusive and hypabyssal cogenetic equivalent of granodiorite mapped herein as unit TKm (Patton and others, 1975). Age thought to be Eocene or Paleocene (see Wittbrodt and others, 1989)

TMzp Peridotite on Saint George Island (Tertiary or older)_Peridotite forming the basement of Saint George Island in the Pribilof Islands. The peridotite is massive, originally was dunite, and now is largely altered to serpentine and magnetite (Barth, 1956). The erosional surface of the peridotite appears polished, has glacial striae and a brownish-black varnish (Barth, 1956, p. 117). Intruded by an aplite dike of unit Tad, suggesting age is greater than $57 \mathrm{Ma}$

TKr Rhyolite and dacite flows, tuff, dikes, and sills (Early Tertiary and (or) Late Cretaceous) - Rhyolite and dacite flows and tuff including block-and-ash flows as well as rhyolite domes. Unit includes felsic rocks of the Swift Creek, Tulip, and Eek volcanic fields of Box and others (1993). Consists of fresh to moderately altered, densely welded rhyolitic ash-flow tuff, black glassy vitrophyre, and pale pink to orange, fine-grained, porphyritic albite-bearing rhyolite. The rhyolite commonly has well-developed flow structures and forms rhyolite domes found as small knobs or large domal hills as much as $4 \mathrm{~km}$ in diameter which have 300 to $500 \mathrm{~m}$ of relief (Box and others, 1993), as well as small stock-like intrusions, dikes, and sills (Hoare and Coonrad, 1959a). The block-and-ash flow in the Tulip volcanic field consists of broken blocks of dacite in an ashy dacitic matrix and was interpreted to be a hot avalanche deposit formed during dome collapse. Dacite and subordinate andesite flows in the Tulip volcanic field, which crop out as columnar-jointed cliffs, are also included here. K-Ar ages range from $59.3 \pm 1.8 \mathrm{Ma}$ on a whole-rock to $62.5 \pm 1.9$ Ma on biotite (table 1)

TKa Eek and Swift Creek volcanic fields of Box and others (1993); andesite flows (Early Tertiary and (or) Late Cretaceous) - Small outcrops of columnar jointed andesite flows. Subordinate altered andesite porphyry is exposed in the northern part of the Eek volcanic field. Map unit also includes minor olivine basalt, andesitic lithic tuff, dacite, and a small amount of obsidian and siliceous tuff (Hoare and Coonrad, 1959a). Primarily exposed on the west side of the Bethel quadrangle along ridges and in river cuts in the Eek volcanic field; however, the Swift Creek volcanic field also contains exposures of columnar jointed andesite capping small hills in the southeastern part of the Bethel quadrangle (Box and others, 1993). According to Hoare and Coonrad (1959a) this map unit is moderately folded and unconformable on steeply dipping rocks of Cretaceous age and older. $\mathrm{A}^{40} \mathrm{Ar} /{ }^{39} \mathrm{Ar}$ total fusion age of $59.5 \pm 12.3$ Ma was determined on plagioclase from andesite in the central Bethel quadrangle (Box and others, 1993, sample 88Al 12, herein) 
TKg Granitic rocks, undivided (Tertiary and (or) Cretaceous) - Fine- to coarse-grained or porphyritic, light- to dark-gray, rarely pink, granitic rocks. Range in composition from granite to quartz diorite, including granodiorite, quartz monzonite, and quartz monzodiorite. Biotite and hornblende are locally common; muscovite is uncommon. $\mathrm{K}-\mathrm{Ar}$ and ${ }^{40} \mathrm{Ar} /{ }^{39} \mathrm{Ar}$ ages range from 60.7 to $75 \mathrm{Ma}$ throughout the map area for rocks of this unit and its subdivisions

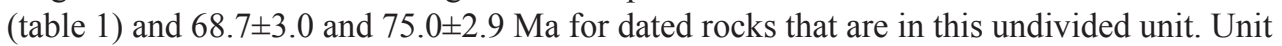
includes the Fisher Dome and Marvel Creek plutons of Box and others (1993). Also includes map unit TKg of Hoare and Coonrad (1978) except where subdivision of these rocks is possible on the basis of composition. Rocks assigned to this map unit by Hoare and Coonrad (1978) on Hagemeister Island were subsequently assigned to map unit Jmf of Middle Jurassic age by Box (1985a). Locally subdivided into the following:

TKgr Granite - Coarse- to medium-grained granite and granitoid porphyry. Biotite is dominant mafic phase, hornblende is sparsely present; feldspars are microcline and albite-oligoclase (Wilson, 1977). Unit includes the Akuluktok and Gechiak plutons of Wilson (1977) as well as Aniak Lake pluton of Box and others (1993) and the Nayorurun River intrusive complex of Hoare and Coonrad (1978) consisting of granite porphyry dikes, sills, and related tuff and breccia. The Aniak Lake pluton is a coarse-grained, porphyritic to seriate leucocratic biotite granite pluton $10 \mathrm{~km}^{2}$ in area in the Bethel quadrangle (Box and others, 1993). It has a distinctive speckled appearance due to randomly oriented microperthite feldspar phenocrysts. Porphyritic rhyolite dikes common in the uppermost part of this pluton and in surrounding biotite hornfels. $\mathrm{K}-\mathrm{Ar}$ and ${ }^{40} \mathrm{Ar} /{ }^{39} \mathrm{Ar}$ total-fusion ages for this unit range from $60.7 \pm 1.8$ Ma to $69.6 \pm 2.1 \mathrm{Ma}$ (table 1). The Akuluktok pluton yielded reversely discordant ages with biotite at 69.6 2.1 Ma and hornblende at $63.4 \pm 3.0 \mathrm{Ma}$ (Wilson, 1977; sample 74B57, table1 herein). To the east of the map area, rocks of this map unit range from $54.5 \pm 1.6 \mathrm{Ma}$ on hornblende, considered a minimum age and not an emplacement age by Wallace and others (1989) to $66.64 \pm 0.08 \mathrm{Ma}$ on mica (Wilson and others, 2003)

TKgs Monzonite-Medium-grained pyroxene-bearing monzonite. Biotite is the dominant mafic mineral; however, these plutons are characterized by the presence of orthopyroxene. Includes the Ualik Lake and Kulukak plutons of Wilson (1977). The chemically and texturally similar Okstukuk Hills and Kulik Lake plutons occur in the adjacent Dillingham quadrangle (Wilson, 1977; Wilson and others, 2006b). Potassium content is high relative to $\mathrm{SiO}_{2}$, as high as 4.50 percent $\mathrm{K}_{2} \mathrm{O}$ at a $\mathrm{SiO}_{2}$ value of 57.4 percent (Wilson, 1977). A K-Ar age of $71.9 \pm 2.0 \mathrm{Ma}$ (sample $74 \mathrm{AHr} 51$, table 1) was determined on a pluton in the Nushagak Bay quadrangle, whereas the Okstukuk Hills pluton in the adjacent Dillingham quadrangle yielded an age of $84.49 \pm 0.05 \mathrm{Ma}$ (Iriondo and others, 2003; Wilson and others, 2006b) which is unusually old for this region

TKqm Quartz monzonite and quartz monzodiorite - Medium- to coarse-grained, light-gray monzogranite or quartz monzodiorite plutons which may contain biotite, hornblende, sodic amphibole, and (or) clinopyroxene and orthopyroxene (Wilson, 1977). Locally contain phenocrysts of perthitic feldspar; biotite to hornblende ratio is variable but generally subequal (Wilson, 1977). These plutons are the most common of the Tertiary and (or) Cretaceous plutons of the map area. Includes Crooked Mountain and Canyon Creek plutons of Box and others (1993) in the Bethel quadrangle. As described by Box and others (1993), Crooked Mountain is a large composite pluton having a thin gabbro and diorite margin that partially rims a massive core of augite-biotite-hornblende and (augite-) hornblendebiotite granodiorite, quartz monzonite, and granite. Canyon Creek pluton is a small $(\sim 1$ $\mathrm{km}^{2}$ ), medium- to coarse-grained, intergranular to hypidiomorphic-granular augite-biotite quartz diorite to hornblende-biotite granodiorite. K-Ar and ${ }^{40} \mathrm{Ar} /{ }^{39} \mathrm{Ar}$ ages range from 63.7 to $71.1 \mathrm{Ma}$ (table 1); the Togiak Lake pluton of Wilson (1977) yielded a discordant $\mathrm{K}$-Ar age of $63.7 \pm 2.0 \mathrm{Ma}$ on biotite and $69.5 \pm 3.0 \mathrm{Ma}$ on hornblende (74AHr 118, table 1). ${ }^{40} \mathrm{Ar} /{ }^{39} \mathrm{Ar}$ total-fusion ages of $69.8 \pm 2.1 \mathrm{Ma}$ were determined on biotite from Crooked Mountain pluton and 70.3 $\pm 2.1 \mathrm{Ma}$ on biotite from Canyon Creek pluton (87ATf 51 and 87AJm 36a, respectively, table 1)

TKgd Granodiorite - Consists of plutons in the Saint Matthew, Goodnews Bay, and Bethel quadrangles. On Saint Matthew Island, a fine-grained hornblende granodiorite yielded a $62.3 \pm 2.0$ Ma K-Ar age on hornblende (Patton and others, 1975, 71AMm 45, table 1 herein). In the Goodnews Bay quadrangle, the Sunday Creek and Mt. Waskey plutons of Wilson (1977) are medium- to coarse-grained tonalite and granodiorite. The Sunday Creek pluton yielded 
a K-Ar age on biotite of $72.5 \pm 2.2 \mathrm{Ma}$ (GC1-1381, table 1), whereas the Mt. Waskey pluton yielded slightly discordant $\mathrm{K}$-Ar ages of $62.5 \pm 1.9$ and $65.2 \pm 2.0 \mathrm{Ma}$ on biotite and hornblende (GD1-3154, table 1). In the Bethel quadrangle, includes the two-phase North Fork pluton of Box and others (1993) and the Cripple Mountain pluton. Aplite dikes are common near these plutons. Main felsic phase of the North Fork pluton is seriate to hypidiomorphic granular (augite-) hornblende-biotite quartz monzodiorite, granodiorite, and minor biotite granite. The North Fork mafic phase is a coarse-grained, cumulate-textured augite quartz gabbro and quartz diorite. Cripple Mountain pluton is an elliptical, coarse-grained, hypidiomorphic-granular hornblende-biotite granodiorite and granite, and lesser quartz monzodiorite and quartz monzonite covering about $40 \mathrm{~km}^{2}$ in the Bethel quadrangle (Box and others, 1993). The pluton is erosionally recessive wherein the contact aureole and surrounding country rock are more resistant to erosion than the pluton. North Fork and Cripple Mountain plutons yield ${ }^{40} \mathrm{Ar} /{ }^{39} \mathrm{Ar}$ total-fusion ages of $64.3 \pm 1.9$ and $62.2 \pm 1.9 \mathrm{Ma}$, respectively (87ATf 56 and 87 ATf 72 , respectively, table 1 )

TKqd Monzodiorite and quartz diorite - Consists of the Eek River, Gemuk Mountain, Mount Plummer plutons of Box and others (1993) and the hornblende diorite stocks and dikes assigned a Late Cretaceous age by Box and others (1993) as well as the Wattamuse pluton of Wilson (1977). Plutons are fine- to coarse-grained monzodiorite and diorite, but locally include gabbro. Eek River pluton is a sill 50 to $500 \mathrm{~m}$ thick cropping out in discontinuous exposures over $10 \mathrm{~km}$ length which intruded and contact-metamorphosed rocks of the Kuskokwim Group (Kk). It is dominantly medium- to coarse-grained, porphyritic to diabasic (hornblende) augite diorite, quartz diorite, and mafic quartz monzodiorite. Gemuk Mountain pluton is elongate, north-trending, erosionally resistant, mafic to intermediate quartz gabbro to mafic granodiorite pluton. The pluton also intruded and contact-metamorphosed the Kuskokwim Group as well as Lower Cretaceous marine volcaniclastic sandstone, conglomerate, shale, and interbedded tuff of map unit Kvm. Mt. Plummer pluton is medium- to coarse-grained, erosionally resistant, hypidiomorphic granular augite-biotite mafic granodiorite, quartz monzodiorite, and quartz diorite; it intruded and contact metamorphosed the Kuskokwim Group. The Mt. Plummer pluton has yielded K-Ar biotite ages of $65.1 \pm 2.0 \mathrm{Ma}$ (87ACz 61, table 1) and 66.6 $\pm 2.0 \mathrm{Ma}$ in the adjacent Russian Mission quadrangle north of the map area (Box and others, 1993). Hornblende diorite stocks and dikes are small, extensively altered, and contain relict euhedral plagioclase; samples yielded a ${ }^{40} \mathrm{Ar} /{ }^{39} \mathrm{Ar}$ totalfusion age of $68.0 \pm 2.0 \mathrm{Ma}$ on hornblende (87AJm 271b, table 1) and a conventional K-Ar age of 71.3 \pm 2.1 Ma on biotite (GB7-1479a, table 1)

TKm Mafic intrusive rocks (Paleocene and Cretaceous?) - Dark-colored dikes and sills of diabase, basalt, and dioritic, gabbroic, and biotite lamprophyre (Hoare and Coonrad, 1978). K-Ar age of $64.6 \pm 2 \mathrm{Ma}$ on biotite (74ACd 14d, table 1) from the western Nushagak Bay quadrangle. Also includes medium- to coarse-grained pyroxene gabbro dike(?) on Saint Matthew Island (Patton and others, 1975)

TJih Hypabyssal felsic intrusive rocks (earliest Tertiary? to Late Jurassic?) — Highly altered porphyritic rocks consisting of orange-weathering rhyolite and dacite. Rhyolite contains as much as 10 percent phenocrysts, locally in graphic intergrowths, in an altered groundmass of quartz, potassium feldspar, and plagioclase. Dacite contains as much as 5 percent phenocrysts of plagioclase and biotite in a groundmass of plagioclase, quartz, and opaque oxides (Box and others, 1993). Some of these rocks have similar trace element signatures to the Slate Creek pluton (unit TJis) of Box and others (1993). Age is uncertain though rocks intrude the rocks of units Jab and Jvc

TJis Slate Creek pluton of Box and others (1993) (earliest Tertiary? to Late Jurassic?) — Small, medium-grained hypidiomorphic-granular, hornblende tonalite and granodiorite pluton, less than $2 \mathrm{~km}^{2}$. Intrudes rocks of map unit Jab without development of a prominent contactmetamorphic zone. Pluton is relatively quartz-rich, containing 20 to 25 percent quartz, along with green hornblende, plagioclase, and opaque oxides (Box and others, 1993). Pluton erodes similarly to country rocks, hence is not prominent and was considered "erosionally neutral" by Box and others (1993). Age is uncertain

TJik Little Kasigluk River pluton of Box and others (1993) (earliest Tertiary? to Late Jurassic?) - Medium-grained, hypidiomorphic granular hornblende diorite and gabbro in a number of small plutons (Box and others, 1993) in the central to western Bethel quadrangle. Age is uncertain 

from rhyolite to olivine basalt flows, dacitic to andesitic tuff and tuffaceous sandstone (line pattern), and rhyolitic domes (Hoare and Coonrad, 1978; Patton and others, 1975; Box 1985a; Box and others, 1993). Includes rhyolite domes and flows of the Tulip volcanic field, lithic air-fall tuff of the Swift Creek volcanic field, and andesite and basalt flows, tuff, tuffaceous sandstone, and rhyolite domes and flows of the Kipchuk volcanic field (Box and others, 1993). Also includes moderately to steeply dipping, fresh to weakly altered porphyritic basaltic andesite flows of calc-alkaline affinity and interbedded sandy to boulder-rich volcaniclastic rocks mapped by Globerman (1985) and Box (1985a) in the Hagemeister Island quadrangle which were originally mapped as unit Tv by Hoare and Coonrad (1978). Associated dikes cut underlying units. In the Hagemeister Island and southern Goodnews Bay quadrangles, unit overlies Upper Cretaceous Summit Island Formation (Ks) on Summit Island and adjacent mainland. On Hagemeister Island, unit consists of individual 2- to 5 -m-thick subaerial flows aggregating to at least $2 \mathrm{~km}$ thick with very minor fluvial sandstone interbeds. On Crooked Island, unit has similar flows but has more voluminous (25 percent) interbedded epiclastic volcanic sandstone and coarse boulder conglomerate. On mainland coast, northwest of Right Hand Point, consists almost entirely of boulder-rich volcaniclastic sedimentary rocks of probable debris-flow origin and very minor flows. On Saint Matthew Island, consists of flat-lying to gently dipping mafic flows of andesite and basalt and volcaniclastic rocks consisting of andesitic and basaltic tuff and conglomerate. K-Ar and ${ }^{40} \mathrm{Ar} /{ }^{39} \mathrm{Ar}$ ages range from $64.5 \pm 2.0 \mathrm{Ma}$ to $79.2 \pm 2.4 \mathrm{Ma}$ (table 1); however, a basalt sill from Saint Matthew Island yielded a whole-rock K-Ar age of 52.2 $\pm 1.6 \mathrm{Ma}$ (Wittbrodt and others, 1989, sample 12-106, table 1 herein). As this sample yields a significantly younger age than other dated rocks from Saint Matthew Island, Wittbrodt and others (1989) suggested that the basalt sill was derived from a significantly younger event, which intruded unit Kv. In the Bethel quadrangle, internal contacts reflect distinction between flow and tuff units of Box and others (1993); pyroclastic and felsic subunits are shown with a dot pattern

Kpd Intermediate and silicic pyroclastic rocks (Late Cretaceous) - Intermediate and silicic pyroclastic rocks on Saint Matthew Island including dacite, andesite, and rhyolite nonwelded tuff breccia and crystal tuff, dacite and rhyolite welded tuff, massive dacite breccia (lahar?), fine ash-fall tuff, volcanic conglomerate, and andesite and dacite porphyritic and vitrophyric plugs, dikes, sills, and flows (Patton and others, 1975). K-Ar ages were 76.0 \pm 2.0 and 76.3 $\pm 2.0 \mathrm{Ma}$ on biotite and hornblende (sample 71 AMm 50, table 1). Late Cretaceous pollen assemblages from carbonaceous tuffs (R.A. Scott, oral commun., 1973; reported in Patton and others, 1975)

Ksp Serpentinite (Late Cretaceous?)—Small, pervasively slickensided bodies of serpentinite, serpentinite-matrix melange, and silica-carbonate-altered serpentinite north of mouth of Crooked Creek (Box and others, 1993). Protolith and intrusion age uncertain; Box and others (1993) infer intrusion during Late Cretaceous tectonism

Kg Granodiorite and granite (Early Cretaceous) - Consists of the Nyac pluton in Kilbuck Mountains, only a small part of which is exposed in the northernmost part of the Bethel quadrangle; the bulk of the exposure of the pluton is in the adjacent Russian Mission quadrangle (Box and others, 1993). About $200 \mathrm{~km}^{2}$ in size, pluton is crudely concentrically zoned from hornblende-biotite granodiorite and granite at margin to hornblende-biotite granite at core (Box and others, 1993). K-Ar age determinations yield a range of ages, from 101.1 \pm 3.0 Ma (Decker and others, 1984; Box and others, 1993) on hornblende in the Russian Mission quadrangle north of the map area to $120.0 \pm 3.3 \mathrm{Ma}$ on biotite (Wilson, 1977; Box and others, 1993) also in the Russian Mission quadrangle, as well as a K-Ar biotite age of $115 \pm 3.5 \mathrm{Ma}$ from within the Bethel quadrangle (sample 87ATf 30, table 1) and a U/Pb crystallization age reported as a range of 104 to $129 \mathrm{Ma}$ (upper Concordia intercept) on zircon (see table 1, also for additional data see Box and others, 1993; Patton and others, 2009; Wilson and others, 2006a)

KJba Basaltic and andesitic lava flows (Early Cretaceous and (or) Late Jurassic)_Poorly to moderately exposed basalt and andesite lava flows in the west-central part of the Bethel quadrangle (Box and others, 1993). Overlies volcaniclastic sedimentary rocks of map unit Jvc and generally spatially associated with rocks of map unit Jab

Jum Ultramafic rocks (Jurassic?) - Serpentinite, serpentinized dunite, and other ultramafic rocks form a number of intrusive bodies and tectonic blocks(?) within fault zones separating 
pillow basalt (Kob) and pyroxene gabbro (Kog), respectively (Hoare and Coonrad, 1978; Box, 1985a). At Red and Susie Mountains, south of Goodnews Bay, the rocks consist of medium-grained, partially serpentinized dunite, wehrlite, and clinopyroxenite (Box, 1985a); Hoare and Coonrad (1978) reported websterite rather than wehrlite. The margins of these bodies are cut by numerous coarsely pegmatitic hornblendite dikes which have contact metamorphic zones as much as $800 \mathrm{~m}$ wide (Box, 1985a). Unit, as mapped herein, also includes serpentinite at Cape Newenham, which apparently had a protolith that was predominately harzburgite, subordinate dunite, and rare clinopyroxenite (Box, 1985a). This serpentinite "varies from blocky, unsheared protoliths [harzburgite?] to slickensided serpentinite enclosing blocks with original fabrics" (Box, 1985a). According to Box (1985a), the northeast flank of the ultramafic body at Susie Mountain appears to grade into hornblende gabbro of map unit Jgb, which yielded an age of 162.4 $\pm 4.9 \mathrm{Ma}$ (GA7-1450, table 1), significantly younger than the dated dikes that cut the ultramafic body at Red Mountain. K-Ar dates were 176.4 \pm 5.3 and 186.9 $\pm 5.6 \mathrm{Ma}$ (HD6-2272a and HD6-1453e, respectively, table 1) on amphibole from the crosscutting hornblendite dikes

Jab Andesite and basalt (Middle Jurassic) - Massive andesitic and basaltic flows; minor trachyte, trachyandesite, and dacite; some interbedded tuffaceous sedimentary rocks; and, locally, several hundred feet of volcanic breccia at or near base (Box and others, 1993). An estimated 25 percent of the unit is interbedded graywacke, siltstone, impure limestone, and pebble conglomerate (Hoare and Coonrad, 1959a). This rock unit forms a belt of low rolling hills on the west flank of the Kuskokwim Mountains from the Kwethluk River and northward (Hoare and Coonrad, 1959a). Marine pelecypods of Bajocian (Middle Jurassic) age occur in sedimentary strata of this unit (Hoare and Coonrad, 1959a; Box and others, 1993). Assigned to Nyac terrane by Box and others (1993)

Jmv Interbedded volcanic and sedimentary rocks (Middle Jurassic) —Basaltic and andesitic volcanic and volcaniclastic rocks on Hagemeister Island (Hoare and Coonrad, 1978; Box, 1985a); extensively altered to prehnite-pumpellyite facies mineral assemblage. Volcanic rocks, characterized by plagioclase + clinopyroxene \pm hornblende porphyritic rocks, more common in lower third of exposed section. Interbedded clastic rocks are composed almost entirely of volcanic lithic detritus, except for a lower conglomerate, which contains a minor proportion of granitic plutonic rock clasts similar to adjacent pluton. Sedimentary facies range from fluvial deltaic to nearshore marine to subwave base turbidites. Box (1985a) mapped the contact between this unit and similar older volcanic and sedimentary rocks (unit Jlvs) structurally and stratigraphically below it as a low-angle thrust(?) that he suggested is probably a faulted unconformity. Fossils of Middle Jurassic age are locally common (Box, 1985a). Conglomerate includes clasts of granitic rocks similar to nearby Middle Jurassic Hagemeister pluton (Box, 1985a), mapped herein as unit Jlgd

Jgb Gabbroic rocks (Middle and Early Jurassic) - Medium- to coarse-grained, locally pegmatitic hornblende gabbro to diorite (Hoare and Coonrad, 1978). Plutons locally contain olivine and commonly are compositionally layered (Hoare and Coonrad, 1978). Box (1985a) described these rocks as slightly altered, containing sericitized plagioclase, hornblende partially replaced by actinolite and chlorite, and prehnite-quartz veinlets. Hoare and Coonrad (1978) reported that these gabbroic intrusions are commonly associated with ultramafic rocks. Five K-Ar amphibole and hornblende ages have a bimodal distribution, having peaks at about 187 and $161 \mathrm{Ma}$ (table 1)

Jlvs Volcanic and sedimentary rocks (Lower Jurassic) - Marine unit of mafic flows, some displaying pillow structure, volcanic breccia, and massive fine- to medium-grained volcanogenic sedimentary rocks (Hoare and Coonrad, 1978). Fractures commonly coated with laumontite. Mapped as unit Jlv by Box (1985a) who described the unit as grading from a lower massive, sub-wave-base, angular pebbly mudstone to upper abundantly fossiliferous, shallow marine, well-bedded, locally crossbedded sandstone and shale. Unit only exposed on Hagemeister Island. An impure sandy limestone that outcrops in the Taylor Mountains quadrangle to the east of map area was originally included in this unit by Hoare and Coonrad (1978) because of the common occurrence of Weyla pelecypods of Early Jurassic age; however, the limestone was mapped as a distinctive unit by Wilson and others (2006b)

Jlgd Hagemeister pluton of Box (1985a) (Early Jurassic?) - Medium-grained biotite-hornblende granodiorite of Hagemeister Island; slightly altered (that is, sericitized plagioclase, chlorite partially replacing biotite and hornblende) as described by Box (1985a). Intrudes Lower 
Jurassic volcanic and sedimentary rocks (map unit Jlvs) with a narrow contact metamorphic zone of hornblende-biotite-plagioclase hornfels. Box (1985a) reported that clasts of similar granodiorite occur in conglomerate of adjacent interbedded volcanic and sedimentary rocks of map unit Jmv. An age reported variously by Box (1985a) as on biotite (p. 26) or hornblende (p. 18) yielded K-Ar age of $183 \pm 7$ Ma (B78-1152G, table 1); the reported $\mathrm{K}_{2} \mathrm{O}$ content for this sample is well below that typical for biotite and, conversely, very high for hornblende. As presented, the date must be considered suspect. No similar age granitic rocks are known elsewhere in southwestern Alaska, but rocks of this age are common in the Alaska-Aleutian Range batholith to the east (Wilson and others, 2006b). Pluton originally mapped as part of map unit TKg by Hoare and Coonrad (1978)

\section{TOGIAK-TIKCHIK COMPLEX}

MzPzt Togiak-Tikchik Complex, undivided (Lower Cretaceous to Lower Paleozoic) — Thick, marine unit consisting of volcanic and sedimentary rocks including pillow basalts, intermediate to mafic flows, breccia, crystal-lithic tuff, thin-bedded to massive tuffaceous chert and siltstone, argillite, graywacke, pebble-cobble conglomerate, and limestone. Formerly called the Gemuk Group (Hoare and Coonrad, 1959a, 1961a,b), this unit consists of a wide variety of rock types in a structural collage of blocks. The Gemuk Group as originally defined consists chiefly of dense, dark, massive siltstone having interbeds of chert, volcanic rocks, limestone, graywacke, and breccia (Cady and others, 1955). The assemblage was subsequently redefined as the Togiak-Tikchik Complex on the basis of its structural character (Wilson and Coonrad, 2005). Unit crops out in a wide belt through the Goodnews Bay quadrangle from the Eek Mountains in the north southwest to Goodnews Bay making up most of the northwestern Ahklun Mountains. It is unconformably overlain by rocks of the Late Cretaceous Kuskokwim Group (Kk and Kkn) and Early Cretaceous (Valanginian) calcareous graywacke and siltstone $(\mathrm{Kcgc})$. Permian limestone $(\mathrm{PI})$ containing Atomodesma sp. is interbedded throughout the unit. Hoare and Coonrad (1978, see also www.alaskafossil.org) collected samples containing corals of Permian age and crinoids, bryozoans, and Halobia of Triassic age. They also collected brachiopods (including several productoid forms, cleiothyridinoid genus, and a spiriferoid), a pleurotomarian gastropod, and pelecypods of late Paleozoic (probably Permian) age. Hoare and Coonrad (1978) mentioned the unit contains volcanic rocks of Triassic, Permian, and Devonian ages. Unit was included in the Goodnews terrane by Box (1985a) and Box and others (1993); however, rocks also mapped as unit $\mathrm{MzP}_{\mathbf{z}}$ by Hoare and Coonrad (1978) and included in the Togiak-Tikchik Complex were assigned to the Togiak terrane by Box and others (1993; see also Decker and others, 1994). Unit was subdivided by Box (1985a) in the Hagemeister Island and southernmost of the Goodnews Bay quadrangles into units JRCs (JPCs, herein), Jkmvs (JPmvs, herein), Jkmb (JPmb, herein), Pvs, and Pmv. Where possible, subunit assignments were extrapolated from the Box (1985a) map area into the Hoare and Coonrad (1978) map area. Unit MzPz of Hoare and Coonrad (1978) was further subdivided into two mélange units (MzPa; Mzm) by Box and others (1993) in the Bethel quadrangle. Included rock packages are the following:

Mzm Mélange (Mesozoic)_-Mélange containing chert, cherty tuff, siliceous siltstone, limestone and dolostone, pillowed and massive basalt, gabbro, and graywacke in an argillite matrix (Box and others, 1993; Hoare and Jones, 1981; Wilson and others, 2006b). Chert was described by Hoare and Jones (1981) as gray and thin bedded with shale partings or red, siliceous silt and massive or thick bedded, gray, black, white and brownish. They also described calcareous sandstone and shale, white crystalline limestone, and pyroclastic rocks altered to greenstone. Consists of unit kPzm of Box and others (1993) in the Bethel quadrangle and subdivided from unit MzPz of Hoare and Coonrad (1978) in the Goodnews Bay and adjacent Dillingham and Taylor Mountains quadrangles based on work reported in Wilson and others (2006b). Unit crops out in the Tikchik Lakes area of the Bethel and Goodnews Bay quadrangles and extends into the adjacent Taylor Mountains and Dillingham quadrangles. The mélange may contain rocks of multiple map units, including the argillite and graywacke (KKag), volcanic rock ( $P v$ and $k v$ ), clastic rocks (Pcs), limestone (PIs), greenstone and schist (MDv), and chert (PzC and KPzC) of Wilson and others (2006b). Unit is structurally complex and is dismembered along anastomosing cleavage (Box and others, 1993). According to Hoare 
and Jones (1981) "the rocks were deformed twice by isoclinal folding and offset by northwest trending high-angle faults and northwest-dipping low- and high-angle reverse faults. The older folds trend west or northwest; the younger folds are post-Cretaceous in age, trend northeast, and are commonly recumbent to the southeast." Unit structurally underlies greenstone and schist (MDv) to the northwest beneath a low-angle(?) fault and is juxtaposed against volcanic and sedimentary rocks (KKvs) along the high-angle Togiak-Tikchik Fault (Box and others, 1993). Units that can be distinguished, such as the limestone of Permian age are mapped separately. Reported are Late Triassic and Permian megafossils and radiolarians of Paleozoic(?), Devonian, pre-Late Devonian, and Triassic age including the radiolarians Eucyrtis sp., Mirifusus(?), Parvicingula blowi Pessagno, Parvicingula sp., Ristola(?) altissima Rust, Ristola sp., and Spongocapsula sp.(?) of Early Cretaceous (Berriasian/early Valanginian) to Late Jurassic (late Tithonian) age, and conodonts Epigondolella, Epigondolella abneptis, Neogondolella, Neogondolella navicula, Xaniognathus sp. indet, of Late Triassic, Norian age (Hoare and Jones, 1981; Box and others, 1993; see www.alaskafossil. org). Unit was included in the Tikchik terrane by Box and others (1993)

JKp Phyllite and chert (Lower Jurassic and Upper Triassic?) - Gray, green, and black phyllite, fine-grained tuff, and tuffaceous chert (Box and others, 1993). Unit crops out in the southeast corner of the Bethel quadrangle near the heads of Upnuk and Chikuminuk Lakes and trends north-northeast where it continues into the adjacent Taylor Mountains quadrangle. Unit depositionally overlies map unit $\mathrm{Kb}$ in the southeastern Bethel quadrangle and is overlain by map units Jvs and Ja (Box, 1985a). Box and others (1993) constrained age based on unit overlying $\mathrm{kb}$ and an Early Jurassic age derived from the single radiolarian collection. On the basis of field notes of J.M. Hoare and W.H. Condon, in the adjacent Taylor Mountains quadrangle, the unit could also be described as gray to black cherty phyllitic shale, highly contorted thin-bedded siliceous argillite and local cherty dark calcareous phyllite in association with greenstone of map unit MDv. The phyllite is locally sulfide-bearing along fault zones according to the field notes of J.M. Hoare and W.H. Condon (USGS, unpub. data, 1969, 1970)

Kvs Volcanic and sedimentary rocks (Upper Triassic) - "Marine unit consisting of chert, tuffaceous cherty rocks, argillite, siltstone, volcanic wackes, conglomerate, limestone, and mafic flows and breccias" (Hoare and Coonrad, 1978). Limestone is generally white to cream colored and recrystallized; however, it locally may be dark gray and finely crystalline. Possibly occurs in fault-bounded settings. Unit crops out in two areas: near the head of Lake Chauekuktuli in the northeast corner of the Goodnews Bay and adjacent Dillingham quadrangles and also near where the Kanektok River has cut through the Ahklun Mountains. Fossils include the ammonite Arcestes sp. of Late Triassic age and pelecypods Monotis subcircularis Gabb and Monotis(?) sp. of Norian age (see www.alaskafossil.org). Similar rocks are included in the $\mathrm{MzP}$ unit of Hoare and Coonrad (1978, unit MzPzt, herein) as well as in the $\mathrm{KP} z \mathrm{~m}$ melange unit of Box and others (1993, unit Mzm in part, herein). Hoare and Coonrad (1978) mapped these rocks as a separate unit only in the vicinity of fossil localities "because the rocks resemble other rocks of Paleozoic and Mesozoic ages with which they are tectonically associated." Unit included both in the Goodnews and Tikchik terranes by Box and others (1993)

Kv Basalt and chert (Upper Triassic) - "Massive and pillow basalt and basaltic breccia interbedded with thin-bedded tuffaceous chert and shale" (Box and others, 1993). Unit crops out near the heads of Upnuk and Nishlik Lakes along the southwestern edge of the Bethel quadrangle and continues eastward into the adjacent Taylor Mountains quadrangle. West of Milk Creek Fault, hydrothermally altered basalt contains secondary chlorite, quartz, and calcite but retains original subophitic and fine-grained plagioclase porphyritic textures (Box and others, 1993). East of Milk Creek Fault, a strong foliation and recrystallization has produced fine-grained schist or phyllite composed of chlorite, epidote, calcite, and pumpellyite (Box and others, 1993). "Whole-rock trace-element chemistry is characterized by flat to light REE-depleted chondrite-normalized REE pattern, and by high La/Nb elemental ratios, characteristic of island-arc tholeiitic basalts" (Box and others, 1993). Box and others (1993) linked the units on either side of the Milk Creek Fault on the basis of similar stratigraphic position and trace-element chemistry. Box and others (1993) reported interbedded shale yielded pelecypods of Late Triassic age just east of Aniak Lake as well as in the Taylor Mountain quadrangle east of map area (W.L. Coonrad, written commun., 1991, cited in Box 
and others, 1993). In the Taylor Mountains quadrangle, unit is associated with a limestone that yields Monotis and Halobia fossils of Late Triassic age (Wilson and others, 2006b). Unit was included in the Togiak terrane by Box and others (1993)

MzPa Argillaceous mélange (Mesozoic to Paleozoic)—Rock unit described by Box and others (1993) as a weakly to intensely fractured foliated black to green argillaceous mélange containing discontinuous phacoids of radiolarian chert, limey sandstone, blocks of limestone, and subphyllitic, amygdaloidal basalt. Unit crops out in the Eek Mountains near the southern boundary of the Bethel quadrangle. Unit is unconformably overlain by Cretaceous rocks of the Kuskokwim Group (Kk) and calcareous graywacke and siltstone (Kcgc). Conodonts Neogondolella bitteri and Neogondolella phosphoriensis of Permian age were found in limy siltstone (Box and others, 1993; see also www.alaskafossil.org). Box and others (1993) reported Permian pelecypods (Atomodesma sp. fragments) from a basalt-limestone block originally reported by Murphy (1989) and Permian conodonts recovered from limy siltstone in the matrix of the unit. Unit was included in the Goodnews terrane by Box and others (1993)

Pv Volcanic rocks (Permian)_Pillow and columnar-jointed amygdaloidal, mildly altered basalt flows, breccia, diabasic intrusive, and a few sandy tuffs; unit Pb of Box (1985a) and Pv of Hoare and Coonrad (1978). Unit crops out near Goodnews Bay and north of Nuyakuk Lake. In the Goodnews Bay area, unit is interbedded with volcaniclastic sedimentary rocks (unit Pvs herein; Box, 1985a). Hoare and Coonrad (1978) did not separate these rocks from their undivided $\mathrm{MzP}$ unit in the vicinity of Goodnews Bay. In the Nuyakuk Lake area, unit lies stratigraphically above and grades downward into the Permian limestone (unit Pls herein; Mertie, 1938, p. 45-46). Near lowest part of section north of Nuyakuk Lake, fossils identified in an interbed or fault sliver of limestone include brachiopods Calliprotonia sp., Neochonetes(?), Neophricadothyris sp., Neospirifer(?) sp., Thamnosia sp., Waagenoconcha(?) sp., and Yakovlevia sp. of Permian age; foraminifera Schwagerina jenkinsi Thorsteinnson of Permian age; stenoporoid bryozoans of Permian age; and echinoderm debris of Permian age (see sample 79AHr 2, www.alaskafossil.org). Outcrops in vicinity of Goodnews Bay were included in the Goodnews terrane by Box (1985a); outcrops near Nuyakuk Lake lie within his Togiak terrane

Pls Limestone (Permian) - Thin-bedded and massive, light- to dark-gray, locally cream-colored, fine-grained, recrystallized limestone; unit PI of Hoare and Coonrad (1978) and Box (1985a). Tuffaceous and locally cherty; unit has a fetid odor upon breaking (Hoare and Coonrad 1978; Box, 1985a). Unit is widely distributed throughout the map area and is commonly intercalated in the Togiak-Tikchik Complex and mélange units (MzPzt, MzPza, Mzm). Hoare and Coonrad (1978) reported the unit "commonly closely associated with mafic volcanic rocks into which it grades through medium of calcareous breccias and tuffs." Commonly contains the pelecypod Atomodesma of Permian age as well as crinoid stems, brachiopods, other pelecypods, and possible bryozoan reported (J.M. Hoare and W.H. Condon, unpub. data; Box, 1985a; see also www.alaskafossil.org). Unit included in the Goodnews terrane by Box (1985a); however, rocks of this unit are also found within his Togiak terrane (Box and others, 1993; Decker and others, 1994)

Pvs Volcaniclastic sedimentary rocks (Permian)_-"Volcaniclastic sedimentary rocks, ranging from coarsely bedded volcanic breccias to finely bedded calcareous tuffaceous rocks. Limestone cobble conglomerate locally north of Goodnews Bay. Red to black laminated argillite with radiolarian ghosts locally north and east of Goodnews Bay. Age constrained by several occurrences of fragmentary Atomodesma sp. Prehnite-pumpellyite facies" (Box, 1985a). Interbedded with Permian mafic volcanic rocks (Pv). Unit included in the Platinum subterrane of the Goodnews terrane by Box (1985a); however, rocks that are similar and stratigraphically correlated are found in the western Taylor Mountains quadrangle associated with map units Pls and PV and apparently extend into the eastern Bethel quadrangle (map unit Pcs of Wilson and others, 2006b). These rocks were assigned to the Togiak terrane by Box (1985a)

Pcs Clastic rocks (Permian?)_-WWell-bedded, cleaved sandstone, shale, thin limestone interbeds, and cobble conglomerate $* * *$ sandstone and conglomerate are composed predominantly of chert clasts (containing radiolarian ghosts and internal quartz veins) and minor phyllite and porphyritic volcanic clasts; shale-rich section have thin limestone turbidite beds and thin sand to gravel beds of volcaniclastic composition" (Box and others, 1993). Unit crops out 
in the Bethel quadrangle north and south of the head of Upnuk Lake and extends outside the map area into the adjacent Taylor Mountains quadrangle where it is mapped as the clastic rocks unit (Pcs) of Wilson and others (2006b). Unit depositionally overlies the greenstone and schist unit (MDv) (Box and others, 1993). Permian limestone (PIs) is interbedded with this unit in many places in the Taylor Mountains quadrangle to the east (Wilson and others, 2006b). Conodonts of Middle(?) Triassic and Early Mississippian to Late Devonian age were reported by Box and others (1993). With respect to the Devonian conodonts, Anita Harris (USGS, written commun., 1989) suggested they may have been derived from redeposited clasts or "interweaved" tectonic slices (see comments for sample 87AMM 69 at www.alaskafossil.org). Unit was included in the Tikchik terrane by Box and others (1993)

MDv Greenstone and schist (Lower Mississippian or Upper Devonian) - Box and others (1993) described this unit as consisting of "Weakly to moderately foliated and flattened pillowed and massive basalt, andesite, dacite, rhyolite flows, and breccia with greenschist metamorphicmineral assemblages." They also stated that the rocks that have a volcanic protolith have whole-rock trace-element signatures indicating an arc-alkaline arc affinity. In the adjacent Taylor Mountains quadrangle, Wilson and others (2006b) described "Fine- to coarse-grained, massive green to purple altered greenstone, occasionally calcareous or schistose, rarely interbedded with green chert, argillite, and tuff. Greenschist with occasional chert boudins is a minor part of unit as is shale-chip agglomerate. Greenstone is locally cut by quartz and calcite veins containing epidote and copper sulfides" based on the 1969 and 1970 field notes of J.M. Hoare and W.H. Condon. Unit crops out near the head of Chikuminuk Lake. Unit is interbedded with the basal part of unit Pcs; clastic rocks and phyllite of map unit Jkp may overlie this map unit (Wilson and others, 2006b). Age inferred by Box and others (1993) on the basis of conodonts of Late Devonian to Early Mississippian age near the base of unit shown herein as Pcs (note, the Pcs unit was mapped as Triassic to Devonian age by Box and others, 1993). Age assignment questionable because conodont-bearing samples may have been collected from redeposited clasts or "interweaved" tectonic slices (see comments by Anita Harris for sample 87AMM 69, www.alaskafossil.org). Unit may be Permian in age because of association with clastic rocks of presumed Permian age owing to association with Permian limestone (PIs) interbeds in the Taylor Mountains quadrangle (Wilson and others, 2006b). Unit included in the Tikchik terrane by Box and others (1993)

DOI Thin-bedded limestone (Devonian to Ordovician) - “Thin-bedded to massive, fine-grained gray limestone, highly fractured and veined with white calcite, contains algal reefs and reef breccias. Locally contains interbedded tuffs and mafic volcanic rocks. Recrystallized to marble with interbedded quartzite and quartz-chlorite schist ***" (Hoare and Coonrad, 1978). Algal mounds indicate shallow water deposition (Decker and others, 1994). Unit is in scattered outcrops along a north-northeasterly trend from Goodnews Bay to the northern edge of the Goodnews Bay quadrangle. Unit thrust over Permian limestone (PIs) and calcareous schist unit (KPcs) and intruded by gabbro of Jurassic age (Jgb). Hoare and Coonrad (1978) reported sparse fossils of Middle Devonian to Early(?) Ordovician age. One sample collected by Stephen Box in northern part of Goodnews Bay quadrangle contains the conodonts Acanthodus lineatus (Furnish), Drepanoistodus sp., Variabiliconus bassleri (Furnish), "Scolopodus" cf. "S." sulcatus Furnish, Eucharodus parallelus (Branson and Mehl), and Rossodus(?) sp. of Early Ordovician age (see sample 89AJM 60a, www.alaskafossil.org). A sample collected by J.M. Hoare contained ostracodes, echinoderms, fragments of brachiopods, algae, and small colonies of tabulate coral, possibly the genus Dania of Silurian age (A.K. Armstrong, written commun., 1975). Unit was included in the Goodnews terrane by Box (1985a)

\section{METAMORPHIC ROCKS OF THE TOGIAK-TIKCHIK COMPLEX}

[In general, where stratigraphic position is reported, this is the inferred stratigraphic position for the protolith; where age is reported, this is the metamorphic age of the unit]

\section{Rock units of the Kisaralik anticlinorium of Box and others (1993) (Mesozoic and (or)} Paleozoic) - A structurally imbricate package of Mesozoic to Paleozoic deep-marine sedimentary and mafic volcanic rocks (Box and others, 1993). Units listed here are in structural 
order in the anticlinorium, top to bottom. Unless otherwise noted, the following unit descriptions are quoted from Box and others (1993)

$\mathrm{MzP}$ Metachert and phyllitic metachert- "Finely crystalline, thin-bedded quartzites (metachert) and finely interlayered quartzite and black phyllite. Found east of southern part of Greenstone Ridge in central part of map area [Bethel quadrangle]. Composed of fine aggregates of quartz with seams to centimeter-thick bands rich in fine-grained white mica. Recrystallized radiolarian tests present in some horizons. Thickness is uncertain. Structurally overlies units $\mathrm{MzP}_{z} \mathrm{~S}$ and $\mathrm{Mz} \mathrm{P}_{\mathrm{z}}$ on north and is structurally overlain by unit MDm on south. Unconformably overlain by conglomeratic rocks [Kkn] of Kuskokwim Group along Kisaralik River. Age constrained by presence of radiolarians (Phanerozoic) and by late Early Cretaceous age of overlying unit [Kkn]." Unit is strongly foliated and metamorphosed to greenschist and transitional greenschist-blueschist facies

MzPs Arkosic sandstone and slate-"Strongly cleaved, medium-grained, generally thin-bedded, arkosic sandstone and slate. Exposed on prominent ridge east of Greenstone Ridge in central part of map area [Bethel quadrangle]. Detrital grains in sandstones include monocrystalline quartz (30 to 50 percent), plagioclase (10 percent), and potassium feldspar (5 percent), and minor mica, slate, and volcanic rock fragments. Alteration products include secondary prehnite, calcite, quartz, and white mica. Turbidite depositional features locally preserved. Thickness is uncertain. Intercalated (structurally?) over 100-m-thick zones with thin-bedded chert-argillite sections ( $\mathrm{Mz} \mathrm{Pzm})$; unconformably overlain by conglomeratic rocks [Kkn] of Kuskokwim Group. Age is uncertain, but older than Late [Early] Cretaceous age of unit [Kkn]." Unit has a slaty cleavage and is metamorphosed to the prehnite-pumpellyite facies (Box and others, 1993)

$\mathrm{Mz} \mathrm{P}_{\mathrm{Z}} \quad$ Volcaniclastic sandstone and argillite - "Turbiditic, thin-bedded, medium- to fine-grained, volcaniclastic sandstones, and dark-green to black argillites with weak to nonexistent slaty cleavage. Exposed along prominent ridge east of Greenstone Ridge in central part of map area [Bethel quadrangle]. Detrital grains include volcanic rock fragments containing plagioclase phenocrysts, plagioclase, and minor potassium feldspar, clinopyroxene, and quartz. Thickness is uncertain. Structurally overlain and underlain by unit MzPzs; structurally overlain by unit $\mathrm{MzP}$ m along Kisaralik River; unconformably overlain by conglomeratic strata [Kkn] of Kuskokwim Group north of Kisaralik River. Age is uncertain, but older than Late [Early] Cretaceous age of unit [Kkn]." Unit has a slaty cleavage and is metamorphosed to the prehnite-pumpellyite facies (Box and others, 1993)

$\mathrm{MzPzC} \quad$ Chert and argillite- "White, gray-green, and blue-green crystallized chert in 2- to 5-cmthick beds interbedded with black to dark-green phyllite or slate beds of similar thickness. Exposed on prominent ridge east of Greenstone Ridge in central part of map area [Bethel quadrangle]. Structurally(?) intercalated with unit MzPzs; unconformably overlain by conglomeratic rocks [Kkn] of Kuskokwim Group. Age constrained by presence of recrystallized radiolarian (Phanerozoic) and Late [Early] Cretaceous age of overlying unit [Kkn]." Unit has a slaty cleavage and is metamorphosed to the prehnite-pumpellyite facies (Box and others, 1993)

MzPzp Chloritic phyllite- "Relatively homogenous unit of finely foliated and crenulated phyllite $* * *$. Found east of southern part of Greenstone Ridge in south-central part of the map area [Bethel quadrangle]. Protolith was probably fine-grained tuffaceous sediment of uncertain age. Whole-rock major- and trace-element chemical compositions are similar to those of modern mid-ocean ridge basalts and strikingly similar to those of lavas from unit $\mathrm{MzP}_{2} \mathrm{~b}$. Structurally overlies unit MDm and is intruded by serpentinite (Ksp). Depositionally overlain by conglomeratic rocks [Kkn] of Kuskokwim Group. Age is uncertain, but older than Late Cretaceous age of unit [Kkn]." Unit is strongly foliated and metamorphosed to greenschist and transitional greenschist-blueschist facies. (Note, on this map, the Kuskokwim Group nearshore facies rocks of map unit Kkn are assigned an age that includes Albian or late Early Cretaceous)

MDm Marble and metabasaltic dikes (Lower Mississippian and (or) Upper Devonian)_-"Lightgray to white calcitic and dolomitic marble cut by pre-metamorphic basaltic dikes. Only found in small area east of Greenstone Ridge in central part of map area [Bethel quadrangle]. Locally contains as much as 20 percent clastic grains of feldspar, quartz, and plutonic rock fragments. Rare metamorphic blue amphiboles (magnesioriebeckite) in metabasaltic dikes indicate relatively high-pressure, low-temperature metamorphism (Sarah Roeske, 
written commun., 1988). Ranges from 100 to $300 \mathrm{~m}$ thick. Unit found structurally above unit $\mathrm{MzP}_{z} \mathrm{~m}$ and structurally below unit $\mathrm{M}_{z} \mathrm{P}_{z}$; original depositional relations are uncertain. Age constrained by conodonts of latest Devonian to earliest Mississippian age" (Stephen Box and others, unpub. data, reported in Box and others, 1993). Unit is strongly foliated and metamorphosed to greenschist and transitional greenschist-blueschist facies

Jgs Green amphibole-bearing schist (Late Jurassic)—Schist recrystallized in part to greenschist metamorphic facies mineral assemblage of albite-epidote-chlorite-actinolite. Schist contains interbeds of thin-bedded, white or green, meta-chert having white mica-rich laminae (Box and others, 1993); overlain by crystalline limestone, phyllite, and minor amounts of chlorite, graphite, and quartz-sericite schist (Hoare and Coonrad, 1959a). Mapped as Mesozoic to Paleozoic metabasalt and minor meta-chert (MzPzb) by Box and others (1993); protolith was diabase and basalt having MORB trace-element (REE) signature (Box and others, 1993). Although protolith age is unknown, it was suggested to be Devonian to Ordovician by Hoare and Coonrad (1959a). Greenstone Ridge near the center of the Bethel quadrangle is composed of this map unit. Unit is bounded on west by Golden Gate Fault; nearshore facies Kuskokwim Group rocks (Kkn) depositionally overlie unit at the north end of its exposure. Age of metamorphism may be Late Jurassic based on 146.0 \pm 15.0 Ma age of actinolite (sample B78-1213, table 1). Unit was included in the Goodnews terrane by Box and others (1993)

KPmb Metabasaltic schist (Triassic? to Permian?)-Partially to completely recrystallized schistose rocks derived from mafic igneous and associated sedimentary rocks, including pillow basalt, angular volcanic breccia, pebbly mudstone, fine-grained tuffaceous sedimentary rocks, diabase, gabbro, and rare chert (Box, 1985a). Mineral assemblages indicate greenschist to transitional greenschist-blueschist facies metamorphism (Box, 1985a). Unit crops out on the south and west side of Goodnews Bay and near Cape Pierce. Low-angle faults separate unit from overlying nonfoliated mafic rocks (ophiolite units kob, kod, kog) and from underlying schistose clastic rocks ( $\mathrm{kPvs}$ ). Schistose fabrics indicative of multiple deformation events include moderately to shallowly dipping foliation and a locally developed lineation; sporadically developed crenulation cleavage and crenulation microfolds; and northeast-trending open folds folding both deformation fabrics (Box, 1985a). Metamorphic fabric is similar to that of structurally underlying meta-volcaniclastic glaucophanehornblende epidote schist ( $\mathrm{kPvs}$ ) and calcareous schist (KPcs) (Box, 1985a). Similarity of metamorphic fabrics suggests all three units were deformed during the same event (Box, 1985a). West of Goodnews Bay, the unit structurally overlies Permian volcaniclastic rocks (Pvs) and underlies Permian limestone (PIs). Metamorphic age is between Middle Jurassic and Middle Triassic based on age constraints as described for unit KPvs below. Intruded by nonfoliated Middle Jurassic hornblende gabbro (Jgb). Schist yielded K-Ar mica ages of $150 \pm 8$ and $155 \pm 8 \mathrm{Ma}$ (table 1), possibly related to a Late Jurassic thermal event suggested by Box (1985a); however, the ages are suspect because the $\mathrm{K}_{2} \mathrm{O}$ content of the mica (2.94 and 1.71 percent) is much lower than typical for mica ( 8 to 10 percent), suggesting alteration. Box (1985a) suggests the protolith age is similar to the structurally overlying ophiolite (units kob, kod, and kog) because of the lithologic similarity of the protolith. However, on the basis of Box's (1985a) terrane model, the similarity of protolith may not be relevant, as he assigned this unit to his Goodnews terrane and the ophiolite to his Togiak terrane. An alternative protolith age assignment could be Permian or older, based on metamorphic ties to unit KPvs and association with Permian rocks of the Goodnews terrane

kPvs Volcaniclastic glaucophane-hornblende-epidote schist (Triassic? to Permian?) —Metamorphosed conglomerate, sandstone, and shale. Unit includes map units Jkmvss and JPvss of Box (1985a), which he reports grade together in the vicinity of Goodnews Bay. Protolith for both was derived from a feldspar-rich volcanic source (Box, 1985a). Rounded cobble metaconglomerate contains mostly plagioclase-phyric amygdaloidal volcanic clasts (Box, 1985a). Mineral assemblages indicate greenschist to transitional greenschist-blueschist facies metamorphism (Box, 1985a). Unit shows evidence of multiple metamorphic events and has a more pronounced structural fabric to the southwest (Box, 1985a). The latest metamorphic event created a strong fabric by syn-metamorphic flattening or mylonitization and a lineation formed by clast elongation and mineral alignment (Box, 1985a). This latest metamorphic fabric deformed non-coplanar isoclinal folds and slaty cleavage of a previous metamorphic event (Box, 1985a). Metamorphic fabric is similar to the structurally overlying metabasaltic schist ( $\mathrm{kPmb}$ ) and underlying calcareous schist ( $\mathrm{RPCs}$ ) suggesting all three units were 
deformed during the same Late Jurassic metamorphic event (Box, 1985a). However, this is contradicted by K-Ar cooling age of amphibole of $231.2 \pm 6.9 \mathrm{Ma}$ (sample 82SB-147, table 1) suggesting Middle Triassic metamorphism; age is constrained to be older than the intrusion of Middle Jurassic gabbroic rocks (unit Jgb). On and adjacent to Susie Mountain, unit is intruded by pyroxenite and hornblende gabbro bodies which yielded Middle Jurassic K-Ar amphibole ages. Box (1985a) indicates unit structurally overlies Permian mafic volcanic rocks (Pv) and volcaniclastic rocks (Pcs), which he concludes suggests the protolith age could be as old as Permian. Unit crops out near Cape Pierce and on the south and west sides of Goodnews Bay. Unit was included in the Cape Pierce subterrane of the Goodnews terrane by Box (1985a)

kPcs Calcareous schist (Triassic? to Permian?)—Recrystallized schistose and phyllitic calcareous sandstone, shale, limestone, limestone conglomerate, greenish tuffaceous rocks, mafic volcanic rocks, and volcanic conglomerate. Includes units Jkmc of Box (1985a) and Pzcs of Hoare and Coonrad (1978). Turbidite characteristics are locally preserved in clastic metasedimentary rocks (Box, 1985a). Mineral assemblages indicate greenschist to transitional greenschist-blueschist facies metamorphism (Box, 1985a); however, structurally the unit shows evidence of multiple metamorphic events (Box, 1985a). The latest metamorphic event created a strong fabric by syn-metamorphic flattening or mylonitization and a lineation formed by clast elongation and mineral alignment (Box, 1985a). This latest metamorphic fabric deformed tight folds and axial planar slaty cleavage of a previous deformation event (Box, 1985a). Metamorphic fabric is similar to the structurally overlying metavolcaniclastic glaucophane-hornblende epidote schist (KPvs) and metabasaltic schist (下Pmb) suggesting all three units were deformed during the same metamorphic events (Box, 1985a). Metamorphic age is constrained as described above for unit KPvs. Unit crops out in two locations, near Cape Pierce and near Jacksmith Bay. Near Jacksmith Bay, unit is structurally overlain by Devonian to Ordovician limestone (DOI) and the Kanektok metamorphic complex (Ek and $\mathrm{Ekm}$ ). Intruded by nonfoliated Middle Jurassic gabbroic rocks (Jgb). Age of protolith may be Permian or older (Hoare and Coonrad, 1978; Box, 1985a) because of metamorphic ties to unit KPvs and association with Permian rocks of the Goodnews terrane. Unit was included in the Cape Pierce subterrane of the Goodnews terrane by Box (1985a)

Dismembered ophiolite of Box (1985a) (Lower Jurassic to Middle Triassic) - The following units were described by Box (1985a) and Decker and others (1994) as the Newenham ophiolite complex, a dismembered ophiolite. The defined ophiolite assemblage also included the serpentinized ultramafic rocks of Cape Newenham, which are here included in map unit Jum. Hoare and Coonrad (1978) mapped the trondhjemite as a distinct map unit, but included the remaining lithologies in their MzPz or Jum units. Box (1985a) placed these rocks in his Hagemeister subterrane of the Goodnews terrane. As described by Hoare and Coonrad (1978), little information is available about specific lithologies and their distribution in the $\mathrm{MzP}_{2}$ unit, hence the ophiolite may also occur outside of the area covered by Box's dissertation area and therefore be more extensive than shown. Box (1985a) inferred the igneous rocks of the complex to be cogenetic and inferred the ophiolite complex to be Late Triassic in age on the basis of the radiolaria in the included chert. Subdivided into the following:

Jkot Trondhjemite — Light-gray, medium-grained trondhjemite consisting of abundant quartz, plagioclase, and minor chlorite, sericite, and clinozoisite (Hoare and Coonrad, 1978; Box, 1985a). Found in small bodies mapped in a number of areas of the Hagemeister Island and Goodnews Bay quadrangles by Hoare and Coonrad (1978). Box (1985a) indicated that in addition to the mapped bodies, other small bodies occur within altered diabase near Cape Newenham. At Tokomarik Mountain, Box (1985a) described the trondhjemite as "a northeast-dipping slab faulted above and below against schistose rocks ***." Box (1985a) tentatively assigned a Late Triassic age based on what he thought was a probable co-genetic relation with the Upper Triassic pillow basalt (Kob) and other components of the ophiolite, whereas Hoare and Coonrad (1978) assigned a Jurassic age based on the association of the trondhjemite with Jurassic gabbro and ultramafic rocks

kob Pillow basalt (Triassic) - Aphanitic to porphyritic pillow basalt, containing interbedded pillow breccia, aquagene tuff, and inter-pillow and interbedded red and white radiolarian chert as described by Box (1985a). Porphyritic basalt has plagioclase and clinopyroxene phenocrysts in an intergranular to subophitic groundmass of plagioclase, clinopyroxene, and 
secondary replacement minerals. Basalt is commonly amygdaloidal; abundant vesicles are filled with a combination of chlorite, clinozoisite, prehnite, pumpellyite, and calcite. Box (1985a) reported a number of radiolarian collections; however, only two were age diagnostic, yielding Middle Triassic to Early Jurassic and Middle to Late Triassic ages. Box (1985a) considered the pillow basalt to be Late Triassic

kod Diabasic intrusive rocks (Triassic) - Subophitic, holocrystalline plagioclase-clinopyroxene diabase (Box, 1985a). Shown here west of Jagged Mountain at Cape Newenham, at Chagvan Mountain, on the coast south of Downdraft Mountain, and along the coast east of Cape Pierce; Box (1985a) also mapped 0.3- to 1.0-m-wide diabase sills and dikes containing basalt and chert screens west of Matogak River mouth, thick diabase sills intruding chert at Pyrite Point, and diabase dikes cutting gabbro south of Chagvan Bay, which are not shown. Box (1985a) described the unit as "mostly massive and highly altered to low greenschist facies assemblage." Unit is altered to hornblende hornfels west of Matogak River mouth, which Box (1985a) reported is due to an underlying, but not shown, gabbroic pluton; a K-Ar amphibole age on the hornfels was $187 \pm 10 \mathrm{Ma}$ (sample 81SB 116b, table 1). Unit believed to be cogenetic with associated, overlying Upper Triassic pillow basalt (Kob) (Box, 1985a)

kog Pyroxene gabbro (Triassic) - Altered clinopyroxene gabbro, locally containing up to 5 percent orthopyroxene, which is commonly kinked and fractured and locally rimmed or replaced by pale-green amphibole (Box, 1985a). Plagioclase partially to completely replaced by fine aggregate of albite, epidote, chlorite, calcite, and iron oxides. Compositional layering is rare in contrast to gabbro of map unit Jg. Locally grades into diabase ( $k o d)$ south at Chagvan Mountain due to increasing proportion of crosscutting diabasic dikes. Box (1985a) mapped gabbro as a thrust sheet above the Osviak Fault emplaced over schistose rocks of map unit KPCs around Security Cove and Cape Pierce. Locally, mylonite is found along contact and similar mylonite is found sporadically along contact between gabbro and structurally underlying diabase near Cape Newenham. Box (1985a) believed gabbro was co-genetic with associated diabase (Kod), pillow basalt (Kob), trondhjemite (Jkot) and serpentinized ultramafic rocks, all part of a dismembered ophiolite

Ek Kanektok metamorphic complex, undivided (Paleoproterozoic) - Gneiss and schist derived from sedimentary, volcanic, and plutonic rocks metamorphosed to upper greenschist through granulite facies (Hoare and Coonrad, 1978; Turner and others, 2009). "Includes mediumto coarse-grained, massive and well-foliated, biotite-hornblende gneisses, garnetiferous amphibolites, quartz-mica schists, and marble" (Hoare and Coonrad, 1978). It is an antiformal crystalline complex cored by high-grade orthogneiss intercalated with metavolcanic and metasedimentary rocks and flanked by greenschist-facies rocks (Turner and others, 2009). Rocks in core of complex include varieties of orthogneiss whose protoliths may have ranged in composition from granite to diorite (Turner and others, 2009; Moll-Stalcup and others, 1996). As described by Turner and others (2009), orthogneiss of the core is intercalated with pyroxene granulite, garnet amphibolite, garnet-mica schist (locally kyanite-bearing), and rare quartzite and marble (marble locally mapped separately as unit $\mathrm{Pkm}$ ). The core of amphibolite facies rocks apparently grade into greenschist facies rocks that dip away from the core on the northwest and southeast. These lower grade rocks contain a variety of schist and quartzite, as well as calc-phyllite, marble, and meta-conglomerate (Turner and others, 2009). Mineral foliation tends to parallel compositional layering and both consistently strike northeast; "dip of the foliation changes from northwest to southwest two to four times across the width of the complex" (Hoare and Coonrad, 1979) south of Kanektok River. Compositional layering and foliation are disrupted by northwest-trending faults including a significant left lateral offset at the Kanektok River. North of the river, the rocks are more highly deformed and the dip and trend of foliation are more variable (Hoare and Coonrad, 1979). The Kanektok metamorphic complex is fault bounded on the southeast against calcareous schist (unit KPcs), the Kuskokwim Group (unit Kk), and the undivided Togiak-Tikchik Complex (unit MzPzt) in the Goodnews Bay quadrangle and green amphibole-bearing schist (Jgs) in the Bethel quadrangle. The metamorphic complex is depositionally overlain by the Kuskokwim Group (unit Kkn) in the Bethel quadrangle. The Kanektok metamorphic complex crops out as a narrow belt trending northeast, extending from near Jacksmith Bay in the Goodnews Bay quadrangle northward $160 \mathrm{~km}$ to the southern part of the Bethel quadrangle. The Idono complex of Gemuts and others (1983; Miller and others, 1991; Miller and Bundtzen, 1994; Wilson and others, 1998) is similar in some respects to the Kanektok meta- 
morphic complex and crops out north of the map area in the Iditarod quadrangle. Locally subdivided into the following:

Ekm Marble - White, gray, and brownish garnetiferous marble generally associated with quartzose schist (Hoare and Coonrad, 1978). Mapped separately only where it forms the dominant rock unit; similar rocks also occur as thin, discontinuous bands in the lower grade marginal rocks of the complex and rarely in the high-grade core. Locally may contain incipient diopside, white mica, phlogopite, quartz, plagioclase, and epidote as minor phases (Turner and others, 2009)

um Unmapped - Small areas on Saint Matthew and Hall Islands that are not mapped

\section{References Cited}

Barth, T.F.W., 1956, Geology and petrology of the Pribilof Islands, Alaska: U.S. Geological Survey Bulletin 1028-F, scale $1: 63,360,160 \mathrm{p}$.

Box, S.E., 1982, Kanektok suture, SW Alaska; geometry, age, and relevance [abs.]: EOS, Transactions of the American Geophysical Union, v. 63, no. 45, p. 915.

Box, S.E., 1985a, Mesozoic tectonic evolution of the northern Bristol Bay region, southwestern Alaska: Santa Cruz, University of California, Ph.D. dissertation, $163 \mathrm{p}$.

Box, S.E., 1985b, Geologic setting of high-pressure metamorphic rocks, Cape Newenham area, southwestern Alaska, in Bartsch-Winkler, S., ed., The United States Geological Survey in Alaska-Accomplishments during 1984: U.S. Geological Survey Circular 967, p. 37-42.

Box, S.E., Moll-Stalcup, E.J., Wooden, J.L., and Bradshaw, J.Y., 1990, Kilbuck terrane; oldest known rocks in Alaska: Geology, v. 18, p. 1,219-1,222.

Box, S.E., Moll-Stalcup, E.J., Frost, T.P., and Murphy, J.M., 1993, Preliminary geologic map of the Bethel and southern Russian Mission quadrangles, southwestern Alaska: U.S. Geological Survey Miscellaneous Field Studies Map MF2226-A, scale 1:250,000.

Cady, W.M., Wallace, R.E., Hoare, J.M., and Webber, E.J., 1955, The central Kuskokwim region, Alaska: U.S. Geological Survey Professional Paper 268, 132 p., 9 pls. including 1 map, scale about 1:500,000.

Coonrad, W.L., 1957, Geologic reconnaissance in the YukonKuskokwim Delta region, Alaska: U.S. Geological Survey Miscellaneous Geologic Investigations Series Map I-223, scale 1:500,000.

Cox, Allan, and Dalrymple, G.B., 1967, Geomagnetic polarity epochs-Nunivak Island, Alaska: Earth and Planetary Science Letters, v. 3, no. 2, p. 173-177.

Cox, Allan, Doell, R.R., and Dalrymple, G.B., 1968, Radiometric time-scale for geomagnetic reversals: Quarterly Journal of the Geological Society of London, v. 124, pt. 1, no. 493, p. 53-66.

Cox, Allan, Hopkins, D.M., and Dalrymple, G.B., 1966, Geomagnetic polarity epochs-Pribilof Islands, Alaska: Geological Society of America Bulletin, v. 77, no. 9, p. 883-909.

Dalrymple, G.B., Cox, Allen, Doell, R.R., and Gromme, C.S., 1967, Pliocene geomagnetic polarity epochs: Earth and Planetary Science Letters, v. 2, p. 163-173.
Davis, A.S., Pickthorn, L.G., Vallier, T.L., and Marlow, M.S., 1989, Petrology and age of volcanic-arc rocks from the continental margin of the Bering Sea; implication for Early Eocene relocation of plate boundaries: Canadian Journal of Earth Sciences, v. 26, p. 1,474-1,490.

Decker, John, Bergman, S.C., Blodgett, R.B., Box, S.E., Bundtzen, T.K., Clough, J.G., Coonrad, W.L., Miller, M.L., Murphy, J.M., Robinson, M.S., and Wallace, W.K., 1994, Geology of southwestern Alaska, in Plafker, George, and Berg, H.C., eds., The geology of Alaska: Boulder Colorado, Geological Society of America, The geology of North America, v. G-1, p. 285-310.

Decker, John, Reifenstuhl, R.R., and Coonrad, W.L., 1984, Compilation of geologic data from the Russian Mission A-3 quadrangle, Alaska: Alaska Division of Geological and Geophysical Surveys Report of Investigations 84-19, 1 sheet, scale 1:63,360.

Elder, W.P., and Box, S.E., 1992, Late Cretaceous inoceramid bivalves of the Kuskokwim basin, southwestern Alaska, and their implications on basin evolution: The Paleontological Society Memoir 26, $39 \mathrm{p}$.

Faure, Gunter, and Mensing, T.M., 2005, Isotopes, principles and applications: Hoboken, New Jersey, U.S.A., John Wiley and Sons, $896 \mathrm{p}$.

Francis, D.M., 1976, Amphibole pyroxenite xenoliths; cumulate or replacement phenomena from the upper mantle, Nunivak Island, Alaska?: Contributions to Mineralogy and Petrology, v. 58, no. 1, p. 51-61.

Frost, T.P., Calzia, J.P., Kistler, R.W., and Vivit, D.V., 1988, Petrogenesis of the Crooked Mountains pluton, Bethel quadrangle, in Galloway, J.P., and Hamilton, T.D., eds., Geologic studies in Alaska by the U.S. Geological Survey during 1987: U.S. Geological Survey Circular 1016, p. 126-131.

Gemuts, I., Puchner, C.C., and Steffel, C.I., 1983, Regional geology and tectonic history of western Alaska, in Western Alaska geology and resource potential: Alaska Geological Society Journal, v. 3, p. 67-85.

Globerman, B.R., 1985, A paleomagnetic and geochemical study of Upper Cretaceous to lower Tertiary volcanic rocks from the Bristol Bay region, southwestern Alaska: Santa Cruz, University of California, Ph.D. dissertation, 292 p.

Hoare, J.M., and Condon, W.H., 1973, Lherzolite xenoliths in tholeiite, Nanwaksjiak Crater, Nunivak Island, Alaska [abs.]: Geological Society of America Abstracts with Programs, v. 5, no. 1, p. 55.

Hoare, J.M., Condon, W.H., Cox, Allan, and Dalrymple, G.B., 1968, Geology, paleomagnetism, and potassium-argon ages 
of basalts from Nunivak Island, Alaska, in Coats, R.R., Hay, R.L., and Anderson, C.A., eds., Studies in volcanology-A memoir in honor of Howel Williams: Geological Society of America Memoir 116, p. 337-413.

Hoare, J.M., and Coonrad, W.L., 1959a, Geology of the Bethel quadrangle, Alaska: U.S. Geological Survey Miscellaneous Geologic Investigations Map I-285, scale 1:250,000.

Hoare, J.M., and Coonrad, W.L., 1959b, Geology of the Russian Mission quadrangle, Alaska: U.S. Geological Survey Miscellaneous Geologic Investigations Series Map I-292, scale 1:250,000.

Hoare, J.M., and Coonrad, W.L., 1961a, Geologic map of the Hagemeister Island quadrangle, Alaska: U.S. Geological Survey Miscellaneous Investigations Series Map I-321, scale 1:250,000.

Hoare, J.M., and Coonrad, W.L., 1961b, Geologic map of Goodnews quadrangle, Alaska: U.S. Geological Survey Miscellaneous Geologic Investigations Map I-339, scale 1:250,000. [Quadrangle subsequently renamed to Goodnews Bay.]

Hoare, J.M, and Coonrad, W.L, 1978, Geologic map of the Goodnews Bay and Hagemeister Island quadrangles region, southwestern Alaska: U.S. Geological Survey Open-File Report 78-9-B, scale 1:250,000, 2 sheets.

Hoare, J.M., and Coonrad, W.L., 1979, The Kanektok metamorphic complex, a rootless belt of Precambrian rocks in southwestern Alaska, in Johnson, K.M., and Williams, J.R., eds., The United States Geological Survey in Alaska; accomplishments during 1978: U.S. Geological Survey Circular 804-B, p.72-74.

Hoare, J.M., and Coonrad, W.L., 1980, The Togiak Basalt, a new Formation in southwestern Alaska: U.S. Geological Survey Bulletin 1482-C, 11 p.

Hoare, J.M., and Coonrad, W.L., 1983, Graywacke of Buchia Ridge and correlative Lower Cretaceous rocks in the Goodnews Bay and Bethel quadrangles, southwestern Alaska: U.S. Geological Survey Bulletin 1529-C, 17 p.

Hoare, J.M., Coonrad, W.L., Detterman, R.L., and Jones, D.L., 1975, Preliminary geologic map of the Goodnews A-3 quadrangle and parts of the A-2 and B-2 quadrangles, Alaska: U.S. Geological Survey Open-File Report 75-308, $16 \mathrm{p}$.

Hoare, J.M., Coonrad, W.L., and McCoy, Scott, 1983, Summit Island Formation, a new Upper Cretaceous formation in southwestern Alaska: U.S. Geological Survey Bulletin 1529-B, $18 \mathrm{p}$.

Hoare, J.M., and Jones, D.L., 1981, Lower Paleozoic radiolarian chert and associated rocks in the Tikchik Lakes area, southwestern Alaska, in Albert, N.R.D., and Hudson, Travis, eds., The U.S. Geological Survey in AlaskaAccomplishments during 1979: U.S. Geological Survey Circular 823-B, p. 44-45.

Hopkins, D.M., and Silberman, M.L., 1978, Potassium-argon ages of basement rocks from Saint George Island, Alaska: U.S. Geological Survey Journal of Research, v. 6, no. 4, p. 435-438.

Hudson, Travis, 2001, Alaska resource data file-Hagemeister Island quadrangle: U.S. Geological Survey Open-File
Report 01-269, 78 p. (Available at http://ardf.wr.usgs.gov/ ardf_data/HG.pdf.)

Iriondo, Alexander, Kunk, M.J., and Wilson, F.H., 2003, ${ }^{40} \mathrm{Ar} /{ }^{39} \mathrm{Ar}$ geochronology of igneous rocks in the Taylor Mountains and Dillingham quadrangles in SW Alaska: U.S. Geological Survey Open-File Report 03-421, 32 p.

Jones, D.L., and Silberling, N.J., 1979, Mesozoic stratigraphy; the key to tectonic analysis of southern and central Alaska: U.S. Geological Survey Open-File Report 79-1200, 41 p.

Jones, D.L., Silberling, N.J., Berg, H.C., and Plafker, George, 1981, Map showing tectonostratigraphic terranes of Alaska, columnar sections, and summary description of terranes: U.S. Geological Survey Open-File Report 81-792, 20 p., 2 sheets, scale 1:2,500,000.

Kaufman, D.S., Hu, F.S., Briner, J.P., Werner, Al, Finney, B.P., and Gregory-Eaves, Irene, 2003, A 33,000 year record of environmental change from Arolik Lake, Ahklun Mountains, Alaska, USA: Journal of Paleoclimnology, v. 30, p. 343-362.

Kaufman, D.S., and Manley, W.F., 2004, Pleistocene maximum and Late Wisconsinan glacier extents across Alaska, U.S.A., in Ehlers, J., and Gibbard, P.L., eds., Quaternary glaciations - extent and chronology, Part II: North America: Amsterdam, Elsevier, Developments in quaternary Science, v. 2, p. 9-27.

Kaufman, D.S., Manley, W.F., Forman, S.L., and Layer, P.W., 2001a, Pre-late Wisconsin glacial history, coastal Ahklun Mountains, southwestern Alaska — new amino acid, thermoluminescence, and ${ }^{40} \mathrm{Ar} /{ }^{39} \mathrm{Ar}$ results: Quaternary Science Reviews, v. 20, p. 337-352.

Kaufman, D.S., Manley, W.F., Wolfe, A.P., Hu, F.S., Preece, S.J., Westgate, J.A., and Forman, S.L., 2001b, The last interglacial to glacial transition, Togiak Bay, southwestern Alaska: Quaternary Research, v. 55, p. 190-202.

Kilburn, J.E., Goldfarb, R.J., Griscom, Andrew, Box, S.E., 1993, Map showing metallic mineral resource potential in the Goodnews Bay, Hagemeister Island, and Nushagak Bay $1^{\circ}$ by $3^{\circ}$ quadrangles, southwest Alaska: U.S. Geological Survey Miscellaneous Field Studies Map MF-2228, 4 sheets, scale 1:250,000.

Lea, P.D., 1989, Quaternary environments and depositional systems of the Nushagak lowland, southwestern Alaska: Boulder, University of Colorado, Ph.D. dissertation, 355 p.

Lea, P.D., Elias, S.A., and Short, S.K., 1991, Stratigraphy and paleoenvironments of Pleistocene nonglacial deposits in the southern Nushagak Lowland, southwestern Alaska, U.S.A.: Arctic and Alpine Research, v. 23, no. 4, p. 375-391.

Lea, P.D., and Waythomas, C.F., 1990, Late-Pleistocene eolian sand sheets in Alaska: Quaternary Research, v. 34, p. 269-281.

Lee-Wong, Florence, Vallier, T.L., Hopkins, D.M., and Silberman, M.L., 1979, Preliminary report on the petrography and geochemistry of basalt from the Pribilof Islands and vicinity, southern Bering Sea: U.S. Geological Survey Open-File Report 79-1556, 51 p.

Levy, L.B., Kaufman, D.S., and Werner, Al, 2004, Holocene glacier fluctuations, Waskey Lake, northwestern Ahklun 
Mountains, southwestern Alaska: The Holocene, v. 14, no. 2, p. 185-193.

Mankinen, E.A., and Dalrymple, G.B., 1979, Revised geomagnetic polarity time scale for the interval 0-5 m.y. B.P.: Journal of Geophysical Research, v. 84, no. B2, p. 615-626.

Manley, W.F., Kaufman, D.S., and Briner, J.P., 2001, Pleistocene glacial history of the southern Ahklun Mountains, southwestern Alaska; soil-development, morphometric, and radiocarbon constraints: Quaternary Science Reviews, v. 20 , p. $353-370$.

Mertie, J.B., Jr., 1938, The Nushagak District, Alaska: U.S. Geological Survey Bulletin 903, 96 p., 2 plates in pocket.

Miller, M.L., Bradshaw, J.Y., Kimbrough, D.L., Stern, T.W., and Bundtzen, T.K., 1991, Isotopic evidence for early Proterozoic age of the Idono complex, west-central Alaska: Journal of Geology, v. 99, p. 209-223.

Miller, M.L, and Bundtzen, T.K., 1994, Generalized geologic map of the Iditarod quadrangle, Alaska, showing potassium-argon, major-oxide, trace-element, fossil, paleocurrent, and archaeological sample localities: U.S. Geological Survey Miscellaneous Field Studies Map MF-2219A, scale 1:250,000, $48 \mathrm{p}$.

Moll-Stalcup, Elizabeth, Wooden, J.L., Bradshaw, Jack, and Aleinikoff, John, 1996, Elemental and isotopic evidence for $2.1 \mathrm{Ga}$ arc magmatism in the Kilbuck terrane, southwestern Alaska, in Moore, T.E., and Dumoulin, J.A., eds., Geologic studies in Alaska by the U.S. Geological Survey, 1994: U.S. Geological Survey Bulletin 2152, p. 111-130.

Muller, E.H., 1952, The glacial geology of the Naknek district, the Bristol Bay region, Alaska: Champaign, University of Illinois, Ph.D. dissertation, 98 p.

Murphy, J.M., 1987, Early Cretaceous cessation of terrane accretion, northern Eek Mountains, southwestern Alaska, in Hamilton, T.D., and Galloway, J.P., eds., Geologic studies in Alaska by the U.S. Geological Survey during 1986: U.S. Geological Survey Circular 998, p. 83-85.

Murphy, J.M., 1989, Geology, sedimentary petrology, and tectonic synthesis of Early Cretaceous submarine fan deposits, northern Eek Mountains, southwest Alaska: Fairbanks, Alaska, University of Alaska, M.S. thesis, 118 p.

Orth, D.J., 1967, Dictionary of Alaska place names: U.S. Geological Survey Professional Paper 567, 1084 p., 12 plates.

Patton, W.W., Jr., and Csejtey, Bela, Jr., 1979, Geologic map of St. Lawrence Island, Alaska: U.S. Geological Survey Miscellaneous Geologic Investigations Series Map I-1203, scale 1:250,000.

Patton, W.W., Jr., Lanphere, M.A., Miller, T.P., and Scott, R.A., 1976, Age and tectonic significance of volcanic rocks on St. Matthew Island, Bering Sea, Alaska: U.S. Geological Survey Journal of Research, v. 4, no. 1, p. 67-73.

Patton, W.W., Jr., Miller, T.P., Berg, H.C., Gryc, George, Hoare, J.M., and Ovenshine, A.T., 1975, Reconnaissance geologic map of St. Matthew Island, Bering Sea, Alaska: U.S. Geological Survey Miscellaneous Field Studies Map MF-642, scale 1:125,000.

Patton, W.W., Jr., Wilson, F.H., and Labay, K.A., in press, Reconnaissance geologic map of the lower Yukon River region, Alaska: U.S. Geological Survey Scientific Investigations Map 3015, scale 1:500,000.

Patton, W.W., Jr., Wilson, F.H., Labay, K.A., and Shew, Nora, 2009, Reconnaissance geologic map and digital data for the Yukon-Koyukuk basin, Alaska: U.S. Geological Survey Scientific Investigations Map 2909, scale 1:500,000.

Robinson, M.S., and Decker, John, 1986, Preliminary age dates and analytical data for selected igneous rocks from the Sleetmute, Russian Mission, Taylor Mountains, and Bethel quadrangles, southwestern Alaska: Alaska Division of Geological and Geophysical Surveys Public Data-file 86-99, 7 p.

Roden, M., Frey, F.A., and Francis, D.M., 1980, REE and Sr isotopic geochemistry of pyroxenite and granulite xenoliths, Nunivak Island, Alaska [abs.]: Geological Society of America Abstracts with Programs, v. 12, no. 7, p. 511.

Saltus, R.W., and Milicevic, B., 2004, Preliminary grid data and maps for an aeromagnetic survey of the Taylor Mountains quadrangle and a portion of the Bethel quadrangle, Alaska: U.S. Geological Survey Open-File Report 2004-1293. (Available at http://pubs.usgs.gov/of/2004/1293/.)

Silberman, M.L., and Hopkins, D.M., 1976, Potassium argon ages of basement rocks from St. George Island, Alaska: U.S. Geological Survey Open-File Report 76-733, 11 p.

Simpson, G.L., Vallier, T.L., Pearl, J.E., and Lee-Wong, Florence, 1979, Potassium-argon ages and geochemistry of basalt dredged near Saint George Island, southern Bering Sea, in Johnson, K.M., and Williams, J.R., eds., The United States Geological Survey in Alaska-Accomplishments during 1978: U.S. Geological Survey Circular 804-B, p. B134-B135.

Spurr, J.E., 1900, A reconnaissance in southwestern Alaska: U.S. Geological Survey 20th Annual Report, pt. 7, p. 31-264.

Steiger, R.H., and Jager, E., 1977, Subcommission on geochronology - Convention on the use of decay constants in geo- and cosmochronology: Earth and Planetary Science Letters, v. 36, p. 359-362.

Turner, D.L., Forbes, R.B., Aleinikoff, J.N., Hedge, C.E., and MacDougall, Ian, 1983, Geochronology of the Kilbuck terrane of southwestern Alaska [abs.]: Geological Society of America Abstracts with Programs 1983, v. 15, no. 5, p. 407.

Turner, D.L., Forbes, R.B., Aleinikoff, J.N., MacDougall, Ian, and Hedge, C.E., 2009, Geologic and geochronologic studies of the Early Proterozoic Kanektok metamorphic complex of southwestern Alaska, with preface by Wilson, F.H., Layer, P.W., and Hults, C.P.: U.S. Geological Survey Open-File Report 2009-1248, 45p.

U.S. Geological Survey, 2006, Aeromagnetic survey of the Taylor Mountains area in southwest Alaska, A website for the distribution of data: U.S. Geological Survey Data Series 224 (Available at http://pubs.usgs.gov/ ds/2006/224/.)

Wahrhaftig, Clyde, 1965, Physiographic divisions of Alaska: U.S. Geological Survey Professional Paper 482, 52 p., 6 plates, scale 1:2,500,000. 
Walker, R.G., and Mutti, Emiliano, 1973, Turbidite facies and facies associations, in Turbidites and deep water sedimentation; Short course lecture notes: Society of Economic Paleontologists and Mineralogists, Pacific Section, Anaheim, California, p. 119-157.

Wallace, W.K., Hanks, C.L., and Rogers, J.F., 1989, The southern Kahiltna terrane; implications for the tectonic evolution of southwestern Alaska: Geological Society of America Bulletin, v. 101, p. 1,389-1,407.

Wilson, F.H., 1977, Some plutonic rocks of southwestern Alaska, a data compilation: U.S. Geological Survey OpenFile Report 77-501, 4 plates, 7 p.

Wilson, F.H., and Coonrad, W.L., 2005, The Togiak-Tikchik Complex of southwest Alaska, a replacement for the Gemuk Group; stratigraphic nomenclature that has outlived its time: U.S. Geological Survey Scientific Investigations Report 2005-5019, 12 p. (Available at http://pubs.usgs. gov/sir/2005/5019/.)

Wilson, F.H., Dover, J.H., Bradley, D.C., Weber, F.R., Bundtzen, T.K., and Haeussler, P.J., 1998, Geologic map of central (interior) Alaska: U.S. Geological Survey Open-File Report 98-133, 3 sheets, scale 1:500,000, 63 p. pamphlet, 13-p. appendix.

Wilson, F.H., Hudson, T.L., Grybeck, D., Stoeser, D.B., Preller, C.C., Bickerstaff, D., Labay, K., and Miller, M.L., 2003, Preliminary geologic map of the northeast Dillingham quadrangle (D-1, D-2, C-1, and C-2), Alaska: U.S. Geological Survey Open-File Report 03-105, 1 plate, 13 p., scale 1:100,000. (Available at http://geopubs.wr.usgs.gov/ open-file/of03-105/.)

Wilson, F.H., Labay, K.A., Shew, Nora, Hults, C.K., 2006a, Digital data for the reconnaissance geologic map of the lower Yukon River region, Alaska (geologic map by Patton, W.W., Jr., Wilson, F.H., and Labay, K.A.)-Pre- liminary integrated geologic map databases for the United States: U.S. Geological Survey Open-File Report 20061292. (Available at http://pubs.usgs.gov/of/2006/1292/.)

Wilson, F.H., Labay, K.A., Shew, Nora, and Mohadjer, Solmaz, 2005, Digital data for the reconnaissance geologic map of the Yukon-Koyukuk basin, Alaska (geologic map by Patton, W.W., Jr., Wilson, F.H., Labay, K.A., and Shew, Nora)_Preliminary integrated geologic map databases for the United States: U.S. Geological Survey Open-File Report 2005-1341. (Available at http://pubs.usgs.gov/ of/2005/1341/.)

Wilson, F.H., Mohadjer, Solmaz, Labay, K.A., Shew, Nora, 2006b, Digital data for the reconnaissance bedrock geologic map for the Northern Alaska Peninsula area, southwest Alaska (bedrock geologic map by Wilson, F.H., Blodgett, R.B., Blomé, C.D., Mohadjer, Solmaz, Preller, C.C., Klimasauskas, E.P., Gamble, B.M., and Coonrad, W.L.) - Preliminary integrated geologic map databases for the United States: U.S. Geological Survey Open-File Report 2006-1303. (Available at http://pubs.usgs.gov/ of $/ 2006 / 1303 /$.)

Wilson, F.H., and Smith, J.G., 1976, Map showing potassiumargon ages from the Goodnews quadrangle, Alaska: U.S. Geological Survey Open-File Report 76-437, scale $1: 250,000$.

Wilson, F.H., Smith, J.G., and Shew, Nora, 1985, Review of radiometric data from the Yukon Crystalline Terrane, Alaska and Yukon Territory: Canadian Journal of Earth Sciences, v. 22, no. 4, p. 525-537.

Wittbrodt, P.R., Stone, D.B., Turner, D.L., 1989, Paleomagnetism and geochronology of St. Matthew Island, Bering Sea: Canadian Journal of Earth Sciences, v. 26, no. 10, p. 2,116-2,129. 
Table 1. Radiometric ages, Kuskokwim Bay region, southwest Alaska.


biotite; CL, chlorite; HO, hornblende; IC, isochron; MI, mica; MU, muscovite; PL, plagioclase; RI, riebeckite; SE, sericite; SP, sphene; WR, whole-rock; ZI, zircon]

\begin{tabular}{|c|c|c|c|c|c|c|c|c|c|c|}
\hline Sample & Map unit & Quadrangle & $\begin{array}{l}\text { Latitude } \\
\text { (N.) }\end{array}$ & $\begin{array}{l}\text { Longitude } \\
\text { (W.) }\end{array}$ & Rock type & Method & $\begin{array}{c}\text { Material } \\
\text { Dated }\end{array}$ & $\begin{array}{l}\text { Age } \\
\text { (Ma) }\end{array}$ & $\begin{array}{l}\text { Error } \\
\text { (Ma) }\end{array}$ & Reference and notes \\
\hline A125 & Qcs & Cape Mendenhall & 59.983 & 166.367 & Basalt & $\mathrm{K} / \mathrm{Ar}$ & $\mathrm{AN}$ & 0.03 & 0.02 & $\begin{array}{l}\text { Cox and Dalrymple, 1967; Hoare and others, } \\
\text { 1968; Mankinen and Dalrymple, } 1979\end{array}$ \\
\hline A102 & Qcs & Nunivak Island & 60.000 & 166.333 & Basalt & $\mathrm{K} / \mathrm{Ar}$ & WR & .06 & .02 & $\begin{array}{l}\text { Cox and Dalrymple, 1967; Hoare and others, } \\
\text { 1968; Mankinen and Dalrymple, } 1979\end{array}$ \\
\hline A126 & Qcs & Nunivak Island & 60.017 & 166.183 & Basalt & $\mathrm{K} / \mathrm{Ar}$ & $\mathrm{AN}$ & .09 & .02 & $\begin{array}{l}\text { Cox and Dalrymple, 1967; Hoare and others, } \\
1968\end{array}$ \\
\hline A96 & Qcs & Nunivak Island & 60.017 & 166.2 & Basalt & $\mathrm{K} / \mathrm{Ar}$ & WR & .11 & .03 & $\begin{array}{l}\text { Cox and Dalrymple, 1967; Hoare and others, } \\
\text { 1968; Mankinen and Dalrymple, } 1979\end{array}$ \\
\hline A114 & Qcs & Cape Mendenhall & 59.95 & 166.167 & Basalt & $\mathrm{K} / \mathrm{Ar}$ & AN & .14 & .02 & $\begin{array}{l}\text { Cox and Dalrymple, 1967; Hoare and others, } \\
\text { 1968; Mankinen and Dalrymple, } 1979\end{array}$ \\
\hline A71 & Qcs & Cape Mendenhall & 59.978 & 165.657 & Basalt & $\mathrm{K} / \mathrm{Ar}$ & WR & .28 & .06 & $\begin{array}{l}\text { Cox and Dalrymple, 1967; Hoare and others, } \\
\text { 1968; Mankinen and Dalrymple, } 1979\end{array}$ \\
\hline A91 & Qvb & Nunivak Island & 60.033 & 166.083 & Basalt & $\mathrm{K} / \mathrm{Ar}$ & WR & .23 & .09 & $\begin{array}{l}\text { Cox and Dalrymple, 1967; Hoare and others, } \\
\text { 1968; Mankinen and Dalrymple, } 1979\end{array}$ \\
\hline A86 & Qvb & Nunivak Island & 60.017 & 166.067 & Basalt & $\mathrm{K} / \mathrm{Ar}$ & WR & .29 & .05 & $\begin{array}{l}\text { Cox and Dalrymple, 1967; Hoare and others, } \\
\text { 1968; Mankinen and Dalrymple, } 1979\end{array}$ \\
\hline A69 & Qvb & Nunivak Island & 60.053 & 165.682 & Basalt & $\mathrm{K} / \mathrm{Ar}$ & WR & .30 & .07 & $\begin{array}{l}\text { Cox and Dalrymple, 1967; Hoare and others, } \\
\text { 1968; Mankinen and Dalrymple, } 1979\end{array}$ \\
\hline A74 & Qvb & Cape Mendenhall & 59.933 & 165.562 & Basalt & $\mathrm{K} / \mathrm{Ar}$ & WR & .34 & .12 & $\begin{array}{l}\text { Cox and Dalrymple, 1967; Hoare and others, } \\
1968\end{array}$ \\
\hline A 88 & Qvb & Nunivak Island & 60.033 & 166.083 & Basalt & $\mathrm{K} / \mathrm{Ar}$ & WR & .35 & .05 & $\begin{array}{l}\text { Cox and Dalrymple, 1967; Hoare and others, } \\
\text { 1968; Mankinen and Dalrymple, } 1979\end{array}$ \\
\hline A78 & Qvb & Cape Mendenhall & 59.8667 & 165.85 & Basalt & $\mathrm{K} / \mathrm{Ar}$ & WR & .36 & .09 & $\begin{array}{l}\text { Cox and Dalrymple, 1967; Hoare and others, } \\
\text { 1968; Mankinen and Dalrymple, } 1979\end{array}$ \\
\hline 86ASb 9a & Qvb & Bethel & 60.355 & 159.863 & Basalt & $\mathrm{K} / \mathrm{Ar}$ & WR & .418 & .016 & Box and others, 1993 \\
\hline A70 & Qvb & Nunivak Island & 60.017 & 165.633 & Basalt & $\mathrm{K} / \mathrm{Ar}$ & WR & .50 & .06 & $\begin{array}{l}\text { Cox and Dalrymple, 1967; Hoare and others, } \\
\text { 1968; Mankinen and Dalrymple, } 1979\end{array}$ \\
\hline A59A & Qvb & Nunivak Island & 60.223 & 165.693 & Basalt & $\mathrm{K} / \mathrm{Ar}$ & WR & .63 & .09 & $\begin{array}{l}\text { Cox and Dalrymple, 1967; Hoare and others, } \\
\text { 1968; Mankinen and Dalrymple, } 1979\end{array}$ \\
\hline A108 & Qvb & Nunivak Island & 60 & 166.233 & Basalt & $\mathrm{K} / \mathrm{Ar}$ & WR & .67 & .07 & $\begin{array}{l}\text { Cox and Dalrymple, 1967; Hoare and others, } \\
\text { 1968; Mankinen and Dalrymple, } 1979\end{array}$ \\
\hline A97 & Qvb & Nunivak Island & 60.017 & 166.267 & Basalt & $\mathrm{K} / \mathrm{Ar}$ & WR & .69 & .09 & $\begin{array}{l}\text { Cox and Dalrymple, 1967; Hoare and others, } \\
\text { 1968; Mankinen and Dalrymple, } 1979\end{array}$ \\
\hline A101 & Qvb & Nunivak Island & 60.017 & 166.317 & Basalt & $\mathrm{K} / \mathrm{Ar}$ & WR & .74 & .09 & $\begin{array}{l}\text { Cox and Dalrymple, 1967; Hoare and others, } \\
\text { 1968; Mankinen and Dalrymple, } 1979\end{array}$ \\
\hline
\end{tabular}


Table 1. Radiometric ages, Kuskokwim Bay region, southwest Alaska—continued.

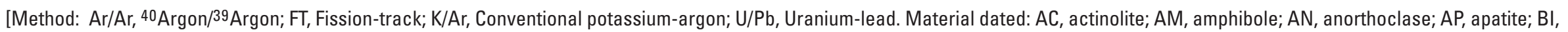
biotite; CL, chlorite; HO, hornblende; IC, isochron; MI, mica; MU, muscovite; PL, plagioclase; RI, riebeckite; SE, sericite; SP, sphene; WR, whole-rock; ZI, zircon]

\begin{tabular}{|c|c|c|c|c|c|c|c|c|c|c|}
\hline Sample & Map unit & Quadrangle & $\begin{array}{l}\text { Latitude } \\
\text { (N.) }\end{array}$ & $\begin{array}{l}\text { Longitude } \\
\text { (W.) }\end{array}$ & Rock type & Method & $\begin{array}{l}\text { Material } \\
\text { Dated }\end{array}$ & $\begin{array}{l}\text { Age } \\
\text { (Ma) }\end{array}$ & $\begin{array}{l}\text { Error } \\
\text { (Ma) }\end{array}$ & Reference and notes \\
\hline A61 & Qvb & Nunivak Island & 60.21 & 165.682 & Basalt & $\mathrm{K} / \mathrm{Ar}$ & WR & .75 & .75 & $\begin{array}{l}\text { Cox and Dalrymple, 1967; Hoare and others, } \\
\text { 1968; Mankinen and Dalrymple, } 1979\end{array}$ \\
\hline 74AHr77 & Qvb & Goodnews Bay & 59.297 & 159.97 & Basalt & $\mathrm{K} / \mathrm{Ar}$ & WR & .758 & .2 & Hoare and Coonrad, 1978; 1980; Box, 1985a \\
\hline A46 & Qvbm & Nunivak Island & 60.367 & 166.1 & Basalt & $\mathrm{K} / \mathrm{Ar}$ & WR & .81 & .10 & $\begin{array}{l}\text { Cox and Dalrymple, 1967; Hoare and others, } \\
\text { 1968; Mankinen and Dalrymple, } 1979\end{array}$ \\
\hline A 48 & Qvbm & Nunivak Island & 60.348 & 166.085 & Basalt & $\mathrm{K} / \mathrm{Ar}$ & WR & .86 & .08 & $\begin{array}{l}\text { Cox and Dalrymple, 1967; Hoare and others, } \\
\text { 1968; Mankinen and Dalrymple, } 1979\end{array}$ \\
\hline A 45 & Qvbm & Nunivak Island & 60.422 & 166.132 & Basalt & $\mathrm{K} / \mathrm{Ar}$ & WR & .87 & .07 & $\begin{array}{l}\text { Hoare and others, 1968; Mankinen and } \\
\text { Dalrymple, } 1979\end{array}$ \\
\hline A 35 & Qvbm & Nunivak Island & 60.365 & 166.3317 & Basalt & $\mathrm{K} / \mathrm{Ar}$ & WR & .93 & .07 & $\begin{array}{l}\text { Cox and Dalrymple, 1967; Hoare and others, } \\
\text { 1968; Mankinen and Dalrymple, } 1979 . \text { Mean of } \\
2 \text { analyses. }\end{array}$ \\
\hline A41 & Qvbm & Nunivak Island & 60.387 & 166.242 & Basalt & $\mathrm{K} / \mathrm{Ar}$ & WR & .95 & .08 & $\begin{array}{l}\text { Cox and Dalrymple, 1967; Hoare and others, } \\
1968 \text {; Mankinen and Dalrymple, 1979. Mean of } \\
2 \text { analyses. }\end{array}$ \\
\hline A23 & Qvbm & Nunivak Island & 60.327 & 166.703 & Basalt & $\mathrm{K} / \mathrm{Ar}$ & WR & 1.55 & .15 & $\begin{array}{l}\text { Hoare and others, } 1968 \text { (recalc.). Mean of } 2 \\
\text { analyses. }\end{array}$ \\
\hline A57 & Qvbm & Nunivak Island & 60.267 & 165.685 & Basalt & $\mathrm{K} / \mathrm{Ar}$ & WR & 1.58 & .09 & $\begin{array}{l}\text { Cox and Dalrymple, 1967; Hoare and others, } \\
\text { 1968; Mankinen and Dalrymple, } 1979\end{array}$ \\
\hline A51 & Qvbm & Nunivak Island & 60.323 & 166 & Basalt & $\mathrm{K} / \mathrm{Ar}$ & WR & 1.69 & .09 & $\begin{array}{l}\text { Cox and Dalrymple, 1967; Hoare and others, } \\
1968 \text {; Mankinen and Dalrymple, } 1979 . \text { Mean of } \\
2 \text { analyses. }\end{array}$ \\
\hline $\mathrm{P} 21$ & Qpd & Pribilof Islands & 56.596 & 169.514 & Basalt & $\mathrm{K} / \mathrm{Ar}$ & WR & 1.63 & .06 & $\begin{array}{l}\text { Cox and others, 1966; Mankinen and } \\
\text { Dalrymple, } 1979\end{array}$ \\
\hline P52 & QTv & Pribilof Islands & 57.131 & 170.291 & Basalt & $\mathrm{K} / \mathrm{Ar}$ & WR & $<0.10$ & -- & Cox and others, 1966 \\
\hline P35 & QTv & Pribilof Islands & 57.195 & 170.405 & Basalt & $\mathrm{K} / \mathrm{Ar}$ & WR & .124 & .058 & $\begin{array}{l}\text { Average age of splits listed below. Mankinen } \\
\text { and Dalrymple, 1979; Lee-Wong and others, } \\
1979\end{array}$ \\
\hline P35 & QTv & Pribilof Islands & 57.195 & 170.405 & Basalt & $\mathrm{K} / \mathrm{Ar}$ & WR & $\begin{array}{l}.096 \\
.065 \\
.200\end{array}$ & $\begin{array}{l}.10 \\
.10 \\
.10\end{array}$ & Cox and others, 1966; Hoare and others, 1968 \\
\hline P38 & QTV & Pribilof Islands & 57.184 & 170.416 & Basalt & $\mathrm{K} / \mathrm{Ar}$ & WR & .33 & .04 & $\begin{array}{l}\text { Cox and others, 1966; Cox and Dalrymple, } \\
\text { 1967; Mankinen and Dalrymple, } 1979\end{array}$ \\
\hline P38 & QTv & Pribilof Islands & 57.184 & 170.416 & Basalt & $\mathrm{K} / \mathrm{Ar}$ & WR & $\begin{array}{l}.33 \\
.36\end{array}$ & $\begin{array}{l}.10 \\
.10\end{array}$ & Cox and others, 1966 \\
\hline
\end{tabular}


Table 1. Radiometric ages, Kuskokwim Bay region, southwest Alaska—continued.

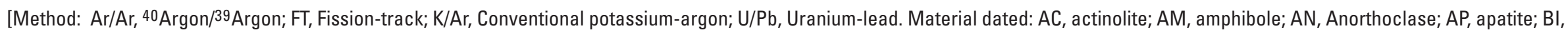
biotite; CL, chlorite; HO, hornblende; IC, isochron; MI, mica; MU, muscovite; PL, plagioclase; RI, riebeckite; SE, sericite; SP, sphene; WR, whole-rock; ZI, zircon]

\begin{tabular}{|c|c|c|c|c|c|c|c|c|c|c|}
\hline Sample & Map unit & Quadrangle & $\begin{array}{l}\text { Latitude } \\
\text { (N.) }\end{array}$ & $\begin{array}{l}\text { Longitude } \\
\text { (W.) }\end{array}$ & Rock type & Method & $\begin{array}{l}\text { Material } \\
\text { Dated }\end{array}$ & $\begin{array}{l}\text { Age } \\
\text { (Ma) }\end{array}$ & $\begin{array}{l}\text { Error } \\
\text { (Ma) }\end{array}$ & Reference and notes \\
\hline P11 & QTV & Pribilof Islands & 56.594 & 169.474 & Basalt & $\mathrm{K} / \mathrm{Ar}$ & WR & 1.82 & .07 & Cox and others, 1966 \\
\hline P11 & QTV & Pribilof Islands & 56.594 & 169.474 & Basalt & $\mathrm{K} / \mathrm{Ar}$ & WR & 1.85 & .06 & $\begin{array}{l}\text { Cox and Dalrymple, 1967; Hoare and others, } \\
\text { 1968; Mankinen and Dalrymple, 1979; Cox and } \\
\text { others, } 1966\end{array}$ \\
\hline P20 & QTV & Pribilof Islands & 56.609 & 169.527 & Basalt & $\mathrm{K} / \mathrm{Ar}$ & WR & 1.85 & .07 & Cox and others, 1966 \\
\hline P5 & QTV & Pribilof Islands & 56.580 & 169.573 & Basalt & $\mathrm{K} / \mathrm{Ar}$ & WR & $\begin{array}{l}1.88 \\
1.94\end{array}$ & $\begin{array}{l}.09 \\
.08\end{array}$ & $\begin{array}{l}\text { Cox and others, 1966, Mankinen and } \\
\text { Dalrymple, } 1979\end{array}$ \\
\hline P19 & QTV & Pribilof Islands & 56.603 & 169.495 & Basalt & $\mathrm{K} / \mathrm{Ar}$ & WR & 1.97 & .06 & Cox and others, 1966 \\
\hline P3 & QTv & Pribilof Islands & 56.604 & 169.566 & Basalt & $\mathrm{K} / \mathrm{Ar}$ & WR & $\begin{array}{l}1.97 \\
2.04\end{array}$ & $\begin{array}{l}.08 \\
.08\end{array}$ & $\begin{array}{l}\text { Cox and others, 1966, Cox and Dalrymple, } \\
\text { 1967; Mankinen and Dalrymple, } 1979\end{array}$ \\
\hline P2 & QTV & Pribilof Islands & 56.605 & 169.556 & Basalt & $\mathrm{K} / \mathrm{Ar}$ & WR & 2.00 & .10 & $\begin{array}{l}\text { Cox and others, 1966, Cox and Dalrymple, } \\
\text { 1967; Mankinen and Dalrymple, } 1979\end{array}$ \\
\hline $\mathrm{P} 12$ & QTv & Pribilof Islands & 56.598 & 169.472 & Basalt & $\mathrm{K} / \mathrm{Ar}$ & WR & 2.12 & .08 & $\begin{array}{l}\text { Cox and others, 1966, Cox and Dalrymple, } \\
\text { 1967; Mankinen and Dalrymple, } 1979\end{array}$ \\
\hline $\mathrm{P} 13$ & QTV & Pribilof Islands & 56.597 & 169.471 & Basalt & $\mathrm{K} / \mathrm{Ar}$ & WR & 2.15 & .08 & $\begin{array}{l}\text { Cox and others, 1966, Cox and Dalrymple, } \\
\text { 1967; Mankinen and Dalrymple, } 1979\end{array}$ \\
\hline P67 & QTV & Pribilof Islands & 56.583 & 169.584 & Basalt & $\mathrm{K} / \mathrm{Ar}$ & WR & 2.16 & .06 & Cox and others, 1966 \\
\hline $\mathrm{P} 10$ & QTv & Pribilof Islands & 56.594 & 169.474 & Basalt & $\mathrm{K} / \mathrm{Ar}$ & WR & 2.19 & .06 & Cox and others, 1966 \\
\hline P15 & QTV & Pribilof Islands & 56.600 & 169.486 & Basalt & $\mathrm{K} / \mathrm{Ar}$ & WR & 2.19 & .08 & Cox and others, 1966 \\
\hline P66 & QTV & Pribilof Islands & 56.578 & 169.504 & Basalt & $\mathrm{K} / \mathrm{Ar}$ & WR & 2.25 & .10 & Cox and others, 1966 \\
\hline A50 & QTab & Nunivak Island & 60.317 & 166.017 & Basalt & $\mathrm{K} / \mathrm{Ar}$ & WR & .88 & .07 & $\begin{array}{l}\text { Cox and Dalrymple, 1967; Hoare and others, } \\
\text { 1968; Mankinen and Dalrymple, } 1979\end{array}$ \\
\hline A19 & Ttb & Nunivak Island & 60.2 & 166.917 & Basalt & $\mathrm{K} / \mathrm{Ar}$ & WR & 3.24 & .10 & $\begin{array}{l}\text { Cox and Dalrymple, 1967; Hoare and others, } \\
\text { 1968; Mankinen and Dalrymple, } 1979\end{array}$ \\
\hline A6 & Ttb & Nunivak Island & 60.233 & 167.295 & Basalt & $\mathrm{K} / \mathrm{Ar}$ & WR & 3.36 & .10 & $\begin{array}{l}\text { Hoare and others, 1968; Mankinen and } \\
\text { Dalrymple, } 1979\end{array}$ \\
\hline A7 & Ttb & Nunivak Island & 60.233 & 167.215 & Basalt & $\mathrm{K} / \mathrm{Ar}$ & WR & 3.40 & .12 & $\begin{array}{l}\text { Cox and Dalrymple, 1967; Hoare and others, } \\
\text { 1968; Mankinen and Dalrymple, } 1979\end{array}$ \\
\hline A3 & Ttb & Nunivak Island & 60.208 & 167.435 & Basalt & $\mathrm{K} / \mathrm{Ar}$ & WR & 4.15 & .12 & $\begin{array}{l}\text { Cox and Dalrymple, 1967; Hoare and others, } \\
\text { 1968; Mankinen and Dalrymple, } 1979\end{array}$ \\
\hline $\mathrm{A} 2$ & Ttb & Nunivak Island & 60.213 & 167.458 & Basalt & $\mathrm{K} / \mathrm{Ar}$ & WR & 4.25 & .12 & $\begin{array}{l}\text { Cox and Dalrymple, 1967; Hoare and others, } \\
\text { 1968; Mankinen and Dalrymple, } 1979\end{array}$ \\
\hline
\end{tabular}


Table 1. Radiometric ages, Kuskokwim Bay region, southwest Alaska—continued.

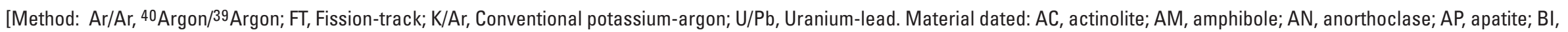
biotite; $\mathrm{CL}$, chlorite; HO, hornblende; IC, isochron; MI, mica; MU, muscovite; PL, plagioclase; RI, riebeckite; SE, sericite; SP, sphene; WR, whole-rock; ZI, zircon]

\begin{tabular}{|c|c|c|c|c|c|c|c|c|c|c|}
\hline Sample & Map unit & Quadrangle & $\begin{array}{l}\text { Latitude } \\
\text { (N.) }\end{array}$ & $\begin{array}{l}\text { Longitude } \\
\text { (W.) }\end{array}$ & Rock type & Method & $\begin{array}{l}\text { Material } \\
\text { Dated }\end{array}$ & $\begin{array}{l}\text { Age } \\
\text { (Ma) }\end{array}$ & $\begin{array}{l}\text { Error } \\
\text { (Ma) }\end{array}$ & Reference and notes \\
\hline A12 & Ttb & Nunivak Island & 60.225 & 166.95 & Basalt & $\mathrm{K} / \mathrm{Ar}$ & WR & 4.96 & .14 & $\begin{array}{l}\text { Cox and Dalrymple, 1967; Hoare and others, } \\
\text { 1968; Mankinen and Dalrymple, } 1979\end{array}$ \\
\hline A8 & Ttb & Nunivak Island & 60.22 & 167.063 & Basalt & $\mathrm{K} / \mathrm{Ar}$ & WR & 4.97 & .15 & $\begin{array}{l}\text { Cox and Dalrymple, 1967; Hoare and others, } \\
\text { 1968; Mankinen and Dalrymple, } 1979\end{array}$ \\
\hline A11 & Ttb & Nunivak Island & 60.225 & 166.95 & Basalt & $\mathrm{K} / \mathrm{Ar}$ & WR & 5.01 & .15 & $\begin{array}{l}\text { Cox and Dalrymple, 1967; Hoare and others, } \\
\text { 1968; Mankinen and Dalrymple, } 1979\end{array}$ \\
\hline A17 & Ttb & Nunivak Island & 60.212 & 166.945 & Basalt & $\mathrm{K} / \mathrm{Ar}$ & WR & 5.01 & .15 & $\begin{array}{l}\text { Cox and Dalrymple, 1967; Hoare and others, } \\
\text { 1968; Mankinen and Dalrymple, } 1979\end{array}$ \\
\hline A15 & Talb & Nunivak Island & 60.22 & 166.94 & Basalt & $\mathrm{K} / \mathrm{Ar}$ & WR & 5.19 & .15 & $\begin{array}{l}\text { Dalrymple and others, 1967; Cox and } \\
\text { Dalrymple, 1967; Hoare and others, } 1968\end{array}$ \\
\hline A1 & Talb & Nunivak Island & 60.213 & 167.458 & Basalt & $\mathrm{K} / \mathrm{Ar}$ & WR & 6.28 & .18 & $\begin{array}{l}\text { Dalrymple and others, 1967; Cox and } \\
\text { Dalrymple, 1967; Hoare and others, } 1968\end{array}$ \\
\hline $74 \mathrm{AHr} 26$ & Tfi & Hagemeister Is. & 58.95 & 160.01 & Rhyodacite & $\mathrm{K} / \mathrm{Ar}$ & $\mathrm{BI}$ & 13.00 & .50 & $\begin{array}{l}\text { Wilson, 1977; Hoare and Coonrad, 1978; Box, } \\
\text { 1985a }\end{array}$ \\
\hline G199 & Tad & Pribilof Islands & 56.575 & 169.5 & Quartz diorite & $\mathrm{K} / \mathrm{Ar}$ & $\begin{array}{l}\text { SE } \\
\text { PL }\end{array}$ & $\begin{array}{l}49.5 \\
55.0\end{array}$ & $\begin{array}{l}2.0 \\
2.2\end{array}$ & $\begin{array}{l}\text { Silberman and Hopkins, 1976; Hopkins and } \\
\text { Silberman, } 1978\end{array}$ \\
\hline ISOCHRON & Tad & Pribilof Islands & 56.575 & 169.5 & Quartz diorite & $\mathrm{K} / \mathrm{Ar}$ & $\mathrm{IC}$ & 51.7 & 1.9 & $\begin{array}{l}\text { Silberman and Hopkins, 1976; Hopkins and } \\
\text { Silberman, } 1978\end{array}$ \\
\hline G200 & Tad & Pribilof Islands & 56.575 & 169.5 & Quartz diorite & $\mathrm{K} / \mathrm{Ar}$ & $\begin{array}{l}\text { AN } \\
\text { CL }\end{array}$ & $\begin{array}{l}52.7 \\
57.2\end{array}$ & $\begin{array}{l}2.1 \\
2.3\end{array}$ & $\begin{array}{l}\text { Silberman and Hopkins, 1976; Hopkins and } \\
\text { Silberman, } 1978\end{array}$ \\
\hline $87 \mathrm{ACz} 75 \mathrm{M}$ & Tnr & Bethel & 60.766 & 160.23 & Rhyolite & $\mathrm{Ar} / \mathrm{Ar}$ & RI & 54.7 & 1.6 & Box and others, 1993 \\
\hline 82JD 450B & $\mathrm{TKr}$ & Bethel & 60.583 & 160.272 & Rhyolite & $\mathrm{K} / \mathrm{Ar}$ & $\begin{array}{l}\text { WR } \\
\mathrm{BI}\end{array}$ & $\begin{array}{l}59.3 \\
62.5\end{array}$ & $\begin{array}{l}1.8 \\
1.9\end{array}$ & $\begin{array}{l}\text { Robinson and Decker, 1986; Box and others, } \\
1993\end{array}$ \\
\hline 88AMl 12 & $\mathrm{TKa}$ & Bethel & 60.576 & 160.427 & Andesite & $\mathrm{Ar} / \mathrm{Ar}$ & $\mathrm{PL}$ & 59.5 & 12.3 & Box and others, 1993 \\
\hline GD5-1771 & $\mathrm{TKg}$ & Goodnews Bay & 59.853 & 160.813 & Dacite & $\mathrm{K} / \mathrm{Ar}$ & $\mathrm{HO}$ & 68.7 & 3.0 & Hoare and Coonrad, 1978 \\
\hline B78-1133G & $\mathrm{TKg}$ & Hagemeister Is. & 58.847 & 160.232 & Diorite & $\mathrm{K} / \mathrm{Ar}$ & $\mathrm{BI}$ & 75.0 & 2.9 & Box, $1985 \mathrm{a}$ \\
\hline GC4-1300 & TKgr & Goodnews Bay & 59.618 & 160.142 & Granite porphyry & $\mathrm{K} / \mathrm{Ar}$ & $\mathrm{HO}$ & 60.7 & 1.8 & $\begin{array}{l}\text { Wilson and Smith, 1976; Wilson, 1977; Hoare } \\
\text { and Coonrad, } 1978\end{array}$ \\
\hline 87ATf 62 & TKgr & Bethel & 60.521 & 159.164 & Granite & $\mathrm{Ar} / \mathrm{Ar}$ & $\mathrm{BI}$ & 60.8 & 1.8 & Box and others, 1993 \\
\hline 74B57 & TKgr & Goodnews Bay & 59.627 & 159 & Granite & $\mathrm{K} / \mathrm{Ar}$ & $\begin{array}{c}\mathrm{HO} \\
\mathrm{BI}\end{array}$ & $\begin{array}{l}63.4 \\
69.6\end{array}$ & $\begin{array}{l}3.0 \\
2.1\end{array}$ & $\begin{array}{l}\text { Wilson and Smith, 1976; Wilson, 1977; Hoare } \\
\text { and Coonrad, } 1978\end{array}$ \\
\hline 74AHr51 & TKgs & Nushagak Bay & 58.897 & 159.48 & Monzonite & $\mathrm{K} / \mathrm{Ar}$ & BI & 71.9 & 2.0 & $\begin{array}{l}\text { Wilson, 1977; Hoare and Coonrad, 1978; Box, } \\
\text { 1985a }\end{array}$ \\
\hline
\end{tabular}


Table 1. Radiometric ages, Kuskokwim Bay region, southwest Alaska—continued.

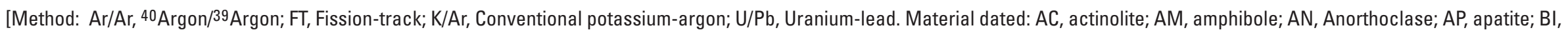
biotite; $\mathrm{CL}$, chlorite; HO, hornblende; IC, isochron; MI, mica; MU, muscovite; PL, plagioclase; RI, riebeckite; SE, sericite; SP, sphene; WR, whole-rock; ZI, zircon]

\begin{tabular}{|c|c|c|c|c|c|c|c|c|c|c|}
\hline Sample & Map unit & Quadrangle & $\begin{array}{l}\text { Latitude } \\
\text { (N.) }\end{array}$ & $\begin{array}{l}\text { Longitude } \\
\text { (W.) }\end{array}$ & Rock type & Method & $\begin{array}{l}\text { Material } \\
\text { Dated }\end{array}$ & $\begin{array}{l}\text { Age } \\
\text { (Ma) }\end{array}$ & $\begin{array}{l}\text { Error } \\
\text { (Ma) }\end{array}$ & Reference and notes \\
\hline 74AHr118 & TKqm & Goodnews Bay & 59.66 & 159.672 & Quartz monzonite & $\mathrm{K} / \mathrm{Ar}$ & $\begin{array}{c}\mathrm{BI} \\
\mathrm{HO}\end{array}$ & $\begin{array}{l}63.7 \\
69.5\end{array}$ & $\begin{array}{l}2.0 \\
3.0\end{array}$ & $\begin{array}{l}\text { Wilson and Smith, 1976; Wilson, 1977; Hoare } \\
\text { and Coonrad, } 1978\end{array}$ \\
\hline 87ATf 51 & TKqm & Bethel & 60.275 & 159.633 & Granite & $\mathrm{Ar} / \mathrm{Ar}$ & BI & 69.8 & 2.1 & Box and others, 1993 \\
\hline $87 \mathrm{AJm} 36 \mathrm{a}$ & TKqm & Bethel & 60.152 & 159.936 & Granodiorite & $\mathrm{Ar} / \mathrm{Ar}$ & BI & 70.3 & 2.1 & Box and others, 1993 \\
\hline 73AHr1 & TKqm & Goodnews Bay & 59.918 & 159.915 & Granodiorite & $\mathrm{K} / \mathrm{Ar}$ & BI & 71.1 & 2.1 & $\begin{array}{l}\text { Wilson and Smith, 1976; Wilson, 1977; Hoare } \\
\text { and Coonrad, 1978; Frost and others, } 1988\end{array}$ \\
\hline 71AMm45 & TKgd & St. Matthew & 60.4 & 172.698 & Granodiorite & $\mathrm{K} / \mathrm{Ar}$ & $\mathrm{HO}$ & 62.3 & 2.0 & $\begin{array}{l}\text { Patton and others, 1975; Silberman and } \\
\text { Hopkins, 1976; Wittbrodt and others, } 1989\end{array}$ \\
\hline 87ATf 72 & TKgd & Bethel & 60.644 & 159.661 & Granite & $\mathrm{Ar} / \mathrm{Ar}$ & $\mathrm{BI}$ & 62.2 & 1.9 & Box and others, 1993 \\
\hline GD1-3154 & TKgd & Goodnews Bay & 59.843 & 159.182 & Granodiorite & $\mathrm{K} / \mathrm{Ar}$ & $\begin{array}{c}\mathrm{BI} \\
\mathrm{AM}\end{array}$ & $\begin{array}{l}62.5 \\
65.2\end{array}$ & $\begin{array}{l}1.8 \\
1.9\end{array}$ & $\begin{array}{l}\text { Wilson and Smith, 1976; Wilson, 1977; Hoare } \\
\text { and Coonrad, } 1978\end{array}$ \\
\hline GB1-3156 & TKgd & Goodnews Bay & 59.465 & 159.177 & Quartz diorite & $\mathrm{K} / \mathrm{Ar}$ & $\begin{array}{c}\mathrm{HO} \\
\mathrm{BI}\end{array}$ & $\begin{array}{l}63.4 \\
69.5\end{array}$ & $\begin{array}{l}1.8 \\
2.0\end{array}$ & $\begin{array}{l}\text { Wilson and Smith, 1976; Wilson, 1977; Hoare } \\
\text { and Coonrad, } 1978\end{array}$ \\
\hline 87ATf 56 & TKgd & Bethel & 60.468 & 159.409 & Granite & $\mathrm{Ar} / \mathrm{Ar}$ & $\mathrm{BI}$ & 64.3 & 1.9 & Box and others, 1993 \\
\hline GA5-1310 & TKgd & Goodnews Bay & 59.172 & 160.648 & Quartz diorite & $\mathrm{K} / \mathrm{Ar}$ & BI & 67.4 & 2.0 & $\begin{array}{l}\text { Wilson and Smith, 1976; Wilson, 1977; Hoare } \\
\text { and Coonrad, 1978; Box, 1985a }\end{array}$ \\
\hline GC1-1381 & TKgd & Goodnews Bay & 59.665 & 159.36 & $\begin{array}{l}\text { Tonalite - Quartz } \\
\text { diorite }\end{array}$ & $\mathrm{K} / \mathrm{Ar}$ & BI & 72.5 & 2.2 & $\begin{array}{l}\text { Wilson and Smith, 1976; Wilson, 1977; Hoare } \\
\text { and Coonrad, } 1978\end{array}$ \\
\hline $87 \mathrm{ACz} 61$ & TKqd & Bethel & 60.941 & 159.659 & Quartz diorite & $\mathrm{K} / \mathrm{Ar}$ & BI & 65.1 & 2.0 & Box and others, 1993 \\
\hline 87AJm 271b & TKqd & Bethel & 60.394 & 159.118 & Diorite & $\mathrm{Ar} / \mathrm{Ar}$ & $\mathrm{HO}$ & 68.0 & 2.0 & Box and others, 1993 \\
\hline GB7-1479a & TKqd & Goodnews Bay & 59.347 & 161.325 & Quartz diorite & $\mathrm{K} / \mathrm{Ar}$ & BI & 71.3 & 2.1 & $\begin{array}{l}\text { Wilson and Smith, 1976; Wilson, 1977; Hoare } \\
\text { and Coonrad, } 1978\end{array}$ \\
\hline $74 \mathrm{ACd} 14 \mathrm{~d}$ & $\begin{array}{l}\text { TKm; dike } \\
\text { in Ks }\end{array}$ & Nushagak Bay & 58.852 & 159.978 & Diabase & $\mathrm{K} / \mathrm{Ar}$ & BI & 64.6 & 2.0 & Hoare and Coonrad, 1978; Box, 1985a \\
\hline $12-106$ & $\mathrm{Kv}$ & St. Matthew & 60.335 & 172.433 & Basalt & $\mathrm{K} / \mathrm{Ar}$ & WR & 52.2 & 1.6 & Wittbrodt and others, 1989 \\
\hline $81 \mathrm{SB}-35 \mathrm{~b}$ & Kv & Hagemeister Is. & 58.777 & 160.787 & Andesite & $\mathrm{K} / \mathrm{Ar}$ & WR & 64.5 & 3.2 & Box, $1985 \mathrm{a}$ \\
\hline 8106301 & $\mathrm{Kv}$ & Hagemeister Is. & 58.8 & 160.75 & Basalt & $\mathrm{K} / \mathrm{Ar}$ & WR & 64.5 & 3.2 & Globerman, 1985 \\
\hline 71APa10 & $\mathrm{Kv}$ & St. Matthew & 60.562 & 172.942 & Basalt & $\mathrm{K} / \mathrm{Ar}$ & WR & 66.5 & 2.0 & $\begin{array}{l}\text { Patton and others, 1975, 1976; Silberman and } \\
\text { Hopkins, 1976; Wittbrodt and others, } 1989\end{array}$ \\
\hline $5-29$ & $\mathrm{Kv}$ & St. Matthew & 60.583 & 172.967 & Andesite & $\mathrm{K} / \mathrm{Ar}$ & WR & 68.0 & 2.3 & Wittbrodt and others, 1989 \\
\hline 8107126 & $\mathrm{Kv}$ & Hagemeister Is. & 58.78 & 160.757 & Andesite & $\mathrm{K} / \mathrm{Ar}$ & WR & 68.3 & .4 & Globerman, 1985; Box, 1985a \\
\hline 8107131 & $\mathrm{Kv}$ & Hagemeister Is. & 58.785 & 160.748 & Andesite & $\mathrm{K} / \mathrm{Ar}$ & WR & 68.7 & 3.7 & Globerman, 1985; Box, 1985a \\
\hline
\end{tabular}


Table 1. Radiometric ages, Kuskokwim Bay region, southwest Alaska—continued.

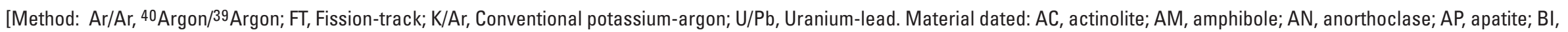
biotite; CL, chlorite; HO, hornblende; IC, isochron; MI, mica; MU, muscovite; PL, plagioclase; RI, riebeckite; SE, sericite; SP, sphene; WR, whole-rock; ZI, zircon]

\begin{tabular}{|c|c|c|c|c|c|c|c|c|c|c|}
\hline Sample & Map unit & Quadrangle & $\begin{array}{l}\text { Latitude } \\
\text { (N.) }\end{array}$ & $\begin{array}{l}\text { Longitude } \\
\text { (W.) }\end{array}$ & Rock type & Method & $\begin{array}{l}\text { Material } \\
\text { Dated }\end{array}$ & $\begin{array}{l}\text { Age } \\
\text { (Ma) }\end{array}$ & $\begin{array}{l}\text { Error } \\
\text { (Ma) }\end{array}$ & Reference and notes \\
\hline 82JD 435A & $\mathrm{Kv}$ & Bethel & 60.770 & 159.107 & Andesite & $\mathrm{K} / \mathrm{Ar}$ & $\begin{array}{l}\mathrm{PL} \\
\mathrm{WR}\end{array}$ & $\begin{array}{l}69.0 \\
71.4\end{array}$ & $\begin{array}{l}2.1 \\
2.1\end{array}$ & $\begin{array}{l}\text { Robinson and Decker, 1986; Box and others, } \\
1993\end{array}$ \\
\hline $1-2$ & $\mathrm{Kv}$ & St. Matthew & 60.57 & 172.997 & Andesite & $\mathrm{K} / \mathrm{Ar}$ & WR & 69.2 & 2.1 & Wittbrodt and others, 1989 \\
\hline 88ASb 99a & $\mathrm{Kv}$ & Bethel & 60.782 & 159.170 & Dacite & $\mathrm{Ar} / \mathrm{Ar}$ & BI & 69.5 & 2.1 & Box and others, 1993 \\
\hline $4-16$ & $\mathrm{Kv}$ & St. Matthew & 60.482 & 172.953 & Basalt & $\mathrm{K} / \mathrm{Ar}$ & WR & 73.0 & 2.2 & Wittbrodt and others, 1989 \\
\hline $5-33$ & $\mathrm{Kv}$ & St. Matthew & 60.583 & 172.963 & Andesite & $\mathrm{K} / \mathrm{Ar}$ & WR & 73.8 & 2.2 & Wittbrodt and others, 1989 \\
\hline 86ASb 1 & $\mathrm{Kv}$ & Bethel & 60.323 & 159.627 & Andesite & $\mathrm{Ar} / \mathrm{Ar}$ & WR & 74.3 & 2.2 & Box and others, 1993 \\
\hline $5-123$ & $\mathrm{Kv}$ & St. Matthew & 60.583 & 172.963 & Andesite & $\mathrm{K} / \mathrm{Ar}$ & WR & 76.0 & 2.3 & Wittbrodt and others, 1989 \\
\hline B78-1125G & $\begin{array}{l}\text { Kv?; Dike } \\
\text { in Ks }\end{array}$ & Hagemeister Is. & 58.853 & 160.213 & Andesite & $\mathrm{K} / \mathrm{Ar}$ & $\mathrm{HO}$ & 76.6 & 4.5 & Box, $1985 \mathrm{a}$ \\
\hline $5-27$ & $\mathrm{Kv}$ & St. Matthew & 60.583 & 172.963 & Andesite & $\mathrm{K} / \mathrm{Ar}$ & WR & 76.5 & 2.3 & Wittbrodt and others, 1989 \\
\hline $12-105$ & $\mathrm{Kv}$ & St. Matthew & 60.335 & 172.433 & Basalt & $\mathrm{K} / \mathrm{Ar}$ & WR & 78.1 & 2.3 & Wittbrodt and others, 1989 \\
\hline $5-125$ & $\mathrm{Kv}$ & St. Matthew & 60.583 & 172.963 & Andesite & $\mathrm{K} / \mathrm{Ar}$ & WR & 78.7 & 2.4 & Wittbrodt and others, 1989 \\
\hline 71APa15 & $\mathrm{Kv}$ & St. Matthew & 60.583 & 172.975 & Basalt & $\mathrm{K} / \mathrm{Ar}$ & WR & 78.7 & 2.0 & $\begin{array}{l}\text { Patton and others, 1975, 1976; Silberman and } \\
\text { Hopkins, 1976; Wittbrodt and others, } 1989\end{array}$ \\
\hline $5-31$ & $\mathrm{Kv}$ & St. Matthew & 60.583 & 172.963 & Andesite & $\mathrm{K} / \mathrm{Ar}$ & WR & 79.2 & 2.4 & Wittbrodt and others, 1989 \\
\hline 71AMm50 & Kpd & St. Matthew & 60.6533 & 173.06 & Tuff & $\mathrm{K} / \mathrm{Ar}$ & $\begin{array}{c}\mathrm{BI} \\
\mathrm{HO}\end{array}$ & $\begin{array}{l}76.0 \\
76.3\end{array}$ & $\begin{array}{l}2.0 \\
2.0\end{array}$ & $\begin{array}{l}\text { Patton and others, 1975, 1976; Silberman and } \\
\text { Hopkins, 1976; Wittbrodt and others, } 1989\end{array}$ \\
\hline 87 ATf 30 & $\mathrm{Kg}$ & Bethel & 60.577 & 160.788 & Granodiorite & $\mathrm{K} / \mathrm{Ar}$ & $\mathrm{BI}$ & 115.0 & 3.5 & Box and others, 1993 \\
\hline 88ATF24d & $\mathrm{Kg}$ & Bethel & 60.158 & 159.822 & Granodiorite & $\mathrm{U} / \mathrm{Pb}$ & ZI & $\begin{array}{l}104- \\
129\end{array}$ & -- & Box and others, 1993, upper intercept \\
\hline HD6-2272a & Jum & Hagemeister Is. & 58.9112 & 161.772 & Amphibolite & $\mathrm{K} / \mathrm{Ar}$ & $\mathrm{AM}$ & 176.4 & 5.3 & Hoare and Coonrad, 1978; Box, 1985a \\
\hline HD6-1453e & Jum & Hagemeister Is. & 58.918 & 161.775 & Amphibolite & $\mathrm{K} / \mathrm{Ar}$ & $\mathrm{AM}$ & 186.9 & 5.6 & Hoare and Coonrad, 1978; Box, 1985a \\
\hline 74AHr112 & $\mathrm{Jgb}$ & Hagemeister Is. & 58.987 & 160.97 & Gabbro & $\mathrm{K} / \mathrm{Ar}$ & $\mathrm{HO}$ & 159.3 & 3.5 & $\begin{array}{l}\text { Wilson, 1977; Hoare and Coonrad, 1978; Box, } \\
\text { 1985a. Matogak, minimum age. }\end{array}$ \\
\hline GA7-1450 & $J g b$ & Goodnews Bay & 59.022 & 161.523 & Diorite & $\mathrm{K} / \mathrm{Ar}$ & AM & 162.4 & 4.9 & $\begin{array}{l}\text { Wilson and Smith, 1976; Wilson, 1977; Hoare } \\
\text { and Coonrad, 1978; Box, 1985a. Crater Hill }\end{array}$ \\
\hline B78-1171G & $J g b$ & Hagemeister Is. & 58.93 & 160.698 & Gabbro & $\mathrm{K} / \mathrm{Ar}$ & $\mathrm{HO}$ & 174. & 8. & Box, 1985a \\
\hline 74AHr111 & $\mathrm{Jgb}$ & Hagemeister Is. & 58.963 & 161.05 & Gabbro & $\mathrm{K} / \mathrm{Ar}$ & $\mathrm{HO}$ & 186.9 & 6.0 & $\begin{array}{l}\text { Wilson, 1977; Hoare and Coonrad, 1978; Box, } \\
\text { 1985a. Downdraft Mountain }\end{array}$ \\
\hline
\end{tabular}


Table 1. Radiometric ages, Kuskokwim Bay region, southwest Alaska—continued.

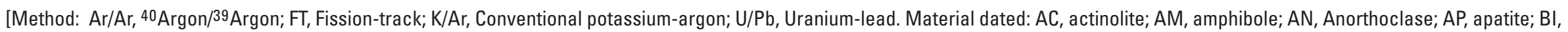
biotite; $\mathrm{CL}$, chlorite; HO, hornblende; IC, isochron; MI, mica; MU, muscovite; PL, plagioclase; RI, riebeckite; SE, sericite; SP, sphene; WR, whole-rock; ZI, zircon]

\begin{tabular}{|c|c|c|c|c|c|c|c|c|c|c|}
\hline Sample & Map unit & Quadrangle & $\begin{array}{l}\text { Latitude } \\
\text { (N.) }\end{array}$ & $\begin{array}{l}\text { Longitude } \\
\text { (W.) }\end{array}$ & Rock type & Method & $\begin{array}{l}\text { Material } \\
\text { Dated }\end{array}$ & $\begin{array}{l}\text { Age } \\
\text { (Ma) }\end{array}$ & $\begin{array}{l}\text { Error } \\
\text { (Ma) }\end{array}$ & Reference and notes \\
\hline 81SB116b & $\mathrm{Jgb} /$ Kod & Hagemeister Is. & 58.853 & 160.99 & Hornfels & $\mathrm{K} / \mathrm{Ar}$ & $\mathrm{AM}$ & 187. & 10. & $\begin{array}{l}\text { Box, 1985a Hornfels in Kud associated with } \\
\text { Jgb }\end{array}$ \\
\hline B78-1152G & Jlgd & Hagemeister Is. & 58.615 & 161.073 & Granodiorite & $\mathrm{K} / \mathrm{Ar}$ & $\begin{array}{l}\mathrm{BI} \text { or } \\
\mathrm{HO} ?\end{array}$ & 183. & 7. & $\begin{array}{l}\text { Box, } 1985 \mathrm{a} \text {; age suspect due to unusual } \mathrm{K}_{2} \mathrm{O} \\
\text { content of mineral dated; see text for map unit } \\
\text { Jlgd }\end{array}$ \\
\hline 89ASb 101 & MDv & Bethel & 60.178 & 160.128 & Dacite & FT & AP & 47.5 & 6.9 & Box and others, 1993 \\
\hline $81 \mathrm{SB} 107 \mathrm{~A}$ & $\mathrm{kPmb}$ & Hagemeister Is. & 58.843 & 161.025 & Phyllite & $\mathrm{K} / \mathrm{Ar}$ & MI & 150. & 8. & Box, 1985a,b \\
\hline $81 \mathrm{SB} 133 \mathrm{a}$ & kPmb & Hagemeister Is. & 58.752 & 161.307 & Schist & $\mathrm{K} / \mathrm{Ar}$ & MI & 155. & 8. & Box, 1985a,b \\
\hline $82 \mathrm{SB} 147$ & kPvs & Hagemeister Is. & 58.637 & 161.883 & Schist & $\mathrm{K} / \mathrm{Ar}$ & $\mathrm{HO}$ & 231.2 & 6.9 & Box, 1985a,b \\
\hline B78-1213 & Jgs & Bethel & 60.342 & 160.313 & Schist & $\mathrm{K} / \mathrm{Ar}$ & $\mathrm{AC}$ & 146.0 & 15.0 & Box and others, 1993 \\
\hline $88 \mathrm{ML} \mathrm{22b}$ & $\mathrm{Pk}$ & Bethel & 60.093 & 160.6 & Gneiss & FT & AP & 66.6 & 4.6 & Box and others, 1993 \\
\hline DT76-21 & $\mathrm{Pk}$ & Goodnews Bay & 59.92 & 161.932 & Hornblende diorite & $\mathrm{K} / \mathrm{Ar}$ & $\mathrm{HO}$ & 122.2 & 3.6 & Turner and others, 2009 \\
\hline DT76-57 & $\mathrm{ek}$ & Goodnews Bay & 59.955 & 160.898 & $\begin{array}{l}\text { Biotite-muscovite } \\
\text { gneiss }\end{array}$ & $\mathrm{K} / \mathrm{Ar}$ & $\begin{array}{c}\mathrm{MU} \\
\mathrm{BI}\end{array}$ & $\begin{array}{l}127.7 \\
131.9\end{array}$ & $\begin{array}{l}3.9 \\
3.9\end{array}$ & Turner and others, 2009 \\
\hline DT75-67 & $\mathrm{Pk}$ & Goodnews Bay & 59.55 & 161.44 & $\begin{array}{l}\text { Biotite-muscovite } \\
\text { granodiorite gneiss }\end{array}$ & $\mathrm{K} / \mathrm{Ar}$ & $\begin{array}{l}\mathrm{BI} \\
\mathrm{MU}\end{array}$ & $\begin{array}{l}128.0 \\
135.8\end{array}$ & $\begin{array}{l}3.7 \\
4.0\end{array}$ & Turner and others, 2009 \\
\hline DT76-58 & $\mathrm{Pk}$ & Goodnews Bay & 59.953 & 160.893 & Hornblende diorite & $\mathrm{K} / \mathrm{Ar}$ & $\mathrm{HO}$ & 128.7 & 3.8 & Turner and others, 2009; minimum age \\
\hline DT75-66 & $\mathrm{Pk}$ & Goodnews Bay & 59.562 & 161.432 & $\begin{array}{l}\text { Biotite-hornblende } \\
\text { granodiorite gneiss }\end{array}$ & $\mathrm{K} / \mathrm{Ar}$ & $\begin{array}{l}\mathrm{BI} \\
\mathrm{HO}\end{array}$ & $\begin{array}{l}128.9 \\
140.5\end{array}$ & $\begin{array}{l}3.8 \\
4.1\end{array}$ & Turner and others, 2009 \\
\hline DT76-41 & $\mathrm{Pk}$ & Goodnews Bay & 59.947 & 160.912 & $\begin{array}{l}\text { Biotite-hornblende } \\
\text { epidote schist }\end{array}$ & $\mathrm{K} / \mathrm{Ar}$ & $\begin{array}{c}\mathrm{HO} \\
\mathrm{BI}\end{array}$ & $\begin{array}{l}129.6 \\
158.8\end{array}$ & $\begin{array}{l}3.8 \\
4.7\end{array}$ & Turner and others, 2009 \\
\hline DT75-79 & $\mathrm{Pk}$ & Goodnews Bay & 59.543 & 161.593 & $\begin{array}{l}\text { Biotite-epidote } \\
\text { schist }\end{array}$ & $\mathrm{K} / \mathrm{Ar}$ & BI & 130.4 & 3.8 & Turner and others, 2009 \\
\hline DT76-22 & $\mathrm{Pk}$ & Goodnews Bay & 59.903 & 161.92 & Garnet amphibolite & $\mathrm{K} / \mathrm{Ar}$ & $\mathrm{HO}$ & 130.6 & 3.8 & Turner and others, 2009 \\
\hline DT76-31 & $\mathrm{Pk}$ & Goodnews Bay & 59.922 & 161.902 & $\begin{array}{l}\text { Biotite-muscovite } \\
\text { gneiss }\end{array}$ & $\mathrm{K} / \mathrm{Ar}$ & $\begin{array}{c}\text { MU } \\
\text { BI }\end{array}$ & $\begin{array}{l}130.6 \\
196.8\end{array}$ & $\begin{array}{l}3.8 \\
5.8\end{array}$ & Turner and others, 2009 \\
\hline DT76-52 & $\mathrm{Pk}$ & Goodnews Bay & 59.922 & 160.887 & $\begin{array}{l}\text { Quartz muscovite } \\
\text { gneiss }\end{array}$ & $\mathrm{K} / \mathrm{Ar}$ & MU & 130.6 & 3.9 & Turner and others, 2009 \\
\hline DT75-64 & $\mathrm{Pk}$ & Goodnews Bay & 59.572 & 161.442 & $\begin{array}{l}\text { Biotite-hornblende } \\
\text { granodiorite gneiss }\end{array}$ & $\mathrm{K} / \mathrm{Ar}$ & $\begin{array}{l}\text { BI } \\
\mathrm{HO}\end{array}$ & $\begin{array}{l}130.8 \\
141.7\end{array}$ & $\begin{array}{l}3.8 \\
4.1\end{array}$ & Turner and others, 2009 \\
\hline DT75-63 & $\mathrm{Pk}$ & Goodnews Bay & 59.577 & 161.45 & $\begin{array}{l}\text { Biotite granodio- } \\
\text { rite gneiss }\end{array}$ & $\mathrm{K} / \mathrm{Ar}$ & BI & 133.2 & 3.9 & Turner and others, 2009 \\
\hline
\end{tabular}


Table 1. Radiometric ages, Kuskokwim Bay region, southwest Alaska—continued.

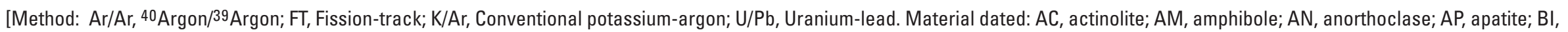
biotite; CL, chlorite; HO, hornblende; IC, isochron; MI, mica; MU, muscovite; PL, plagioclase; RI, riebeckite; SE, sericite; SP, sphene; WR, whole-rock; ZI, zircon]

\begin{tabular}{|c|c|c|c|c|c|c|c|c|c|c|}
\hline Sample & Map unit & Quadrangle & $\begin{array}{l}\text { Latitude } \\
\text { (N.) }\end{array}$ & $\begin{array}{l}\text { Longitude } \\
\text { (W.) }\end{array}$ & Rock type & Method & $\begin{array}{l}\text { Material } \\
\text { Dated }\end{array}$ & $\begin{array}{l}\text { Age } \\
\text { (Ma) }\end{array}$ & $\begin{array}{l}\text { Error } \\
\text { (Ma) }\end{array}$ & Reference and notes \\
\hline DT76-42 & $\mathrm{Pk}$ & Goodnews Bay & 59.947 & 160.913 & $\begin{array}{l}\text { Biotite-muscovite } \\
\text { granodiorite gneiss }\end{array}$ & $\mathrm{K} / \mathrm{Ar}$ & BI & 133.3 & 4.0 & Turner and others, 2009 \\
\hline $75 \mathrm{AFS}-18 \mathrm{ck}$ & $\mathrm{Pk}$ & Goodnews Bay & 59.62 & 161.2 & $\begin{array}{l}\text { Biotite-bearing } \\
\text { amphibolite }\end{array}$ & $\mathrm{K} / \mathrm{Ar}$ & $\mathrm{HO}$ & 133.7 & 3.9 & Turner and others, 2009 \\
\hline 75AFS-18ak & $\mathrm{Pk}$ & Goodnews Bay & 59.617 & 161.205 & $\begin{array}{l}\text { Biotite-muscovite } \\
\text { granodiorite gneiss }\end{array}$ & $\mathrm{K} / \mathrm{Ar}$ & $\begin{array}{c}\text { MU } \\
\text { BI }\end{array}$ & $\begin{array}{l}135.6 \\
143.7\end{array}$ & $\begin{array}{l}3.9 \\
4.2\end{array}$ & Turner and others, 2009 \\
\hline DT75-78 & $\mathrm{Pk}$ & Goodnews Bay & 59.54 & 161.588 & Greenschist & $\mathrm{K} / \mathrm{Ar}$ & $\mathrm{AC}$ & 137.1 & 4.0 & Turner and others, 2009 \\
\hline $75 \mathrm{AFS}-12 \mathrm{k}$ & $\mathrm{Pk}$ & Goodnews Bay & 59.577 & 161.235 & Garnet amphibolite & $\mathrm{K} / \mathrm{Ar}$ & $\begin{array}{c}\mathrm{BI} \\
\mathrm{HO}\end{array}$ & $\begin{array}{l}136.5 \\
163.2\end{array}$ & $\begin{array}{l}3.9 \\
4.8\end{array}$ & Turner and others, 2009 \\
\hline 75AFS-35ak & $\mathrm{Pk}$ & Goodnews Bay & 59.582 & 161.397 & $\begin{array}{l}\text { Biotite-hornblende } \\
\text { granodiorite }\end{array}$ & $\mathrm{K} / \mathrm{Ar}$ & $\begin{array}{c}\mathrm{BI} \\
\mathrm{HO}\end{array}$ & $\begin{array}{l}138.8 \\
235.5\end{array}$ & $\begin{array}{l}4.1 \\
6.9\end{array}$ & Turner and others, 2009 \\
\hline DT76-34 & $\mathrm{Pk}$ & Goodnews Bay & 59.925 & 161.898 & Biotite gneiss & $\mathrm{K} / \mathrm{Ar}$ & BI & 140.8 & 4.1 & Turner and others, 2009 \\
\hline DT76-72 & $\mathrm{Pk}$ & Bethel & 60.127 & 160.567 & $\begin{array}{l}\text { Biotite-horn- } \\
\text { blende-epidote- } \\
\text { plagioclase rock }\end{array}$ & $\mathrm{K} / \mathrm{Ar}$ & $\begin{array}{c}\mathrm{BI} \\
\mathrm{HO}\end{array}$ & $\begin{array}{l}143.6 \\
153.4\end{array}$ & $\begin{array}{l}4.2 \\
4.5\end{array}$ & Turner and others, 2009 ; biotite is minimum age \\
\hline DT75-68 & $\mathrm{Pk}$ & Goodnews Bay & 59.547 & 161.437 & $\begin{array}{l}\text { Biotite garnet } \\
\text { amphibole }\end{array}$ & $\mathrm{K} / \mathrm{Ar}$ & $\mathrm{HO}$ & 144.2 & 4.2 & Turner and others, 2009 \\
\hline 75AFS-3k & $\mathrm{Pk}$ & Goodnews Bay & 59.607 & 161.225 & $\begin{array}{l}\text { Epidote amphibo- } \\
\text { lite }\end{array}$ & $\mathrm{K} / \mathrm{Ar}$ & $\begin{array}{l}\text { BI } \\
\mathrm{HO}\end{array}$ & $\begin{array}{l}146.3 \\
170.5\end{array}$ & $\begin{array}{l}4.3 \\
4.9\end{array}$ & Turner and others, 2009; impure biotite \\
\hline DT75-81 & $\mathrm{Pk}$ & Goodnews Bay & 59.543 & 161.593 & $\begin{array}{l}\text { Biotite-bearing } \\
\text { greenschist }\end{array}$ & $\mathrm{K} / \mathrm{Ar}$ & $\mathrm{AC}$ & 146.6 & 4.3 & Turner and others, 2009 \\
\hline DT75-73 & $\mathrm{Pk}$ & Goodnews Bay & 59.563 & 161.382 & $\begin{array}{l}\text { Biotite-muscovite } \\
\text { gneiss }\end{array}$ & $\mathrm{K} / \mathrm{Ar}$ & MU & 153.2 & 4.5 & Turner and others, 2009 \\
\hline DT75-73 & $\mathrm{Pk}$ & Goodnews Bay & 59.563 & 161.382 & $\begin{array}{l}\text { Biotite-muscovite } \\
\text { gneiss }\end{array}$ & $\mathrm{K} / \mathrm{Ar}$ & BI & 196.1 & 5.7 & Turner and others, 2009 \\
\hline DT76-36 & $\mathrm{Pk}$ & Goodnews Bay & 59.93 & 161.895 & $\begin{array}{l}\text { Biotite-muscovite- } \\
\text { quartz schist }\end{array}$ & $\mathrm{K} / \mathrm{Ar}$ & $\begin{array}{c}\text { MU } \\
\text { BI }\end{array}$ & $\begin{array}{l}156.5 \\
395.6\end{array}$ & $\begin{array}{c}4.6 \\
12\end{array}$ & Turner and others, 2009; impure biotite \\
\hline DT76-74 & $\mathrm{Pk}$ & Bethel & 60.127 & 160.567 & $\begin{array}{l}\text { Biotite-horn- } \\
\text { blende-epidote } \\
\text { rock }\end{array}$ & $\mathrm{K} / \mathrm{Ar}$ & $\begin{array}{c}\mathrm{BI} \\
\mathrm{HO}\end{array}$ & $\begin{array}{l}162.1 \\
328.7\end{array}$ & $\begin{array}{l}4.7 \\
9.7\end{array}$ & Turner and others, 2009 \\
\hline 75AFS-1k & $\mathrm{Pk}$ & Goodnews Bay & 59.6117 & 161.228 & $\begin{array}{l}\text { Biotite-muscovite } \\
\text { gneiss }\end{array}$ & $\mathrm{K} / \mathrm{Ar}$ & BI & 169.7 & 4.9 & Turner and others, 2009 \\
\hline DT75-60 & $\mathrm{Pk}$ & Goodnews Bay & 59.543 & 161.462 & Garnet amphibolite & $\mathrm{K} / \mathrm{Ar}$ & $\mathrm{HO}$ & 169.7 & 5.0 & Turner and others, 2009 \\
\hline
\end{tabular}


Table 1. Radiometric ages, Kuskokwim Bay region, southwest Alaska—continued.

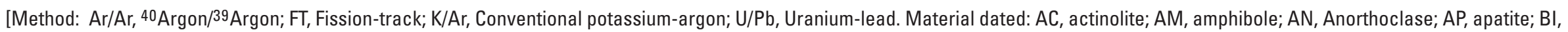
biotite; $\mathrm{CL}$, chlorite; HO, hornblende; IC, isochron; MI, mica; MU, muscovite; PL, plagioclase; RI, riebeckite; SE, sericite; SP, sphene; WR, whole-rock; ZI, zircon]

\begin{tabular}{|c|c|c|c|c|c|c|c|c|c|c|}
\hline Sample & Map unit & Quadrangle & $\begin{array}{l}\text { Latitude } \\
\text { (N.) }\end{array}$ & $\begin{array}{l}\text { Longitude } \\
\text { (W.) }\end{array}$ & Rock type & Method & $\begin{array}{l}\text { Material } \\
\text { Dated }\end{array}$ & $\begin{array}{l}\text { Age } \\
\text { (Ma) }\end{array}$ & $\begin{array}{l}\text { Error } \\
\text { (Ma) }\end{array}$ & Reference and notes \\
\hline 75AFS-22ak & $\mathrm{Pk}$ & Goodnews Bay & 65.45 & 161.205 & $\begin{array}{l}\text { Biotite-hornblende } \\
\text { diorite gneiss }\end{array}$ & $\mathrm{K} / \mathrm{Ar}$ & $\begin{array}{l}\mathrm{BI} \\
\mathrm{HO}\end{array}$ & $\begin{array}{l}170.3 \\
197.3 \\
245.3\end{array}$ & $\begin{array}{l}4.9 \\
5.8 \\
7.2\end{array}$ & $\begin{array}{l}\text { Turner and others, } 2009 \text {; replicate analyses, } \\
183.9 \pm 19.3 \text { average age on biotite; biotite } \mathrm{K}_{2} \mathrm{O} \\
\text { very low }\end{array}$ \\
\hline 75AFS-28ak & $\mathrm{ek}$ & Goodnews Bay & 59.57 & 161.442 & $\begin{array}{l}\text { Biotite-hornblende } \\
\text { diorite gneiss }\end{array}$ & $\mathrm{K} / \mathrm{Ar}$ & $\mathrm{HO}$ & 186.6 & 5.5 & Turner and others, 2009 \\
\hline DT76-56 & $\mathrm{Pk}$ & Goodnews Bay & 59.97 & 160.847 & $\begin{array}{l}\text { Biotite-muscovite- } \\
\text { hornblende schist }\end{array}$ & $\mathrm{K} / \mathrm{Ar}$ & $\begin{array}{c}\text { MU } \\
\text { BI }\end{array}$ & $\begin{array}{l}186.9 \\
351.3\end{array}$ & $\begin{array}{r}5.5 \\
10.3\end{array}$ & Turner and others, 2009 \\
\hline DT76-46 & $\mathrm{Pk}$ & Goodnews Bay & 59.94 & 160.923 & $\begin{array}{l}\text { Biotite-hornblende } \\
\text { muscovite schist }\end{array}$ & $\mathrm{K} / \mathrm{Ar}$ & $\begin{array}{c}\mathrm{HO} \\
\mathrm{BI}\end{array}$ & $\begin{array}{l}192.2 \\
223.7\end{array}$ & $\begin{array}{l}5.6 \\
6.6\end{array}$ & Turner and others, 2009 \\
\hline 75AFS-23ak & $\mathrm{ek}$ & Goodnews Bay & 59.65 & 161.207 & $\begin{array}{l}\text { Biotite-hornblende } \\
\text { diorite gneiss }\end{array}$ & $\mathrm{K} / \mathrm{Ar}$ & BI & 199.7 & 5.8 & Turner and others, 2009 \\
\hline DT76-61 & $\mathrm{Pk}$ & Goodnews Bay & 59.945 & 160.882 & $\begin{array}{l}\text { Porphyoblastic } \\
\text { amphibolite }\end{array}$ & $\mathrm{K} / \mathrm{Ar}$ & $\mathrm{HO}$ & 201.0 & 5.9 & Turner and others, 2009 \\
\hline DT75-83 & $\mathrm{Pk}$ & Goodnews Bay & 59.65 & 161.21 & $\begin{array}{l}\text { Biotite-hornblende } \\
\text { diorite gneiss }\end{array}$ & $\mathrm{K} / \mathrm{Ar}$ & BI & 212.6 & 6.2 & $\begin{array}{l}\text { Turner and others, } 2009 \text {; analytical data is same } \\
\text { as reported for biotite of DT75-82, is suspicious } \\
\text { and possibly in error. }\end{array}$ \\
\hline DT75-82 & $\mathrm{ek}$ & Goodnews Bay & 59.65 & 161.212 & $\begin{array}{l}\text { Biotite-hornblende } \\
\text { diorite gneiss }\end{array}$ & $\mathrm{K} / \mathrm{Ar}$ & $\begin{array}{l}\mathrm{BI} \\
\mathrm{HO}\end{array}$ & $\begin{array}{l}212.6 \\
215.8 \\
217.8\end{array}$ & $\begin{array}{l}6.2 \\
6.3 \\
6.4\end{array}$ & $\begin{array}{l}\text { Turner and others, } 2009 \text {; replicate analyses, } \\
214.2 \pm 6.3 \text { average age reported for biotite. }\end{array}$ \\
\hline DT76-66 & $\mathrm{Pk}$ & Goodnews Bay & 59.902 & 160.902 & Unknown & $\mathrm{K} / \mathrm{Ar}$ & BI & 246.9 & 7.2 & Turner and others, 2009; rock type not reported \\
\hline DT75-74 & $\mathrm{ek}$ & Goodnews Bay & 59.567 & 161.385 & Garnet amphibole & $\mathrm{K} / \mathrm{Ar}$ & $\mathrm{HO}$ & 247.1 & 7.2 & Turner and others, 2009 \\
\hline DT75-62 & $\mathrm{ek}$ & Goodnews Bay & 59.578 & 161.455 & Garnet amphibolite & $\mathrm{K} / \mathrm{Ar}$ & $\mathrm{HO}$ & 247.8 & 7.2 & Turner and others, 2009 \\
\hline DT76-71 & $\mathrm{Pk}$ & Bethel & 60.095 & 160.628 & $\begin{array}{l}\text { Biotite-hornblende } \\
\text { gneiss }\end{array}$ & $\mathrm{K} / \mathrm{Ar}$ & $\mathrm{HO}$ & 266 & 7.8 & Turner and others, 2009; minimum age \\
\hline DT76-39 & $\mathrm{ek}$ & Goodnews Bay & 59.913 & 160.897 & $\begin{array}{l}\text { Granodiorite } \\
\text { gneiss }\end{array}$ & $\mathrm{K} / \mathrm{Ar}$ & $\mathrm{BI}$ & 292.4 & 8.6 & Turner and others, 2009 \\
\hline DT76-62 & $\mathrm{ek}$ & Goodnews Bay & 59.905 & 160.903 & Amphibolite & $\mathrm{K} / \mathrm{Ar}$ & $\mathrm{HO}$ & 406.4 & 18 & Turner and others, 2009 \\
\hline $50 \mathrm{AHr} 747 \mathrm{a}$ & $\mathrm{ek}$ & Goodnews Bay & 59.725 & 161.108 & Quartz diorite & $\mathrm{K} / \mathrm{Ar}$ & $\begin{array}{c}\mathrm{BI} \\
\mathrm{HO}\end{array}$ & $\begin{array}{l}439.2 \\
450.2 \\
540.1 \\
544.2\end{array}$ & $\begin{array}{l}13 \\
13 \\
15.9 \\
16.1\end{array}$ & $\begin{array}{l}\text { Turner and others, } 2009 \text {; replicate analyses, } \\
444.7 \pm 13 \text { Ma average age for biotite, } 542.1 \pm 16 \\
\text { Ma average age for hornblende }\end{array}$ \\
\hline DT75-69 & $\mathrm{ek}$ & Goodnews Bay & 59.563 & 161.38 & Garnet amphibole & $\begin{array}{l}\text { Ar/Ar, total } \\
\text { fusion }\end{array}$ & $\mathrm{HO}$ & 478 & 4.2 & Turner and others, 2009; disturbed spectrum \\
\hline
\end{tabular}


Table 1. Radiometric ages, Kuskokwim Bay region, southwest Alaska—continued.

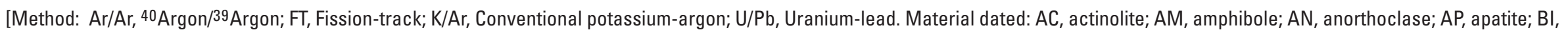
biotite; CL, chlorite; HO, hornblende; IC, isochron; MI, mica; MU, muscovite; PL, plagioclase; RI, riebeckite; SE, sericite; SP, sphene; WR, whole-rock; ZI, zircon]

\begin{tabular}{|c|c|c|c|c|c|c|c|c|c|c|}
\hline Sample & Map unit & Quadrangle & $\begin{array}{l}\text { Latitude } \\
\text { (N.) }\end{array}$ & $\begin{array}{l}\text { Longitude } \\
\text { (W.) }\end{array}$ & Rock type & Method & $\begin{array}{c}\text { Material } \\
\text { Dated }\end{array}$ & $\begin{array}{l}\text { Age } \\
\text { (Ma) }\end{array}$ & $\begin{array}{l}\text { Error } \\
\text { (Ma) }\end{array}$ & Reference and notes \\
\hline DT75-70 & $\mathrm{Ek}$ & Goodnews Bay & 59.558 & 161.38 & $\begin{array}{l}\text { Biotite quartz } \\
\text { monzonite gneiss }\end{array}$ & $\begin{array}{l}\mathrm{Ar} / \mathrm{Ar} \text {, total } \\
\text { fusion }\end{array}$ & BI & 487 & 4.3 & $\begin{array}{l}\text { Turner and others, 2009; spectra suggests partial } \\
\text { argon loss }\end{array}$ \\
\hline DT75-70 & $\mathrm{Pk}$ & Goodnews Bay & 59.558 & 161.38 & $\begin{array}{l}\text { Biotite quartz } \\
\text { monzonite gneiss }\end{array}$ & $\mathrm{K} / \mathrm{Ar}$ & BI & 498.0 & 14.7 & Turner and others, 2009 \\
\hline DT76-76 & $\mathrm{Pk}$ & Goodnews Bay & 59.857 & 160.903 & Garnet amphibolite & $\mathrm{K} / \mathrm{Ar}$ & $\mathrm{HO}$ & 637 & 19 & Turner and others, 2009 \\
\hline DT76-70 & $\mathrm{ek}$ & Bethel & 60.093 & 160.6 & Biotite amphibolite & $\mathrm{K} / \mathrm{Ar}$ & $\begin{array}{c}\mathrm{BI} \\
\mathrm{HO}\end{array}$ & $\begin{array}{l}685 \\
915\end{array}$ & $\begin{array}{l}20 \\
27\end{array}$ & Turner and others, 2009 \\
\hline DT76-70 & $\mathrm{ek}$ & Bethel & 60.093 & 160.6 & Biotite amphibolite & $\begin{array}{l}\text { Ar/Ar, } \\
\text { Plateau }\end{array}$ & $\mathrm{HO}$ & 936 & 36 & $\begin{array}{l}\text { Paul Layer, written commun., 2006; rerun of } \\
\text { conventional K/Ar age, shows disturbed spectra, } \\
\text { indicating conventional age is suspect }\end{array}$ \\
\hline DT76-70r & $\mathrm{ek}$ & Bethel & 60.093 & 160.6 & Biotite amphibolite & $\begin{array}{l}\text { Ar/Ar, } \\
\text { Plateau }\end{array}$ & $\mathrm{HO}$ & 974 & 10.7 & $\begin{array}{l}\text { Paul Layer, written commun., 2006; Replicate } \\
\text { rerun of conventional K/Ar age, shows disturbed } \\
\text { spectra, indicating conventional age is suspect }\end{array}$ \\
\hline DT75-76 & ek & Goodnews Bay & 59.547 & 161.403 & Garnet amphibole & $\mathrm{K} / \mathrm{Ar}$ & $\mathrm{HO}$ & $\begin{array}{l}1037 \\
1063\end{array}$ & $\begin{array}{l}31 \\
32\end{array}$ & $\begin{array}{l}\text { Turner and others, } 2009 \text {; replicate analyses, } \\
1049 \pm 32 \text { average age }\end{array}$ \\
\hline DT75-76 & $\mathrm{Pk}$ & Goodnews Bay & 59.547 & 161.403 & Garnet amphibole & $\begin{array}{c}\text { Ar/Ar, Total } \\
\text { Fusion }\end{array}$ & $\mathrm{HO}$ & 1124 & 8 & $\begin{array}{l}\text { Turner and others, } 2009 \text {; replicate conventional } \\
\mathrm{K} / \text { Ar analyses, } 1049 \pm 32 \text { average age; } 40 / 39 \\
\text { plateau age } 1.16 \mathrm{Ga} \text {. }\end{array}$ \\
\hline $50 \mathrm{AHr} 49$ & $\mathrm{Pk}$ & Goodnews Bay & 59.55 & 161.333 & Garnet amphibole & $\mathrm{K} / \mathrm{Ar}$ & $\mathrm{HO}$ & 1088. & 32. & $\begin{array}{l}\text { R.B. Forbes, D.L. Turner, and J.M. Hoare, writ- } \\
\text { ten commun., } 1973\end{array}$ \\
\hline DT76-69a & $\mathrm{Pk}$ & Goodnews Bay & 59.9 & 160.897 & Garnet amphibolite & $\mathrm{K} / \mathrm{Ar}$ & $\mathrm{HO}$ & 1770 & 53 & Turner and others, 2009 \\
\hline DT76-69a & $\mathrm{Pk}$ & Goodnews Bay & 59.9 & 160.897 & Garnet amphibolite & $\begin{array}{l}\mathrm{Ar} / \mathrm{Ar} \\
\text { Plateau }\end{array}$ & $\mathrm{HO}$ & 1778 & 89 & $\begin{array}{l}\text { Paul Layer, written commun., 2006; rerun of } \\
\text { conventional } \mathrm{K} / \mathrm{Ar} \text { age }\end{array}$ \\
\hline DT75-86 & $\mathrm{ek}$ & Goodnews Bay & 59.648 & 161.205 & $\begin{array}{l}\text { Quartz monzonite } \\
\text { orthogneiss }\end{array}$ & $\mathrm{U} / \mathrm{Pb}$ & $\mathrm{SP}$ & 1770 & & $\begin{array}{l}\text { Turner and others, 2009. Interpreted as age of } \\
\text { metamorphism. }\end{array}$ \\
\hline DT75-86 & $\mathrm{ek}$ & Goodnews Bay & 59.648 & 161.205 & $\begin{array}{l}\text { Quartz monzonite } \\
\text { orthogneiss }\end{array}$ & $\mathrm{U} / \mathrm{Pb}$ & ZI & 2050 & 30 & $\begin{array}{l}\text { Turner and others, 2009. Interpreted as an } \\
\text { emplacement age. }\end{array}$ \\
\hline $88 \mathrm{ML} 22 \mathrm{~b}$ & $\mathrm{ek}$ & Bethel & 60.093 & 160.600 & Granitic gneiss & $\mathrm{U} / \mathrm{Pb}$ & ZI & 2040 & 74 & Box and others, 1993, upper intercept \\
\hline 87ASB125b & $\mathrm{Pk}$ & Bethel & 60.300 & 160.334 & $\begin{array}{l}\text { Trondhjemite } \\
\text { gneiss }\end{array}$ & $\mathrm{U} / \mathrm{Pb}$ & ZI & 2070 & 16 & Box and others, 1993, upper intercept \\
\hline DT75-61 & ek & Goodnews Bay & 59.543 & 161.458 & $\begin{array}{l}\text { Retrograded } \\
\text { pyroxene granulite }\end{array}$ & $\mathrm{K} / \mathrm{Ar}$ & BI & $\begin{array}{l}2231 \\
2312\end{array}$ & $\begin{array}{l}67 \\
70\end{array}$ & $\begin{array}{l}\text { Turner and others, } 2009 \text {; replicate analyses, } \\
2271 \pm 70 \text { average age }\end{array}$ \\
\hline
\end{tabular}


Table 1. Radiometric ages, Kuskokwim Bay region, southwest Alaska—continued.

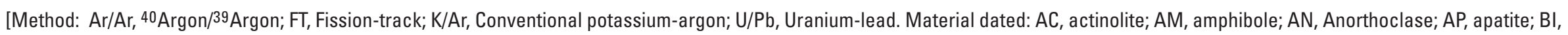
biotite; $\mathrm{CL}$, chlorite; HO, hornblende; IC, isochron; MI, mica; MU, muscovite; PL, plagioclase; RI, riebeckite; SE, sericite; SP, sphene; WR, whole-rock; ZI, zircon]

\begin{tabular}{|c|c|c|c|c|c|c|c|c|c|c|}
\hline Sample & Map unit & Quadrangle & $\begin{array}{l}\text { Latitude } \\
\text { (N.) }\end{array}$ & $\begin{array}{l}\text { Longitude } \\
\text { (W.) }\end{array}$ & Rock type & Method & $\begin{array}{l}\text { Material } \\
\text { Dated }\end{array}$ & $\begin{array}{l}\text { Age } \\
\text { (Ma) }\end{array}$ & $\begin{array}{l}\text { Error } \\
\text { (Ma) }\end{array}$ & Reference and notes \\
\hline DT75-71 & $\mathrm{Pk}$ & Goodnews Bay & 59.555 & 161.372 & Pyroxene granulite & $\mathrm{K} / \mathrm{Ar}$ & BI & $\begin{array}{l}1921 \\
2159 \\
2531 \\
2409\end{array}$ & $\begin{array}{l}57.6 \\
65 \\
76 \\
73\end{array}$ & $\begin{array}{l}\text { Turner and others, } 2009 \text {; four replicate analyses, } \\
2255 \pm 271.2 \text { average age }\end{array}$ \\
\hline DT75-72 & $\mathrm{Pk}$ & Goodnews Bay & 59.56 & 161.355 & Pyroxene granulite & $\mathrm{K} / \mathrm{Ar}$ & $\mathrm{BI}$ & $\begin{array}{l}2434 \\
2500 \\
2432 \\
2441 \\
2564\end{array}$ & $\begin{array}{l}73 \\
77 \\
73 \\
74 \\
77\end{array}$ & $\begin{array}{l}\text { Turner and others, 2009; five replicate analyses, } \\
2474 \pm 75 \text { average age }\end{array}$ \\
\hline DT75-72 & $\mathrm{ek}$ & Goodnews Bay & 59.56 & 161.355 & Pyroxene granulite & $\begin{array}{l}\text { Ar/Ar, } \\
\text { Plateau }\end{array}$ & $\mathrm{BI}$ & 2520 & & $\begin{array}{l}\text { Turner and others, } 2009 \text {; Five replicate conven- } \\
\text { tional K/Ar analyses, } 2474 \pm 75 \text { average age }\end{array}$ \\
\hline 89AJm 34 & Kkvs & Bethel & 60.056 & 159.257 & Sandstone & FT & AP & 29.7 & 4.2 & Box and others, 1993 \\
\hline 89ASb 38 & Jvs & Bethel & 60.088 & 159.269 & Sandstone & FT & AP & 90.5 & 17.0 & Box and others, 1993 \\
\hline $44-7$ & - & offshore & 58.648 & 177.215 & Basalt & $\mathrm{K} / \mathrm{Ar}$ & WR & $\begin{array}{l}.38 \\
.33\end{array}$ & $\begin{array}{l}.05 \\
.05\end{array}$ & Davis and others, $1989 ;$ mean age $0.35 \pm .05 \mathrm{Ma}$ \\
\hline $43-2$ & - & offshore & 58.648 & 177.215 & Basalt & $\mathrm{K} / \mathrm{Ar}$ & WR & $\begin{array}{l}.33 \\
.50\end{array}$ & $\begin{array}{l}.15 \\
.15\end{array}$ & Davis and others, 1989 ; mean age $0.42 \pm .15 \mathrm{Ma}$ \\
\hline $44-3$ & - & offshore & 58.648 & 177.215 & Basalt & $\mathrm{K} / \mathrm{Ar}$ & WR & .60 & .20 & Davis and others, 1989 \\
\hline DR5-34 & - & offshore & 56.383 & 169.625 & Basalt & $\mathrm{K} / \mathrm{Ar}$ & WR & .77 & .08 & $\begin{array}{l}\text { Simpson and others, 1979; Lee-Wong and } \\
\text { others, 1979. Dredge site south of St. George Is., } \\
\text { approximate location }\end{array}$ \\
\hline DR5-8 & - & offshore & 56.383 & 169.625 & Basalt & $\mathrm{K} / \mathrm{Ar}$ & WR & .84 & .08 & $\begin{array}{l}\text { Simpson and others, 1979, Lee-Wong and } \\
\text { others, 1979. Dredge site south of St. George Is., } \\
\text { approximate location }\end{array}$ \\
\hline $44-12$ & - & offshore & 58.648 & 177.215 & Basalt & $\mathrm{K} / \mathrm{Ar}$ & WR & 1.10 & .20 & Davis and others, 1989 \\
\hline
\end{tabular}

